\title{
Real estate diversification
}

Citation for published version (APA):

Eichholtz, P. M. A. (1994). Real estate diversification. [Doctoral Thesis, Maastricht University]. Rijksuniversiteit Limburg. https://doi.org/10.26481/dis.19940113pe

Document status and date:

Published: 01/01/1994

DOI:

10.26481/dis.19940113pe

Document Version:

Publisher's PDF, also known as Version of record

\section{Please check the document version of this publication:}

- A submitted manuscript is the version of the article upon submission and before peer-review. There can be important differences between the submitted version and the official published version of record.

People interested in the research are advised to contact the author for the final version of the publication, or visit the DOI to the publisher's website.

- The final author version and the galley proof are versions of the publication after peer review.

- The final published version features the final layout of the paper including the volume, issue and page numbers.

Link to publication

\footnotetext{
General rights rights.

- You may freely distribute the URL identifying the publication in the public portal. please follow below link for the End User Agreement:

www.umlib.nl/taverne-license

Take down policy

If you believe that this document breaches copyright please contact us at:

repository@maastrichtuniversity.nl

providing details and we will investigate your claim.
}

Copyright and moral rights for the publications made accessible in the public portal are retained by the authors and/or other copyright owners and it is a condition of accessing publications that users recognise and abide by the legal requirements associated with these

- Users may download and print one copy of any publication from the public portal for the purpose of private study or research.

- You may not further distribute the material or use it for any profit-making activity or commercial gain

If the publication is distributed under the terms of Article $25 \mathrm{fa}$ of the Dutch Copyright Act, indicated by the "Taverne" license above, 


\section{Real Estate Diversification}


CIP-DATA KONINKLIJKE BIBLIOTHEEK, DEN HAAG

Eichlolix, Petrus Mattheuss Alphonse

Real estate diversification / Petrus Mattheuts Alphonse

Eichtholtz. - [S.I. : s.n.]. - III., fig., tab.

Thesis Maastricht. - With ref. - With summary in Dutch. ISBN 90-9006773-6

Subject headings: real estate ; economic diversification 1 asset allocation. 


\title{
Real Estate Diversification
}

\author{
PROEFSCHRIFT
}

ter verkrijging van de graad van doctor aan de

Rijksuniversiteit Limburg te Maastricht, op gezag van de Rector Magnificus, Prof. Dr. H. Philipsen, volgens het besluit van het College van Dekanen, in het openbaar te verdedigen op donderdag, 13 januari 1994 om 16.00 uur

door

Petrus Mattheüs Alphonse Eichholtz

geboren te Bloemendaal 


\section{Promotor:}

Prof. dr. C.C.P. Wolff

\section{Co-promotor:}

Prof. dr. J.H.W. Goslings

Beoordelingscommissie:

Prof. dr. W.F.J. Buijink (Voorzitter)

Prof. dr. D.J. Hartzell

Prof. dr. C.G. Koedijk 
In loving memory of my father 



\section{Acknowledgements}

Reading the acknowledgements in a dissertation can be as tedious as reading the pages of a telephonebook, and this dissertation is probably no exception. Nevertheless, one cannot complete a dissertation without the help of others. Discussion, critique, and moral support are vital, and an opportunity to thank those who contributed cannot be missed.

First of all. I would like to thank Christian Woiff, who has stimulated me to become a scholar. He hired me, even though I wore a blinding green jacket when I first spoke to him about coming to Maastricht, and he dresses quite conservatively. My clothing habits have changed since that day, but not my respect for him. Also, I would like to thank Jan Willem Goslings, who made it possible for me to work at the ABP during the main part of my stay in Limburg, and thereby stopped me from drifting too far away from the real world. Special thanks are in order to Art Selender and Dave Hartzell. The former pllayed an important role through the courses he taught to me and my fellow $\mathrm{Ph}$.D. students. The latter encouraged me to explore the field of real estate.

This dissertation is partly based on hitherto unexplored datasets. I would like to thank Robert Boston, Nico Boxhoorn, Richard Holberton, and Mark Williams for their help in obtaining parts of these datasets. Further thanks go to Willem Buijink, David Geltner, Michael Giliberto, Jan Jager, Nathalie Jansen, Kees Koedijk, Robert Lie, Ronald Mahieu, Steven Maijoor, Fred Nieuwland, François Nissen, Peter Schotman, and Carina Wijnands. Furthermore, I wish to thank everybody in the Limburg Institute of Financial Economics and the members of the Strategic Investment Policy Group of the ABP. Also, I gratefully acknowledge financial support from the Foundation for the Promotion of Research in Economic Sciences (Ecozoek), and from the Staal Stichting 1966.

Finally, I want to thank those who contributed in a way not directly related to the content of this dissertation. My friends and family have given me joy and happiness and have thus supported my scholarly endeavors. Margo, my love, has done the same. She has not yet shared many of the spills of academic life, but that is only a matter of time, and we will have plenty of that. 



\section{Table of Contents}

Table of Contents

List of Tables

List of Figures

XIII

1 Introduction

1.1 Purpose

1.2 Outline

PART ONE

Regional Diversification

2 Economic Diversification in European Real Estate Portfolios

2.1 Relation to Previous Work

2.2 European Employment Data

2.3 Methodology: The Modified Chi-square Statistic

2.4 Economic Specialization in European Regions

2.5 Conclusions

Appendix 2.A Division of Economic Activities

According to Eurostat

Appendix 2.B1 Regional Disaggregation in Europe, Explanation of the Map

Appendix 2.B2 Regional Disaggregation in Europe 
3 Regional Economic Stability and Mortgage Default Risk in the Netherlands

3.1 Measures of Economic Diversity and Stability

3.2 Employment and Mortgage Default Data 45

3.3 Do Economic Diversity and Stability Influence Mortgage Default Risk?

3.4 Conclusions

Appendix 3.A Division of Economic Activities According to the Dutch Central Bureau of Statistics

Appendix 3.B1 The Two Levels of Regional Disaggregation in the Netherlands, Explanantion of the Map 61

Appendix 3.B2 Regional Disaggregation in the Netherlands

4 Property Shares, Appraisals and the Stockmarket: An International Perspective

4.1 The International Real Estate and Stock Data

4.2 Property Shares and the Stockmarkets 72

4.3 Property Share and Appraisal Based Returns 79

4.4 Conclusions

\section{Real Estate Diversification: By Country or by Continent?}

5.1 Property Share Data in United States Dollar Terms 88

5.2 The Continental Real Estate Factor

5.3 Methodology: Generalized Numeraire Free Principal Components Analysis

5.4 Classifying International Property Investments 101

5.5 Conclusions 
6 Are Correlations between International Property Share Returns Stable?

6.1 Data

6.2 The Stability of Correlations, Variances and Covariances

6.3 Consequenses of Instability

6.4 Conclusions

7 Summary and Suggestions for Further Research

7.1 Summary

7.2 Further Research 


\section{List of Tables}

2.1 Employment Specialization in European Regions and Countries, Results Excluding Agricultural Employment

2.2 Employment Specialization in European Regions and Countries, Results Including Agricultural Employment

3.1 Ordinary Least Squares Regressions, 30 Regions

3.2 Seemingly Unrelated Regressions, 30 Regions

3.3 Ordinary Least Squares Regressions, 12 Provinces

3.4 Seemingly Unrelated Regresions, 12 Provinces

4.1 Appraisal Based Indices

4.2 Property Share Indices

4.3 Common Stock Indices

4.4 Regression Results Property Share Returns on Common Stock Returns

4.5 Tests of the Cointegration Model $\quad 84$

4.6 Tests of Granger Causality

5.1 Property Share Indices in United States Dollar Terms 89

5.2 Exchange Rate Regimes 12 Currencies 91

5.3 Volatilities of Changes of Log Exchange Rates 92

5.4 Exports as Percentages of Total Exports to Sample Countries 95

5.5 Fit of Principal Components of Real Estate Returns, $\begin{array}{ll}\text { Locall Currency } & 103\end{array}$

5.6 Fit of Principal Components of Exchange Rate Returns 104

5.7 Fit of Principal Components of Real Estate Returns, Common Benchmark Currencies 
6.1 Datastream Property Share Indices $\quad \mathbb{1 2}$

6.2 Correlation Matrix Property Share Returns 112

6.3 Stability of the Correlation Matrix 115

$\begin{array}{ll}6.4 & \text { Stability of the Covariance Matrix } \\ 6.5 & 115\end{array}$

6.5 Stability of the Variances 116

\section{List of Figures}

2.1 Regional Economic Specialization Excluding Agricultural Employment

2.2 Regional Economic Specialization Including Agricultural Employment

4.1 Property Shares versus the Stock Market: France

4.2 Property Shares versus the Stock Market: Switzerland 74

4.3 Property Shares versus the Stock Market: United Kingdom 75

4.4 Property Shares versus the Stock Market: Hong Kong 75

4.5 Property Shares versus the Stock Market: Japan 76

4.6 Property Shares versus the Stock Market: Canada 76

4.7 Property Shares versus Appraisals: United Kingdom 81

4.8 Property Shares versus Appraisals: Hong Kong 81

4.9 Property Shares versus Appraisals: Canada $\quad 82$

4.10 Property Shares versus Appraisals: United States 82

5.1 Japan and the Second Component 



\section{Chapter 1 \\ Introduction}

Real estate is what distinguishes sedentary man from the nomad. Around 9000 B.C. man stopped wandering and changed land into real estate. Cereal cultivation in the lowlands of the Near East in the ninth millennium B.C. produced for the first time communities large enough to develop brick and stone architecture for both public and private buildings (Barraclough and Stone, 1989). Their remains still exist, indicating the long term nature of real estate as an asset class. The foundation of Jericho, between 8350 and 7350 B.C., was the next main event in the history of world real estate. It was the first walled town in the world, covering an area of about 4 hectares, and inhabiting between 2,000 and 3,000 persons (Encyclopedia Britannica, 1991). Catal Hüyük, in its turn was founded around 6250 B.C. in Anatolia (central Turkey) and soon became the largest town in the world, covering an area of about 13 hectares. Meanwhile, around 7000 B.C. in North West China, the town of Pan-p'o-ts'un was founded, completely independent of the developments in the Near East. From 3000 B.C. onwards, the first settlements properly called cities were developed in Sumer (Southern Mesopotamia) by the Sumerians, who originally came from Anatolia. Their first capital was Kish.

And such was the birth of an asset which has intermittently flourished and withered ever since. For centuries, it has made many people rich and others poor, and consequently has attracted a great deal of attention from all quarters, only recently including academics. Nevertheless, real estate, contrary to stocks and bonds, is an investment vehicle still largely shrouded in veils. Stock and bond investments have been unveiled since the emergence of modern finance, see Nieuwland (1993) for an excellent overview, but in real estate research many avenues are as yet unexplored. Nevertheless, cross fertilization between finance and real estate is already changing the field substantially. The lightning move from descriptive discipline to analytical rigor that radically changed finance is also changing real estate.

In finance, computer power, combined with abundant financial data of high quality led to a revolution in the research of the behavior of security prices. The 
results of this revolution in finance have influenced the state of the art in real estate as well. Hirshleifers' (1958) treatment of the net present value rule is the first example. It has directly influenced valuation techniques for real estate. The Modern Portfolio Theory as developed by Markowitz (1952, 1959) and Tobin (1958), the Capital Asset Pricing Model (CAPM) of Sharpe (1964) and Lintner (1965), and the Arbitrage Pricing Theory of Ross (1976) were all developed to explain security prices and have all been used in real estate finance as well, with varying degrees of success. The developments in option pricing that started with Black and Scholes (1973) have also proved important in real estate finance, especially in mortgage pricing. In fact, it is the adoption of techniques developed in finance that lead to the start of modern real estate. As Miles and Hartzell (1988) put it:

"The modern era of real estate dawned with the work of [...] Roger Ibbotson. In 1979 he published the first of what was to become a series entitled "The World Wealth and the US Wealth Portfolios". [...] A well known stock and bond data producer had chosen to show real estate on equal footing with stocks and bonds."

Traditionally, the real estate field leaned heavily on urban and regional economics. In modern real estate, finance is the main influence and real estate has been partly changed into real estate finance. This does not imply that the link with urban and regional economics is no longer existent. Two separate markets for real estate exist: the market for space, and the market for real estate as an investment asset. In our understanding of the former, urban and regional economics play a major role (See Harvey, 1987). The contributions of finance to the field have mainly generated insights concerning the market for real estate as an investment asset, which is also the focus of this study.

As much as finance has contributed to real estate, however, the two disciplines differ at least in one critical aspect. Finance has a paradigm that ties together in one unifying theory both the traditional investment and portfolio decisions of individuals and the traditional corporate finance issues. This has changed finance into financial economics (Hamada et al., 1988). Real estate finance, on the other hand, is a field in search of a paradigm. The fundamental question is whether real estate assets are essentially different from other assets. If they are, 
then the standard asset pricing models do not apply and special real estate pricing models have to be developed. On the other hand, if real estate assets are not different, then alternative asset pricing models are not needed, and the finance paradigm applies.

Lusht (1988) concludes, based on a survey of the existing literature, that real estate indeed differs fundamentally from other assets, and that the available pricing modells are not up to the task of pricing real estate. This conclusion is mainly based on the fact that existing asset pricing models cannot explain the high return of real estate relative to its risk. Real estate's stockmarket beta is usually found to be very small. Geltner (1989b), tries to resolve this risk/return puzzle by applying the consumption oriented Capital Asset Pricing Model of Breeden (1979) to real estate. He uses the appraisal based returns on incomeproducing real estate. Although he finds real estate's stockmarket beta to be extremely small, he also finds a significant real estate consumption beta. This suggests that a real estate pricing model using consumption might explain the magnitude of real estate returns relative to their risk.

Liiu, Grissom and Hartzell (1990) complement the work of Geltner by including owner occupied housing in the analysis. They modify the CAPM to incorporate some special factors applicable to real estate: costly information, transactions costs associated with selling real estate, and a mildly segmented housing market, in which only households can purchase owner-occupied housing. Modified versions of the CAPM are then constructed for corporate stocks, owner-occupied housing, and investment real estate. Their main finding is that systematic mispricing of real estate will occur if the unaltered pricing model for financial assets is applied to real estate. The expected excess return on investment real estate they find exceeds the market risk premium by a liquidity premium, which is inversely related to the size of the cash flow component of the property. Beta is still the measure of systematic risk, but the risk premium associated with it is a function of the degree to which asset markets are segmented.

Chan, Hendershott and Sanders (1990) employ both the CAPM and a multifactor Arbitrage Pricing Theory (APT) model with prespecified macroeconomic factors to investigate the risk-return puzzle in real estate. They find excess risk-adjusted returns when the single factor CAPM is applied to the returns of property shares, i.e. the shares of companies which hold a portfolio 
of real estate investments as assets. On the other hand, when employing a five factor APT model, these excess returns disappear. Both common stock and property share returns are consistently explained by the term structure of interest rates, a default risk premium, and unexpected inflation. Real estate is found to be less risky than stocks.

These results lead us to infer that Lusht's 1988 conclusions were premature, and that asset pricing models developed in financial economics, albeit modified, can be used for the pricing of real estate. Before concluding, however, that the financial economics paradigm can be applied to real estate markets, it is important to look first at another major building block of that paradigm: the efficient markets hypothesis of Fama (1970). Various studies have addressed the question whether real estate markets are efficient. In a review article, Gau (1987) argues that the concept of efficient real estate markets should be the working paradigm of real estate research and analysis. At first sight, this is surprising. Especially among real estate practitioners the consensus seems to be that real estate investors can exploit market imperfections to earn consistently abnormal risk-adjusted returns. Indeed, it is likely that real estate markets are generally less efficient than financial markets, like stock and bond markets. On the latter markets, information is freely and abundantly available, transactions costs are low, and traded assets are homogeneous and divisible. All this does not hold for the real estate markets. Transactions are mostly concluded in secret, transactions costs are high, and the assets are lumpy and not homogeneous. Furthermore, it is likely that some real estate markets are not as efficient as others. On the housing market, for example, many transactions occur which are not based on financial reasons alone. This could lead to mispricing of houses. However that may be, the issue is not whether real estate markets are perfectly efficient, but whether they are efficient enough for the efficient market hypothesis to be an effective framework for analysis. After all, financial markets are not perfectly efficient, but the efficient market hypothesis has proved very successful and its adoption has lead to innumerable new insights. Thus, we have an empirical question. Is new information generally reflected fully and immediately into real estate values and is it impossible to earn abnormal returns based on this information?

Most research in this field concerns residential real estate. Gau (1985) and Gau and Wicks (1982) investigate the effect of changes in government policy on the prices of apartments. These studies find an absence of abnormal returns and no 
evidence that real estate investors can utilize publicly available information to earn higher returns on a risk-adjusted basis. Other studies investigating the efficiency of the residential real estate markets are Linneman (1986), Guntermann and Smith (1987), Rayburn, Devaney and Evans (1987), Case and Shiller (1989, 1990), and Guntermann and Norrbin (1991). These studies generally find some evidence of market inefficiency but typically conclude that profitable trading rules or strategies exploring these inefficiencies cannot be developed because of high transaction or information costs or because of the difficulty of accurately forecasting real estate prices. McIntosh and Henderson (1989) examine the efficiency of the office properties market. They investigate whether investors can profit from knowing or analyzing past prices. The authors conclude that they cannot. Finally, Darrat and Glascock (1993) examine whether the market for publicly listed real estate stocks is efficient. Their results suggest that movements in key economic variables are quickly and fully utilized by market agents. On the other hand, the relationship between real estate returns and fiscal policy changes is lagged, but the authors do not find profitable trading strategies based on that phenomenon.

These empirical results suggest that real estate markets are not completely efficient, but that trading strategies based on these inefficiencies do not generate consistent excess returns net of transactions costs. This suggests that real estate markets are efficient enough to use the efficient market hypothesis successfully. Combined with the earlier reviewed results of asset pricing models, this implies that the financial economics paradigm can indeed be applied to real estate markets, and that a separate real estate finance paradigm is not required. This does not mean real estate completely satisfies this paradigm, but that is not a prerequisite. As noted by Kuhn (1970, 17-18):

\footnotetext{
"To be accepted as a paradigm, a theory must seem better than its competitors, but it need not, and in fact never does, explain all facts with which it can be confronted."
}

All in all, finance and real estate have a lot in common, not only scientifically, but also in their practical relevance. Finance theory has had a direct influence on finance practice (Merton, 1990), and likewise academic research in the field of real estate finance has a direct impact on reall estate practice. This is especially true in the area of mortgages, but also in areas like portfolio 
selection, risk analysis and valuation. The practical relevance of academic research in real estate finance is also central to this study. Before going on to the outline of the dissertation, we will now give a brief introduction in its main subject: diversification.

\subsection{Purpose}

If the financial economics paradigm applies to real estate, one of the main consequences is that you can't beat the market. In that case, the added value of an expert over the proverbial ape throwing darts at the financial pages of the Wall Street Journal is in diversification. Real estate has always been a very property specific business, and the question how individual properties fit into a portfolio has had attention only recently. The theoretical reasons why diversification works for stocks and bonds also hold for real estate, but due to the lack of real estate returns data, the theories have only recently been tested for real estate. The literature on this subject has focused on the role of real estate in mixed asset portfolios and on the risk reduction potential of diversification within the real estate portfolio. Friedman (1970) is the first example of the former. Others are Webb and Rubens $(1986,1988)$, and Firstenberg, Ross and Zisler (1988). These studies invariably find that real estate reduces the variability of mixed asset portfolios and should consequently have a major weight in these portfolios. This result can to a great extent be attributed to the use of appraisal based returns data for real estate. These returns are smoothed, and their resulting low variance at least partly accounts for the large weight of real estate in portfolio compositions based on asset allocation models. The smoothing can probably allso be credited for the low correlation of the appraisal based returns with other asset returns. If the returns used are based on transactions, for example the returns of property shares, the diversification potential of real estate appears to be limited (Mengden and Hartzell, 1986). These returns have variances that are far higher than the variances of appraisal based returns and, furthermore, they are highly correlated with the returns on other assets, particularly stocks.

Since the debate as to which type of real estate returns data are appropriate has not been concluded yet, the use of asset allocation models to determine the optimal allocation to real estate in a mixed asset portfolio is dubious. Recently, therefore, research has focused on calculating the total value of real estate in a 
country. This value is then combined with the value of other assets to get the composition of the total market portfolio, which equals the optimal allocation to real estate and other assets. After all, the market portfolio is the optimally diversified portfolio. The first research along these lines was performed by Ibbotson and Fall (1979). More recent examples are for the United States, Miles et al. (1991), and Hartzell, Pittman and Downs (1992). For the Netherlands, Eichholtz and Tates (1993) have made similar calculations. These studies find the value of commercial real estate to be between 5 and $20 \%$ of total investment assets.

Diversification within the real estate portfolio has also received attention in the literature. A number of authors have examined the gains in risk reduction associated with diversification of real estate, either across geographical region or property type. Firstenberg, Ross and Zisler (1988) find that real estate returns of different regions and property types are weakly correlated, and that diversification can lead to substantial risk reduction. Hartzell, Hekman and Miles (1986), and Grissom, Kuhle and Walther (1987) find that real estate diversification, especially across property types, is even more effective in reducing portfolio variance than diversification of stock portfolios. However, effective as real estate diversification may be, determining the optimal composition of the real estate portfolio is difficult due to the caveat with respect to the data we described before.

To this problem, two solutions have been applied. The first is analogous to the one described above for mixed asset portfolios. Miles et al. (1991), and Hartzell, Pittman and Downs (1992) attempt to determine the values of the components of the real estate portfolio. They estimate the values of retail, office and industry property in the largest metropolitan areas in the United States. The values they find can be used as input to obtain the optimal allocation within the United States real estate portfolio.

The other solution involves an analysis of the economic characteristics of regions to determine the optimal geographical allocation of a real estate portfolio. This type of analysis uses insights developed in the regional and urban economics literature. The basic idea is that returns on real estate in regions which share the same economic characteristics show a positive correlation. A well diversified real estate portfolio should therefore include assets from regions with different economic characteristics (See Wurtzebach and 
Miles, 1991, Chapters 2 and 22). The main examples of research in this direction are Hartzell, Shulman and Wurtzebach (1987), and Shulman and Hopkins (1988). The former classify regions in the United States based on cultural, economic and location-oriented homogeneity. They could test geographic diversification strategies based on this classification and concluded that the results were more efficient than those of naive regional diversification. Shulman and Hopkins analyze regions in the United States based on their employment concentrations. They form portfolios of regions with the same specialization. The main contribution of their research is the movement away from analyzing geographically contiguous regions to defining regions characterized by homogeneous economies. Although they do not formally test whether this method leads to more efficient diversification, their argument is intuitively appealing. In this dissertation, we study real estate diversification along these lines in Part One.

The international aspects of real estate diversification have received less attention in the literature, mainly due to lack of data. Sweeney (1989) determines the optimal international real estate allocation for a British investor by using a Markowitz type approach. She uses international rental growth rates as a basis for her analysis. Giliberto (1990a) and Giliberto and Testa (1990) use the returns on property shares from different countries to determine the influence of international diversification on the risk of the real estate portfolio of an American investor. Gordon (1992) calculates efficient frontiers for real estate investments in the United States and the United Kingdom. As inputs for his portfolio model he uses appraisal based returns indices. All four studies find that real estate returns in different countries are weakly correlated and that international diversification can lower real estate portfolio risk. Consequently, they find that portfolio allocations to international real estate are substantial regardless whether the investor is British or American. Asabere, Kleiman and McGowan (1991) investigate for an American mixed asset portfolio the gain from international diversification of real estate. They conclude that portfolio performance is improved when including international real estate stocks in the portfolio. Ziobrowski and Curcio (1991) approach the subject of international diversification from the other side: they investigate diversification benefits of United States real estate to foreign investors. Their results indicate that United States real estate does not improve foreign portfolio performance, but this is mainly due to adverse exchange rate fluctuations in their sample period. Finally, Grauer and Hakansson (1992) compare portfolio risk and return of stock and 
bond portfolios with and without reall estate, both in the United States and in a global setting. They find the gains from adding real estate to the universe of United States financial assets to be significant, but the gains from adding United States and international real estate to a universe of global financial assets are mixed.

The aim of this dissertation is to investigate real estate diversification in greater depth than has been the case sofar. The focus is on international diversification within the real estate portfolio, and the nature of the dissertation is empirical. Generally, in empirical research, originality can be achieved either by using new data or by using new methodology. In financial economics, datasets like the CRSP security price data have been examined by so many that originality can only emanate from the methodology used. It is therefore not surprising that methodologies in financial economics have become so complex. In real estate economics, data is still crucial to originality, and analytical and statistical methods are still relatively straightforward. In this dissertation, the exploration of hitherto unexplored data is one of the central tenets. In addition, particularly in Chapter 5, some methodology contributions are made.

\subsection{Outline}

This dissertation has three parts. Part One is about regional diversification of real estate portfolios and includes Chapters 2 and 3; Part Two is devoted to international diversification of real estate portfolios and includes Chapters 4 through 6. Part Three concludes the dissertation and includes Chapter 7.

In Part One, the link between real estate on the one hand and regional economics on the other hand is central. Chapter 2 deals with economic diversification in European real estate portfolios. Due to lack of regional real estate returns data, it is not clear exactly how to diversify within the real estate portfolio. In this chapter we circumvent this lack of data by using regional employment characteristics. Making an implicit demand side connection to the real estate markets, this approach allows us to obtain insight into economic diversification possibilities in European real estate portfolios. We apply a modified chi-square technique to employment shares in 74 European regions. We find regions with a common economic specialization to be scattered over Europe. This implies that regionally diverse investments are not necessarily 
economically diverse. Also, we find many regions to be internally diverse, which means that it is not always necessary to diversify regionally in order to obtain optimal risk reduction of the real estate portfolio.

The demand side connection between real estate markets and employment we have assumed in Chapter 2 is formally tested in Chapter 3 . In this chapter we investigate the relationship between regional economic diversification and stability, and residential mortgage default risk. To describe and measure regional economic diversity and stability, methods from both the regional economics and the industrial economics literature are used. All measures are based on regional employment characteristics. Mortgage default rates are obtained from a database of the population of insured mortgage defaults in the Netherlands from 1983 through 1990 . To test the relationship between the measures and mortgage default risk, we use cross sectional Ordinary Least Squares regression and Seemingly Unrelated Regression. We find that the employed measures explain regional mortgage default rates to a significant extent, and that stability measures outperform diversity measures.

Part Two contains three chapters, which are all concerned with international real estate diversification and all use international property share returns data. In this part of the dissertation, the link between real estate and financial economics is important. In Chapter 4, we investigate for twelve countries the relationship of property shares with the stock markets on which they trade. For four of these countries, we also investigate the relationship of property share returns with appraisal based returns using error correction or cointegration models. Our results indicate that property shares are closely related to the stockmarkets on which they trade, thus confirming previous results for the United States. Yet, property share returns also significantly predict appraisalbased returns.

In Chapter 5 we examine whether a continental factor in real estate returns exists. To this end, we develop a numeraire independent form of principal component analysis, which is subsequently used to see if real estate returns across countries within a continent move together. The methodology is applied on return indices of property shares for twelve countries from three continents. The findings indicate that real estate returns for countries within a continent indeed show common movements. This implies that investors cannot achieve optimal international real estate diversification by investing in only one 
continent. To achieve this, a truly global scope is needed.

In Chapter 6, we investigate the variance-covariance structure of international property share returns. This structure is a critical input to portfolio models used to generate the optimal allocation of international real estate investments. Usually, realized variances and covariances are used in these modells. However, if the variance-covariance structure of property share returns is not stable in time, inferences drawn from realized returns do not yield results on which reliable asset allocation decisions can be based. In this chapter, we inquire into this stability. We find variances and covariances of international property share returns to be unstable, while correlations are stable between some time periods, and unstable between others. This finding casts doubt on the use of portfolio models to generate efficiently diversified international property share portfolios.

Part Three includes only Chapter 7 , in which we give an overview of the key findings of the five empirical chapters of the study. Besides the scientific relevance of these findings, we focus on their practical implications. The second goal of this last chapter is to suggest directions for a future research agenda in the field of real estate diversification. Especially the international aspects of real estate diversification have hardly received attention in the literature. 



\section{PART ONE}

\section{Regional Diversification}





\section{Chapter 2 \\ Economic Diversification in European Real Estate Portfolios}

Pension funds and other institutional investors have long accepted a role for domestic real estate in their portfolios. Several studies - see for example Hartzell (1986), Ross and Zisler (1991) and Giliberto (1992) - have come to the conclusion that pension funds should hold between $5 \%$ and $15 \%$ of their portfolios in their domestic real estate market, primarily for diversification reasons, but also as an inflation hedge and for superior return performance in certain periods.

Real estate thus has a recognized role in mixed-asset portfolios. Several studies have gone on to examine how the real estate portfolio should itself be diversified. Two classifications have generally been used in the analysis of diversification within the domestic real estate portfollio: diversification by property type and by geographic region. This chapter focuses on the latter classification. In general, the professional and academic literature supports economic, rather than purely geographical, diversification - see Hartzell, Shulman and Wurtzebach (1987) and Shulman and Hopkins (1988). Instead of merely separating the country into geographical segments, these economic diversification studies analyze the basic economic components of regions to determine efficient diversification strategies. Typically, these studies focus on employment as a classifying variable, making an implicit demand side connection to the real estate market. Although there have been no tests of portfolio performance using these categories and property-specific return data, the intuition behind the approach is appealing.

Given the acceptance of domestic real estate by U.S. institutional investors, several investment managers have recently been making the case for U.S. pension fund investment in European real estate. For example, Gordon (1991) outlines several reasons for expanding into global real estate markets. These include the fact that the "capitalized value of commercial properties in the major cities of Europe is roughly equivalent to that of income-producing property in North America." Further arguments made by Gordon include the higher returns 
from European properties, as compared to U.S. property, over the last five years, the general lack of overbuilding in most European markets, the changing economic relationships among cities given the economic integration of Europe in 1993, and the fact that European property returns do not appear to be correlated to U.S. property returns. Wurtzebach (1991) gives simillar reasons for holding a global real estate portfolio.

Unfortunately there are no returns data for a general European real estate portfolio, so it is difficult to analyze the performance characteristics of investment property in Europe or to compare it to the U.S. However, it seems clear that with investment managers currently promoting pension fund interest in European portfolios, global real estate investment is on the rise.

Since investor interest in European real estate markets is increasing, the question arises how the European reall estate portfolio should be diversified. Research to date has simply divided Western Europe into twelve regions: the twelve countries. The underlying assumption is that an investor can achieve diversification benefits by including property from different countries. This is very much like the investor who 'diversifies' across the four regions of the United States: East, Midwest, West and South. In 1993 in Europe however, this seems to be a strategy of the past. Although the unification of Europe is currently stalling, it seems preferable to analyze Europe as a whole, and to divide it into regions which share basic economic characteristics. This analysis can assist investors in selecting a truly economically, as opposed to geographically, diversified real estate portfolio.

The logic behind this approach is that regions which share basic economic characteristics show correlated employment figures. Through the demand side of the real estate markets, real estate returns of these regions are therefore likely to be correlated also, particularly if the supply situation in the regions is similar. On the other hand, real estate returns of regions that do not share basic economic characteristics probably have low or even negative correlations, for at any given time, these returns would be influenced by different economic developments. This makes it logical that risk reduction within the real estate portfolio can be achieved more efficiently through diversification by economic area than through naïve regional diversification.

This chapter provides a regional analysis of Europe based on economic factors. 
The regions are distinguished on the basis of their dominant employment sectors, using an industrial classification applied in Europe which is similar to the Standard Industrial Codes used for classification of employment and income statistics in the United States. Section 2.1 of this chapter relates the present research to work previously done in the United States. Section 2.2 details the data base used in this study, while Section 2.3 discusses the methodology employed to identify dominant employment sectors in each region. Section 2.4 presents the results of the classification analysis by identifying dominant sectors within the 74 regions and Section 2.5 concludes the chapter.

\subsection{Relation to Previous Work}

Hartzell, Hekman and Miles (1986) were among the first to obtain sufficient data to analyze the concept of regional diversification of real estate portfolios. Using property-specific data provided by a large commingled real estate fund, they separated the United States real estate portfolio into four broad regional sub-portfolios: East, Midwest, West and South. They found that the returns earned by portfolios in each of these regions generally exhibited low correlations, but that the classifications were probably too broad to be used for detailed diversification strategies. They made a call for "more exacting" classifications of regional diversification.

Hartzell, Shulman and Wurtzebach (1987) used an updated version of the same data base to construct new regional classifications based on notions of cultural, economic and location-oriented homogeneity. They divided the U.S. into eight regions: Mid-Atllantic; New England; Old South; Industrial Midwest; Farmbelt; Mineral Extraction; Southern California; and Northern California. The underlying theme of their paper derives from Garreau (1985). They concluded that this more detailed regional classification is more appropriate for institutional real estate investors, since the correlations between the eight regions are lower than were found in the four-region analysis. Therefore, investors following the eightregion strategy would have been able to obtain a better risk-adjusted return than those who continued naively to diversify across four regions.

Shulman and Hopkins (1988) analyze 60 Metropolitan Statistical Areas (MSAs) based on the dominant employment concentrations within those areas. They then classify MSAs which have similar employment characteristics into homogeneous 
"portfolios". Their main contribution is to extend the movement away from analyzing geographically adjacent regions to defining regions dominated by homogeneous economics. They identify seventeen different industrial categories and construct "portfolios" of MSAs which fall within each of them. While there have been no empirical tests of real estate returns based on these economic classifications, the authors conclude that economic diversification is likely to be superior to four-region and eight-region diversification strategies.

In this study, a concept similar to that of Shulman and Hopkins is applied to Europe, to isolate regions which would be expected to respond to similar economic stimuli. Using detailed regional data on sectoral employment and a statistical analysis, we find the dominant industrial sectors within each of the regions in Europe. These regions are not adjacent, allowing portfolios to be constructed based on the concept of economic diversification. The resulting analysis will be useful to pension funds and other institutional investors which are currently exposed to the European real estate market, and also for U.S. institutional investors who have, or will decide to gain, exposure in Europe, and who are interested in a first look at how the portfolio should be diversified.

\subsection{European Employment Data}

Employment data provided by Eurostat in Luxembourg is used as the basis for our European employment categories. In the past, employment statistics have been difficult to obtain because of the lack of uniformity in the classifications used, and the unavailability in many countries of adequate time series of official employment statistics. Unlike the United States, there is no "employment tape" for Europe, so constructing an adequate data base is quite difficult. Eurostat, however, annually surveys a total of some 600,000 households in twelve countries of Europe to determine the characteristics of the labor force. Experience with previous surveys has shown that at national level the survey information provides sufficiently accurate estimates for the principal aggregates into which the labor force is divided. Detailed classifications, however, and results at regional levels, may be affected by considerable sampling errors (Eurostat, 1990). Thus, a trade-off exists between detail and reliability, and it is important to choose the proper mix between the two. Eurostat combines the data into eleven industrial sectors at three levels of geographical disaggregation. For reference, the sectoral classifications are shown in Appendix 2.A. 
Eurostat uses three levels of regional disaggregation. The first geographic level divides the employment in each sector over the twelve countries. The second level further breaks the data down into the 74 commonly recognized regions in Europe, which are employed as the basis for the current research. Details of the 74 regions and the largest cities within each of them are presented in Appendix 2.B, along with a map showing the locations of each of the regions. A finer disaggregation separates the twelve countries into 145 regions. We do not use this data, since using it would increase the risk of sampling errors, while not adding much to the informational content of this study.

We use data from the 1988 Labour Force Survey ${ }^{1}$. For some countries in the European Community, for example in the Netherlands, labor force statistics of more detail, completeness, and reliability exist. These, however, are normally not comparable among counties, which is of key importance to this study. The degree of comparability of the Community survey results is considerably greater than that of any other existing set of statistics on employment from Member States of the European Community. This is principally due to the use of the same definitions and classifications, the synchronization of the survey, and the central processing of the data (Eurostat, 1990).

\subsection{Methodology: The Modified Chi-square Statistic}

The 74 regions are classified according to the employment category which is dominant within each region. Data for each of the eleven industrial sectors outlined in Appendix 2.A is available for each of the regions. A specialized region is defined as one in which the employment share in one or more sectors is significantly higher than the European average share in that sector ${ }^{2}$. To specify which of the eleven sectors is dominant, a straightforward chi-square approach is employed to each economic sector of each region, where a sector's actual share of employment in a region is the observed variable, and its share in Europe as a whole is the expected frequency. From a standard chi-square test

1 The most recent year available when this chapter was written.

2 The chance of finding more than one dominant sector in a region is small: If many people work in one dominant sector, there are less people left to work in the other sectors. 
statistic,

$$
\chi_{r}^{2}=\frac{\left(S_{i r}-S_{i e}\right)^{2}}{S_{i e}}
$$

where $S_{i r}$ is the employment share of sector $i$ in region $r$, and $S_{i e}$ is the employment share of sector $i$ in Europe as a whole, it cannot be concluded that the sector share of employment in a region is over or under' the European average since the chi-square statistic is always positive. Therefore, the statistic is multiplied by

$$
\frac{S_{i r}-S_{i e}}{\left|S_{i r}-S_{i e}\right|}
$$

to get

$$
\chi_{r \bmod }^{2}=\frac{\left(S_{i r}-S_{i e}\right)^{3}}{S_{i e}\left|S_{i r}-S_{i e}\right|}
$$

The modified chi-square statistic is calculated for each sector in each region. If a sector's share of employment in a region is higher than the European average, the calculated statistic will be high and positive. Since we are interested in classifying regions on the basis of their economic specializations, only high positive values of the modified chi-square statistic are considered. Each region is classified according to the sector having the highest modified chi-square value. If a region does not have a significant and positive statistic in any sector, then employment does not significantly diverge, in any sector, from the sector's share in Europe as a whole, and the region is classified as diversified.

\subsection{Economic Specialization in European Regions}

The results are presented here in two parts. The first part, as with Shulman and Hopkins (1987), reports the specialization categories based on all non-agricultural employment. Since institutional investors are interested primarily in income producing property, employment categories which are relevant for office, industrial, retail, and hotel properties are most relevant. Therefore, 
agricultural employment is often excluded from analyses in the literature, as it is in this first part of our analysis. However, unlike Shulman and Hopkins, we also perform the analysis including agricultural employment, since we also want to look at the structure of regional economies as a whole, and furthermore, especially in many regions in southern Europe, agriculture is the largest economic sector, employing up to $25 \%$ of the working population. Even if no direct link between agricultural employment and property returns exist, the importance of agricultural employment in those regions will be also felt in the real estate markets. As we will see in the rest of this section, the inclusion of agricultural employment causes many of the specialization classifications to change.

\section{Results Excluding Agricultural Employment}

The results of the chi-square analysis for all non-agricultural employment are presented in Table 2.1. For the chi-square statistics presented, significance at the $90 \%$ level with one degree of freedom is achieved at a chi-square of 2.71 ; at the $95 \%$ level, the relevant chi-square statistic is 3.84 ; and $99 \%$ significance is achieved at a chi-square value of 6.64 .

In general, most of the results from Table 2.1 are consistent with casual observation and expectations regarding employment concentrations in several regions. Of course, these findings are general in nature, but serve as a first step in analyzing the strategic diversification of real estate portfolios. In making particular property investments, attention must be paid to the type of tenant and the industrial diversification of tenants within a building.

It is no surprise that employment in the regions which include the cities of London (South East), Paris (Ile de France), Amsterdam and Rotterdam (West Netherlands), and Brussels (Brussels) is heavily concentrated in the finance, insurance and real estate (FIRE) sector. Investors who invested primarily in property in these regions would be highly exposed to fluctuations in this sector, even though the regions are geographically diverse. Similarly, in several regions of Germany there are significant concentrations in metal manufacturing (steel, autos, etc.), much like the concentration in the midwestern United States. For example, BMW and Mercedes plants are located in Stuttgart (Baden Wurttenburg), which specializes in metal manufacturing Several other regions in Germany and in Spain are also concentrated in this industry. 
Table 2.1: Eimplloyment Specialization in European Regions, Resullis Excluding Agricultural Employment.

\begin{tabular}{|c|c|c|c|}
\hline Country & Region & Specialization & Chi-square Value \\
\hline United & Kingdom & Diversified & \\
\hline & North & Energy & 3.68 \\
\hline & Yorkshire & Diversified & \\
\hline$\because$ & East Midlands & Diversified & \\
\hline & East Anglin & Diversified & \\
\hline & South East & Finance, Insurance \& Real Estate & 7.28 \\
\hline & South West & Diversified & \\
\hline & West Midllands & Metal Manufacturing & 4.50 \\
\hline & North West & Diversified & \\
\hline & Wales & Diversified & \\
\hline & Scotlland & Diversified & \\
\hline & North Ireland & Diversified & 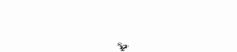 \\
\hline Netherlat & ands & Diversified & \\
\hline & North & Other services & 3.61 \\
\hline & East & Other services & 2.72 \\
\hline & West & Finance, Insurance \& Real Estate & 3.45 \\
\hline & South & Diversified & \\
\hline Belgium & & Diversified & \\
\hline & Vlaanderen & Diversified & \\
\hline & Wallonie & Diversified & \\
\hline & Bruxelles & Finance, Insurance \& Real Estate & 5.19 \\
\hline France & & Diversified & \\
\hline & Ile de France & Finance, Insurance \& Real Estate & 8.15 \\
\hline & Bassin Parislien & Diversified & \\
\hline & North-Pas de Calais & Diversified & \\
\hline & East & Diversified & \\
\hline & West & Diversified & \\
\hline & South West & Diversified & \\
\hline & Central East & Diversified & \\
\hline & Mediterrinde & Diversified & \\
\hline Germany & & Metal Manufacturing & 3.81 \\
\hline & Schleswig Holstein & Commercial Services & 8.31 \\
\hline & Hamburg & Transport \& Communication & 4.09 \\
\hline & Niedersachsen & Diversified & \\
\hline & Bremen & Transport \& Communication & 3.57 \\
\hline & Nordrhein-Westfalen & Metal Manufacturing & 3.61 \\
\hline & Hassen & Diversified & \\
\hline & Rheinland-Pfalz & Mining & 10.05 \\
\hline & Baden-Württemberg & Metal Manufacturing & 15.12 \\
\hline & Bayern & Metal Manufacturing & 5.61 \\
\hline & Sasrland & Energy & 13.65 \\
\hline & Berlin West & Diversified & \\
\hline
\end{tabular}

Note: Significance at the $90 \%, 95 \%$, and $99 \%$ levels is at $2.71,3.84$, and 6.64 , respectivelly. 
Table 2.1: Employment Specialization in European Regions,

Results Excluding Agricultural Employment (Continued).

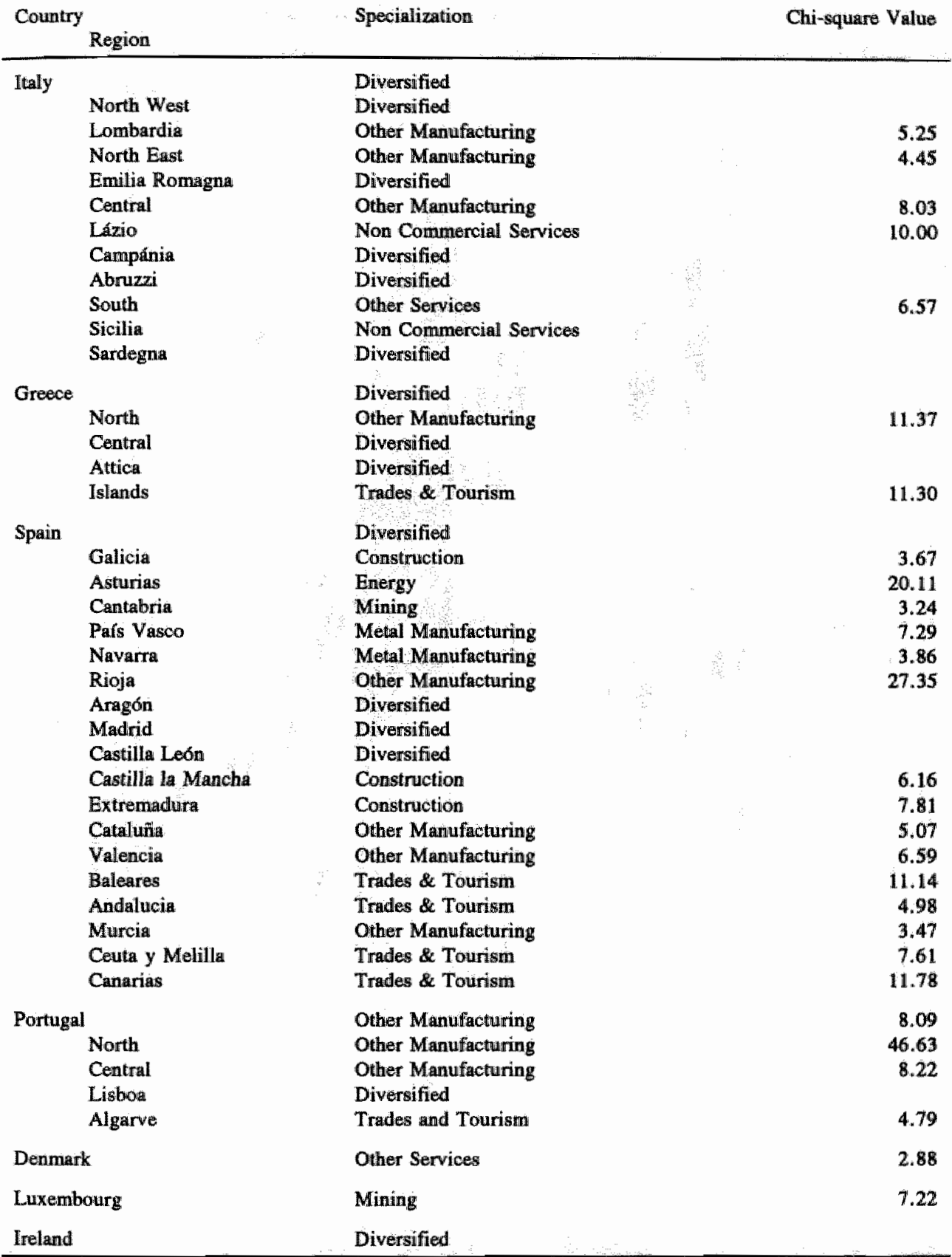


Figure 2.1

Regional Economic Specialization

Excluding Agricultural Employment

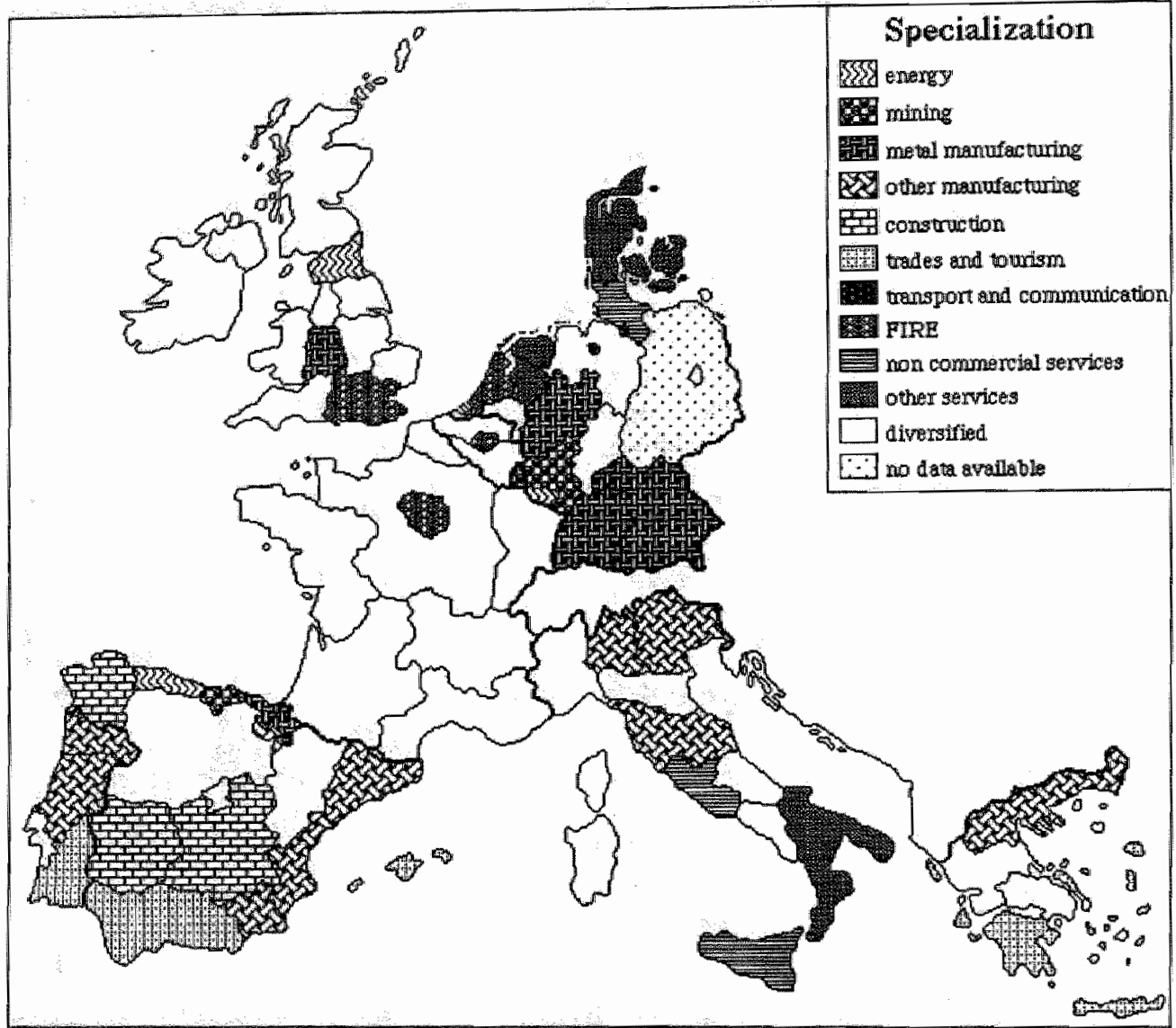


Regions which are heavily dominated by non-commercial services include Lazio, in Italy, Ceuta y Melilla in Spain and Schleswig Holstein in Germany. That only the first of these contains a capital city (Rome) is surprising since this sector includes government services. Perhaps another surprising result is the mining dominance in Luxembourg. While the city of Luxembourg is home to many corporations, they are largely shells created for tax purposes which employ few people. Most of the country outside of Luxembourg city is involved in mining operations.

Trades and tourism dominate in the areas along the Mediterranean Sea, which include the Canary Islands and the Greek islands, and also in the Algarve region in Portugal and the Andalucia region in southern Spain. It is interesting to note that most of these areas also have construction sectors which significantly deviate from the European average. This may be a short-term phenomenon as hotels and other facilities are built to accommodate tourists.

The measures of specialization are also calculated for the 12 countries. Excluding agricultural employment, only four countries have significantly specialized employment concentrations. In keeping with the regional findings, overall German employment is significantly concentrated in the metal manufacturing industries. Similarly, Luxembourg is specialized in mining for reasons given above. Employment in Portugal and Denmark is also concentrated, in 'other manufacturing' and 'other services', respectively. All of the other countries in Europe have what can be considered diversified employment bases.

A graphical summary of the regional non-agricultural employment specialization findings is presented in Figure 2.1, which maps the regions according to their dominant employment categories. As was mentioned above, there are finance, insurance \& and real estate concentrations in regions in four different countries. Similarly, an investor could hold properties in Eastern Spain, Portugal, Northern Greece and Northern Italy and still be strongly subjected to factors affecting industries in the 'other manufacturing' sector. Some 42 of the 74 regions are diversified, as defined above. Investment in these regions would be less subject to industry-specific effects.

\section{Results Including Agricultural Employment}

When the agricultural sector is included in the analysis, many of the regions 
Table 2.2: Employment Specialization in European Regions, Results Including Agricultural Employment.

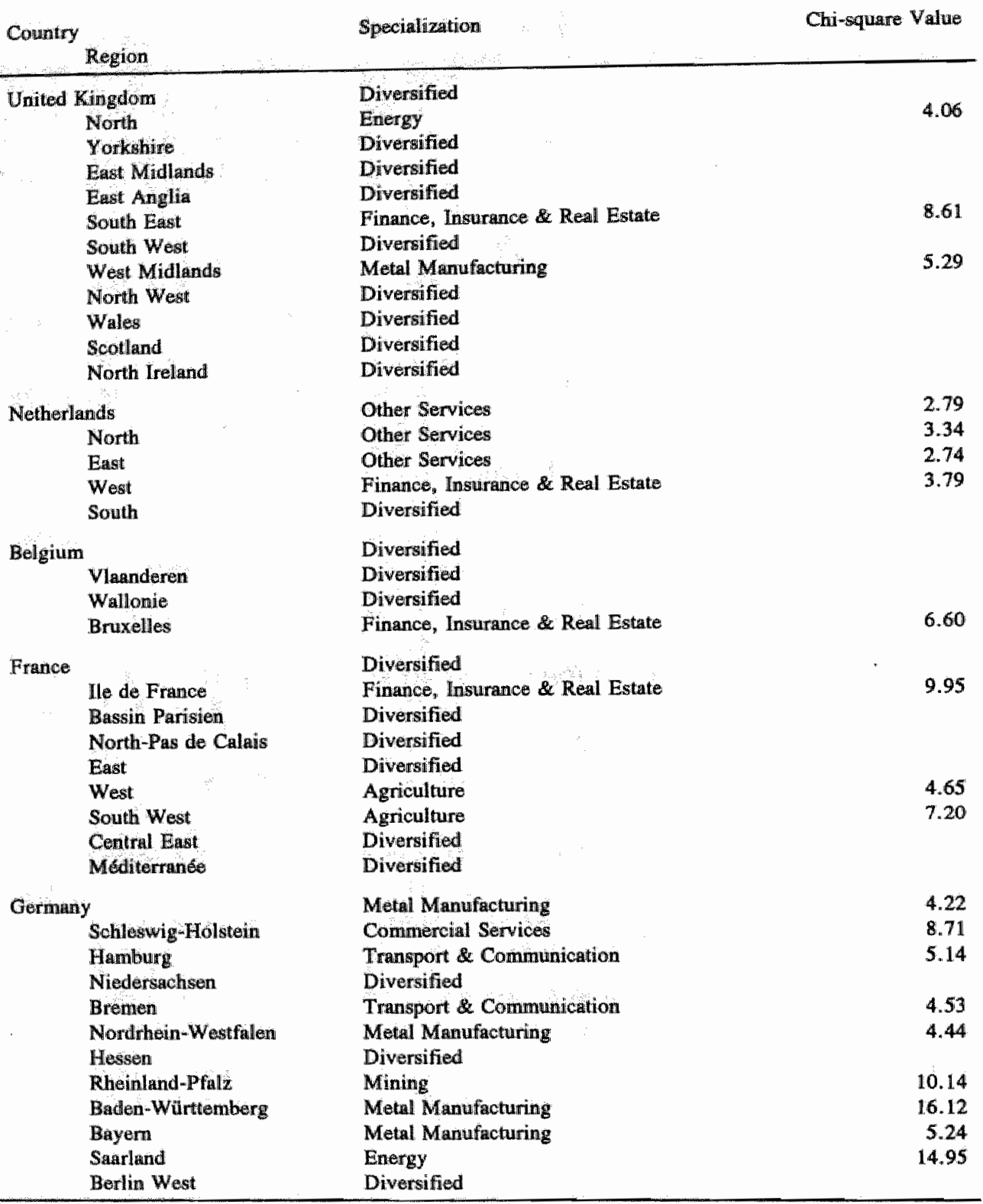

Note: Significance at the $90 \%, 95 \%$, and $99 \%$ levels is at $2.71,3.84$, and 6.64 , respectively. 
Table 2.2: Employment Specialization in European Regions, Results Including Agricultural Employment (Continued).

Country

Specialization

Chï-square Value

Region

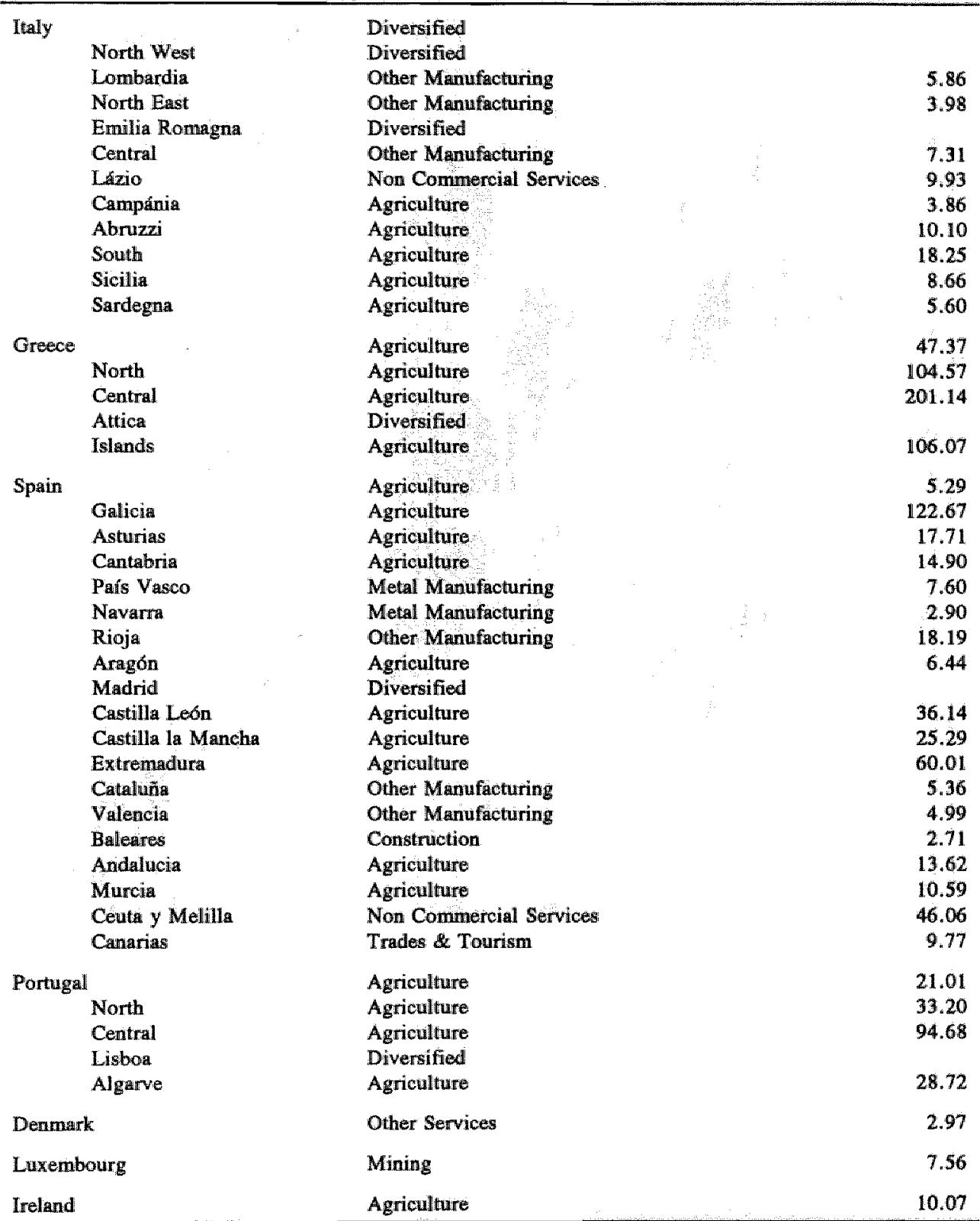


Figure 2.2

Regional Employment Specialization Including Agricultural Employment

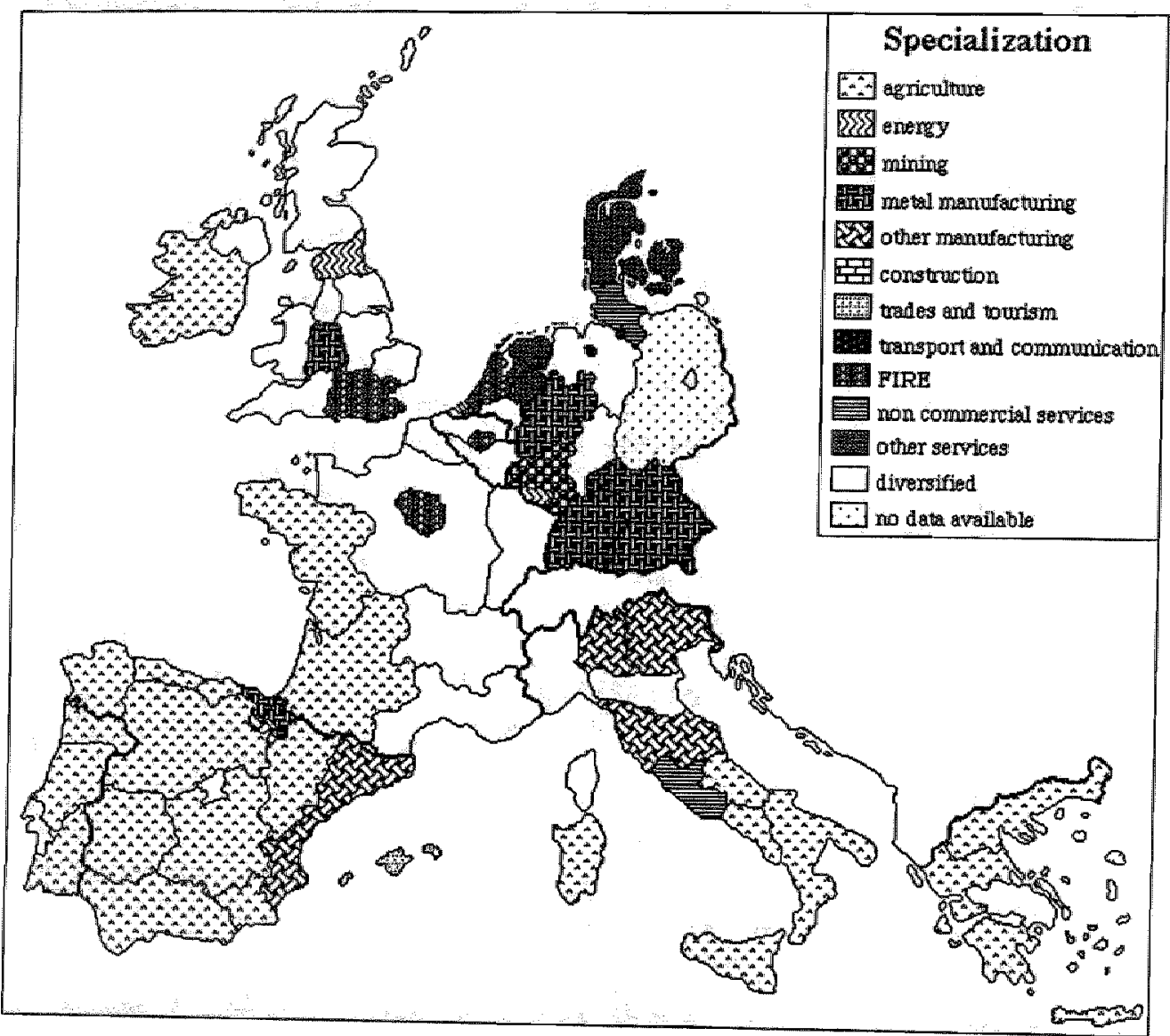


previously classified as diversified become agriculturally oriented (See Table 2.2). Indeed, 22 of the 74 regions have a dominant employment specialization in agriculture, as do four of the 12 countries: Ireland, Greece, Portugal, and Spain. Also, several of the regions and countries change from diversified to specialized in some sector other than agriculture, because the European employment shares change with the inclusion of the agricultural sector. For example, while Luxembourg and Germany remain specialized in the mining and metal manufacturing sectors respectively, when agriculture is included, Denmark and the Netherlands become dominated by 'other services". The United Kingdom, France, Italy and Belgium remain in the diversified category:

The differences resulting from the inclusion of agriculture in the analysis at the regional level are most clearly seen in Figure 2.2. Perhaps most striking is the agricultural dominance in Portugal, Spain, Southern Italy and Greece. This contrasts to the results shown in Table 2.1 and Figure 2.1, with agriculture excluded, when these regions were dominated by several different sectors. A similar phenomenon occurs in Western France, which for the most part was diversified in the non-agriculture results. For all of the regions in the Northern part of Europe, the inclusion of agriculture does not change the picture of employment concentrations.

\subsection{Conclusions}

Real estate investing has traditionally been oriented on specific properties. However, especially in the United States, the focus of analysis is shifting from specific properties to the total real estate portfolio. Europe will no doubt follow the lead. This implies that the diversification of the European real estate portfolio will be a key issue to reall estate investors. In this study, we are concerned with regional diversification.

Determining the optimal regional diversification of the real estate portfolio is difficult. For Europe even more than for the United States, the lack of property returns data on a regional level hampers the use of standard portfolio models. This chapter offers a way to analyze regional diversification of the real estate portfolio without requiring property returns data on a regional level. We develop an instrument with which economic diversification of the real estate portfolio can be accomplished, based on regional employment characteristics. 
We examine economic diversification and specialization in 74 European regions. To analyze the data, we develop and use a modified chi-square technique, which enables classification into diversified or specialized categories. The analysis is performed both with and without considering agricultural employment.

The contribution of this analysis is twofold. First, we offer a way for institutional investors to analyze the extent of the economic diversification of their real estate portfolios. Employment data are available on a highly disaggregated regional level for most countries belonging to the Organization for Economic Cooperation and Development. This enables analysis of diversification for many more countries than only those for which property returns data is available.

The second contribution of this chapter is in the results of the analysis of regional European economies. The findings are generally in accord with expectations regarding employment concentrations in Europe. Regions with a common specialization are scattered over Europe, so regionally diverse investments are not necessarily economically diverse. A large number of regions were found to be internally diverse, although this finding is less strong when agricultural employment is included as a sector. Of the 74 regions, 22 mostly southern European regions are specialized in agriculture. Surprisingly, when agriculture is included, eight of the twelve countries are specialized. Excluding agriculture, only four countries are specialized. We note that concentration in the 'trades and tourism' sector tends to be combined with a strong construction sector. Also, given the importance of the public sector, it is surprising that only three regions are dominated by 'other services'. 
Appendix 2.A: Division of Economic Activities According to Eurostat.

1. Agriculture

Agriculture and hunting

Forestry

Fishing

2. Energy

Extraction and briquetting of solid fuels

Coke ovens

Extraction of petroleum and natural gas

Minerall oil refining

Nuclear fuels industry'

Production and distribution of electricity, gas, steam and hot water

Water supply: collection, purification and distribution of water

3. Mining

Extraction and preparation of metalliferous ores

Production and preliminary processing of metals

Extraction of minerals other than metalliferous and energy-producing minerals; peat extraction

Manufacture of non-metallic mineral products

Chemical industry

Man-made fibres industry

4. Metall Manufacturing

Manufacture of metal articles

Mechanical engineering

Manufacture of office machinery and data processing machinery

Electrical engineering

Manufacture of motor vehicles and of motor vehicle parts and accessories

Manufacture of other means of transport

Instrument engineering

5. Other Manufacturing

Food, drink and tobacco industry

Textile industry

Leather and leather goods industry

Footwear and clothing industry

Timber and wooden furniture industries

Manufacture of paper and paper products; printing and publishing

Processing of rubber and plastics

Other manufacturing industries 


\section{Appendix 2.A: : Division of Economic Activities According to Eurostat (Continued).}

\section{Construction}

Building and civil engineering

7. Trades and Tourism

Wholesale distribution

Dealing in soap and waste materials

Agents

Retail distribution

Hotels and catering

Repair of consumer goods and vehicles

8. Transport and Communication

Railways

Other land transport

Inland water transport

Sea transport and coastal shipping

Air transport

Supporting services to transport

Travel agents, freight brokers and other agents facilitating transport; storag and warehousing

Communication

9. Finance, Insurance and Reall Estate

Banking and finance

Insurance except for compulsory social insurance

Activities auxiliary to banking, finance and real estate transactions; busines services

Renting, leasing and hiring of movables

lotting of real estate by the owner

10. Non Commercial Services

Public administration, national defence and compulsory social security

11. Other serwices

Sanitary services and administration of cemetteries

Education

Research and development

Medical and other health services, veterinary services

Other services provided to the general public

Recreational services and other cultural services

Personal services 
Appendix 2.B1: Regional Disaggregation in Europe, Explamation of the Map.

\begin{tabular}{|c|c|c|}
\hline $\begin{array}{l}\text { Country } \\
\text { Region }\end{array}$ & Abbreviation in Map & City of Importance \\
\hline \multicolumn{3}{|l|}{ United Kingdom } \\
\hline North & no & Newcastle upon Tyne \\
\hline Yorkshire & yo & Leedls \\
\hline East Midlands & $\mathrm{em}$ & Norwich \\
\hline East Anglia & ea & Cambridge \\
\hline South East & se & London \\
\hline South West & sw & Bristol \\
\hline West Midlands & wm & Birmingham \\
\hline North West & $\mathrm{n}$ & Liverpool, Manchester \\
\hline Wales & wa & Cardiff \\
\hline Scottland & $\mathrm{se}$ & Glasgow \\
\hline North Ireland & ni & Belfast \\
\hline \multicolumn{3}{|l|}{ Netherlands } \\
\hline North & $\mathbf{n}$ & Groningen \\
\hline East & e & Enschede \\
\hline West & $w$ & Amsterdam, Rotterdam, The Hague \\
\hline South & $\mathbf{s}$ & Eindhoven \\
\hline
\end{tabular}

Belgium

$\begin{array}{lll}\text { Vlaanderen } & \text { vl } & \text { Antwerp } \\ \text { Bruxelles } & \text { br } & \text { Brussels } \\ \text { Wallonie } & \text { wa } & \text { Liege }\end{array}$

France

Ile de France

if Paris

Bassin Parisien

bp Rouen, Le Mans, Orléans

North-Pas de Calais

np Lille, Roubaix

East

West

South West

8

Strasbourg

Central East

Rennes, Nantes

Méditerranée

Bordeaux, Toulouse

5⿹

co

Lyon

the Marseille, Nice

Germany

Schleswig-Holstein

Hamburg.

Niedersachsen

Bremen

Nordrhein-Westfallen

Hessen

Rheinland-Pfalz

Baden-Württemberg

Bayern

Saarland

Berlin West

Kiel

Hamburg

Hannover

Bremen

Dusseldorf, Köln

Frankfurt

Koblenz

Stultgart

München

Saarbrïcken

West Berlin 
Appendix 2.B1: Regional Disaggregation in Europe, Explanation of the Map (Continued).

\begin{tabular}{|c|c|c|c|}
\hline Country & Region & Abbrewiation in Map & City of Importance \\
\hline \multirow{12}{*}{$\begin{array}{l}1 \\
A \\
S\end{array}$} & & & \\
\hline & North West & $\mathbf{n w}$ & Torino \\
\hline & Lombardia & lo & Milano \\
\hline & North Eiast & ne & Wenézila \\
\hline & Emilia Ronagna & er & Bologma \\
\hline & Central & $\mathrm{c}$ & Firenze \\
\hline & Lazio & 12 & Roma \\
\hline & Campinia & ca & Napoli \\
\hline & Abruzzi & $a b$ & Pescara \\
\hline & South & 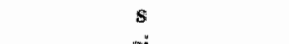 & Bari \\
\hline & Sicilla & si & Palermo \\
\hline & Sardegna & sata & Cagliari \\
\hline \multicolumn{4}{|l|}{ Greece } \\
\hline & North & $\mathbf{n}$ & Thessaloniki \\
\hline & $\begin{array}{l}\text { Central } \\
\text { Attica }\end{array}$ & $\begin{array}{c}c \\
\text { at }\end{array}$ & Athens \\
\hline & $\begin{array}{l}\text { Attica } \\
\text { Islands }\end{array}$ & is & \\
\hline \multicolumn{4}{|l|}{ Spain } \\
\hline & Galicia & $\mathrm{ga}$ & La Coruña \\
\hline & Asturias & as & Gijón \\
\hline & Cantabria & $\mathbf{c b}$ & \\
\hline & Pals Vasco & pv & San Sebastian, Bilbao \\
\hline & Rioja & ri & Burgos \\
\hline & Navarra & na & Pamplona \\
\hline & Aragớn & ar & Zaragoza \\
\hline & Cataluña & ca & Barcelona \\
\hline & Valencia & va & Valencia \\
\hline & Madrid & $\operatorname{ma}$ & Madrid \\
\hline & $\begin{array}{l}\text { Castilla la Mancha } \\
\text { Extremadura }\end{array}$ & $\begin{array}{l}\mathrm{cm} \\
\mathrm{ex}\end{array}$ & \\
\hline & Castilla León & el & Valladolid \\
\hline & Andalucia & an & Sevilla, Malaga, Granada \\
\hline & Murcia & mu & Murcia \\
\hline & Baleares & bat & Palma de Mallorca \\
\hline & Ceuta y Melilla & $\mathrm{cm}$ & \\
\hline & Canianias & $\mathrm{cn}$ & \\
\hline \multicolumn{4}{|c|}{ Portugal } \\
\hline & North & $\mathbf{n}$ & Porto \\
\hline & Central & $c$ & \\
\hline $\mathrm{Li}$ & Lisbon & ii & Lisboa \\
\hline & Algarve & a & Faro \\
\hline \multicolumn{2}{|l|}{ Denmark } & & Kopenhagen \\
\hline \multirow{2}{*}{\multicolumn{2}{|c|}{$\begin{array}{l}\text { Luxembourg } \\
\text { reland }\end{array}$}} & & Luxembrourg \\
\hline & reland & & Dublin \\
\hline
\end{tabular}




\section{Appendix 2.B2 \\ Regional Disaggregation in Europe}

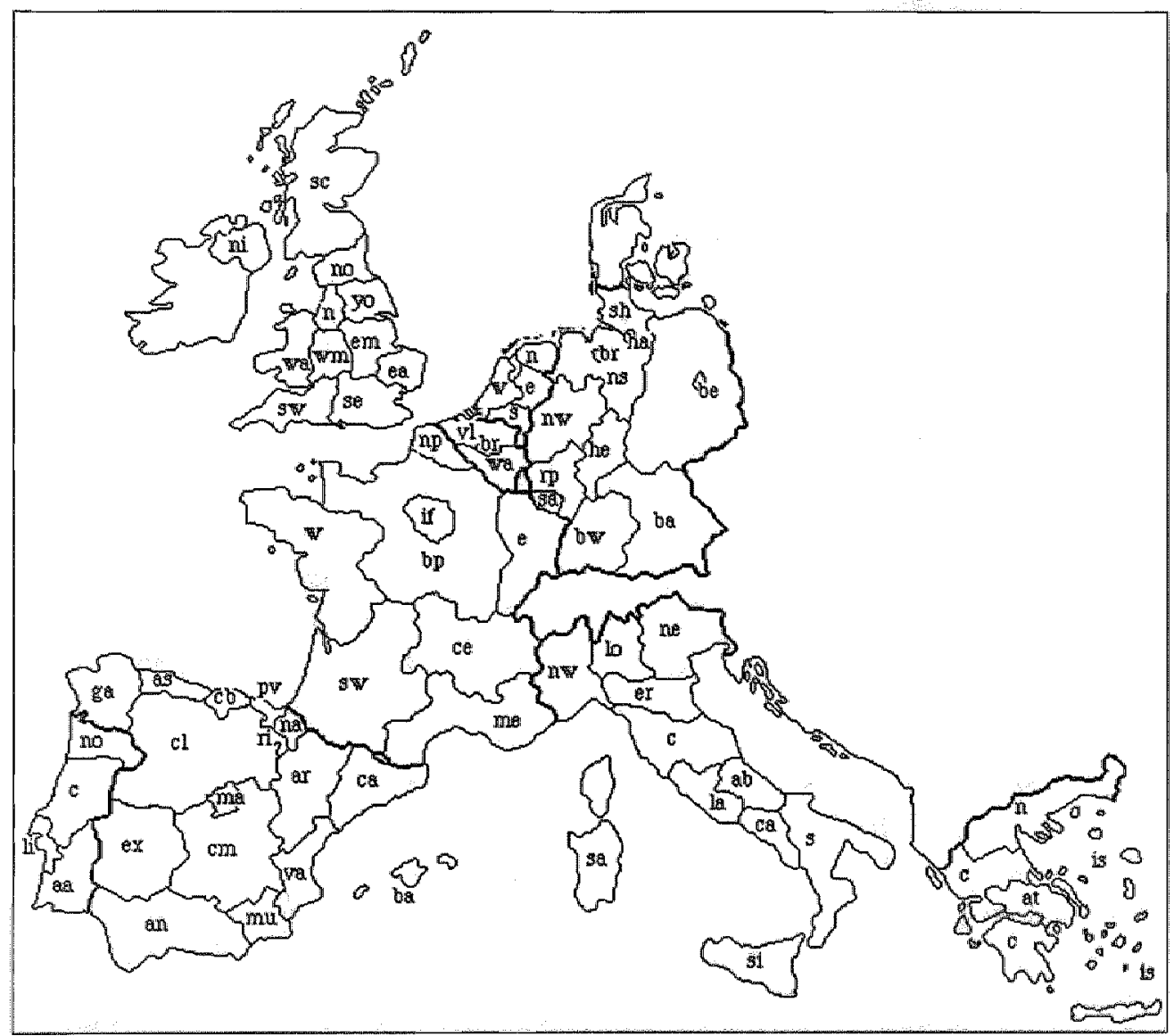




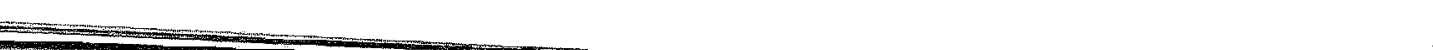




\section{Chapter 3 \\ Regional Economic Stability and Mortgage Default Risk in the Netherlands}

Like many countries, the Netherlands has a program of incentives for private home-ownership. It consists mainly of tax advantages and subsidies, but a public mortgage insurance system is also included in the program. This mortgage insurance system is called Gemeentegarantie (Municipal Guarantee). It was founded in 1976.

The system is run partly by the central government and partly by the municipalities. Families apply for mortgage insurance at the municipality. The municipality sends the application to an organization called Bemiddelend Orgaan (Intermediating Body), which advises the municipality whether to grant the insurance or not. This advice is followed by the municipalities in $97 \%$ of all cases. The criteria on which the advice is based are the same for all municipalities.

Three criteria are essential to the advice. The first is the ratio of annual mortgage payments to gross regular income of the household. Basically, this ratio can not be higher than $20 \%$, but depending on subsidies and tax deductions it can be adjusted upwards. If a family has prior financial obligations, then these will be added to the annual mortgage payments in the calculation of the ratio. Information about existing loans is obtained at the Bureau Kredietregistratie (Bureau of Credit Registration). The second criterion is the ratio of the amount of the mortgage loan and the appraised value of the house. This ratio can be no more than $100 \%$. The appraisal of the house has to be executed by an appraiser who is independent of the transaction at hand. The third criterion is related to the second. It is the amount of the mortgage loan. The maximum is Dfl 250,000 .(Stichting Gezamelijke Bemiddelende Organen, 1992).

A distinguishing feature of the Municipal Guarantee system is that mortgagers pay no insurance premiums for the guarantee. The system is fully subsidized by the government. Losses on a defaulted mortgage are shared equally by the central government and the municipality that granted the mortgage. The losses 
of the system have been quite substantial. Losses were quite low before 1983, but this is mainly due to the fact that the system only just started in 1976 in its current form. In 1985, losses reached a peak of about 90 million Dutch guilders. Since then, they have come down, but a discussion whether to introduce insurance premiums has continued ever since.

Two traits of the system deserve further comment. The first is that municipalities and central government equally share the risk of the mortgage guarantees. An advantage of this system is that the body which grants the insurance also bears part of the risk. This prevents agency problems and gives the municipality an incentive to assess the risk of the applications properly.

On the other hand, the municipality runs more risk than the centrall government, for the same zero premium income. This is easily seen if we look at the problem from a portfolio point of view. The central government has diversified part of the risk of the mortgage portfolio, since it has the whole population of insured mortgages in portfolio. In other words, it holds the market portfolio, and consequently only runs market risk. The municipality, on the other hand, only has a small subset of the market in portfolio. Thus, it runs the market risk plus the unique risk the government has diversified away. For this extra risk, the municipality is not rewarded, which is logical, since it can be diversified away in principle. Clearly, this is not economically efficient. The problem could be solved by an insurance system in which all risk is borne by the central government, or by another central body that insures the whole market. In most countries with a mortgage guarantee system, a centralized system already exists.

The second trait of the Dutch system that deserves further comment is that, since all premiums are zero, no premium differentiation exists with respect to municipalities. If mortgage portfolios in some municipalities are more risky than those in others, then it would be economically efficient to take these differences into account in the premiums. In the current system, mortgagers in risky regions receive higher subsidies than other mortgagers.

A key question is thus whether regional differences in the riskiness of mortgage portfolios exist. In this chapter, we show that regional differences in the riskiness of mortgage portfolios indeed exist. Furthermore, we demonstrate that these differences can be explained by the degree of economic diversification in the regions and by the degree of economic stability. This implies that the degree 
of regional economic stability and diversification should be taken into account when introducing premiums in the system.

This chapter is organized as follows. In Section 3.1, we review the relevant literature and discuss the methodology. In Section 3.2, the data we use is outlined. Section 3.3 gives results about the relationship between economic diversification and mortgage portfolio risk, and Section 3.4 concludes the chapter.

\subsection{Measures of Economic Diversity and Stability}

The link between regional economic characteristics and the risk of real estate portfolios has had some attention in the literature. Shulman and Hopkins (1988) intuitively link local economic diversity to real estate risk. They use regional employment characteristics to construct measures of local economic diversity and link these measures to commercial property, without formally testing this link. Shulman and Hopkins do not use any formal measure for local economic diversification. This approach is similar to the one we use in Chapter 2. The difference is that we actually measure local economic diversification. Corgel and Gay (1987) also use regional economic diversification and stablity to explain real estate risk. They concentrate on residential mortgage portfolio risk. Without formally testing it, Corgel and Gay argue that geographic diversification can decrease mortgage default and prepayment risk.

Clauretie (1988) links local economic diversity and stability to mortgage default risk, and he formally tests the idea. To determine the degree of economic diversity in a region, he uses measures from the regional economics literature, based on regional employment characteristics. He investigates whether the degree of diversity can explain residential mortgage default rates, and compares different measures in their ability to explain these mortgage default rates. He finds that dynamic measures give a better explanation for mortgage default risk than static measures.

In this chapter, we follow the footsteps of Clauretie and analyze the relationship between indicators of local economic diversity and stability and mortgage default risk. More specifically, we test two separate hypothesis. One is that mortgage default risk is relatively low in economically diverse regions, and the 
other is that mortgage default risk is relatively low in economically stable regions. We test these hypotheses separately by first cross-sectionally regressing the annual mortgage default rate in a region on measures of regional economic diversification and then on measures of regional economic stability. Our general model is of the form

$$
D_{r}=\alpha+\beta M_{r}+\epsilon
$$

where $\alpha$ is a constant and $\beta$ reflects the relationship between $D_{r}$, the logarithm of the default rate in region $r$, and $M_{r}$, which is either some measure of economic diversification or of economic stability in region $r$.

We estimate (3.1) in annual Ordinary Least Squares (OLS) regressions, from 1983 through 1990. However, we expect the relationship between the stability measures and the mortgage rate to be fundamentally stable over time. Therefore, we want to pool the individual OLS regressions. For this, the method we use here is Seemingly Unrelated Regression with restricted $\beta$ 's, since it requires no additional assumptions regarding the error structure of the annual regression equations (See Judge et al., 1982, and Zellner, 1962). In this setup, $\beta$ is fixed over time, while $\alpha$ is allowed to vary.

Since the model is cross sectional, we implicitly assume that no institutional differences in the mortgage guarantee system exist between regions. In the introduction we described the criteria on which the judgement of mortgage applications is based. No differences in these criteria exist between municipalities. However, we did not describe foreclosure procedures. Clauretie (1987, 1988) shows that these can have a significant influence on mortgage default rates.

Formally, all municipalities foreclosure procedures are based on equal rules in the Netherlands. In practice, differences exist. In our model, we should therefore include independent variables which take the differences in these procedures into account. However, these differences are all informal and quantitative information about these procedures is therefore impossible to obtain. This could in principle have an impact on our results, but we believe his problem to be of limited importance. We execute our analysis at two levels of regional disaggregation. One distinguishes 30 regions, the other 12 . There were 887 municipalities in the Netherlands in 1990 . Since each region consists 
of a number of municipalities, the differences in foreclosure procedures are diversified if we go from a municipal level of observation to a regional level. The more we aggregate, the more we limit the influence of this problem. The use of two levels of regional disaggregation allows us to investigate the magnitude of the problem. If we find conflicting results between the two levels of disaggregation, than the lack of information regarding foreclosure procedures plays an important role, and inferences based on those results can not be made. However, if we find simillar results for the two levels of disaggregation, the problem does not play a significant role. Probably, our results will be somewhere in between. Therefore, we expect the results on the 12-region level to be somewhat stronger than those on the 30-region level.

In our model, the independent variable is some measure of regional economic diversity and stability. To develop such measures, we explore two branches of literature. The first is the regional economics literature, in which many measures have been developed to describe regional diversity and stability. In some cases, these measures were linked to real estate performance. The second branch of literature is the industrial economics literature. Here, measures have been developed to describe diversity and stability of markets. These issues are very much like regional economic stability, and the measures developed in this field can be used to construct better measures for regional economic stability.

In the regional economics literature, the first relevant work for this study was by Florence (1948) and Steigenga (1955). They proposed a static diversity measure in which the sector proportions of employment in a region are compared to the national average sector proportions. Thus, this National Average measure defines a diversified region as one in which the proportion of employment in each sector is equal to the national economy. In such a case, the measure equals zero. Our hypothesis is that a diversified region has a low mortgage default rate. We therefore expect a positive relationship between the National Average measure and the mortgage default rate. For region $r$, the measure is

$$
N A=\sum_{i=1}^{n} \frac{\left(S_{i r}-S_{i e}\right)^{2}}{S_{i e}}
$$

where $S_{i r}$ is the employment share of sector $i$ in region $r$, and $S_{l e}$ is the national 
employment share of sector $i$. There are $n$ sectors.

Conroy (1975) uses a Markowitz framework to construct his dynamic measure of regional economic diversification. He considers each region as a portfolio of industries, or economic sectors. For each region, he calculates a portfolio variance in employment terms. First, he calculates a national covariance matrix of employment, by correlating time series of national sector employment. Then, he calculates the portfolio variance for each region by using this national covariance matrix and the sector employment shares in each region. If this portfolio variance is zero, the economy of this region is perfectly stable. Thus, this Conroy Portfolio measure defines a stable regional economy as one in which fluctuations of regional employment around a given regional employment level are minimized. In other words, an economy with zero growth is defined as stable. The measure does not take population growth into account. This implies that if the population is growing, the measure defines an economy with decreasing per capita income as stable.

We adjust the Conroy Portfolio measure so that it defines a perfectly stable economy as one in which shifts in sector shares do not occur. We calculate a national covariance matrix based on the correlation matrix of the time series of sector shares in the national economy and the variance in these time series. Then, we calculate a portfolio variance for each region by using this national covariance matrix and the sector employment shares in each region. We expect a positive relationship between our adjusted Conroy Portfolio measure and the mortgage default rate. Our Conroy Portfolio measure for region $r$ is

$$
C P=\sum_{i=1 j=1}^{n} \sum_{i j}^{n} S_{j r} \sigma_{i j}
$$

where $S_{i r}$ is the employment share of sector $i$ in region $r, S_{j r}$ is the employment share of sector $j$ in region $r$, and $\sigma_{i j}$ is the national covariance of employment shares between sector $i$ and sector $j$.

We can find problems very similar to regional economic stability and diversity in the industrial economics literature. Many measures have been developed to describe optimally the diversity and stability of markets. These measures, either static or dynamic, are all based on market shares of companies operating in a particular market. It is but a small step to go from market shares to employment 
shares and from diversity and stability of markets to diversity and stability of local economies. Therefore, it can be very illuminating to compare the measures from the regional science literature to some measures which have been proposed to describe stability of markets. Baldwin and Gorecki (1989) and Buijink and Maijoor (1992) give an overview of these measures and also compare their information outcomes when it comes to describing markets.

If we use static measures to explain mortgage default rates, like a National Average measure, we test a joint hypothesis. Specifically, we jointly test the hypotheses that concentrated economies are unstable, and that mortgage portfolios in unstable economies are relatively risky. On the other hand, if we use dynamic measures, we directly measure economic stability. In that case, we no longer test a double hypothesis, but a single one: unstable economies lead to high mortgage default risk. Theoretically, therefore, using dynamic measures is more sound than using static measures. Clauretie (1988) tests both dynamic and static measures and finds that static measures are outperformed in explaining mortgage default rates. More specifically, he finds the Conroy Portfolio measure to give the most significant explanation of mortgage risk.

Nevertheless, we test both static and dynamic measures as explanatory variables to mortgage default rates. We use two static and four dynamic measures. The first static measure is the National Average measure in (3.2). The other static measure is the Herfindahl index, which is the sum of the squared sector employment shares in a regional economy. It implicitly defines an optimally diversified economy as one in which there are many sectors, which all have an equal share of total employment in the economy. It has the problem that its absolute level is very dependent of the way the national bureau of statistics defines economic sectors. However, since we compare regions in which economic sectors have all been defined in the same way, this problem is not relevant here. The Herfindahl index is

$$
H=\sum_{i=1}^{n}\left(S_{i r}\right)^{2}
$$

This measure can vary between zero and one. If it is zero, the economy is fully diversified; if it is one, the economy is perfectly specialized. Thus, we expect a positive relationship between the Herfindahl index and the mortgage default 
rate.

The first dynamic measure we use is the Conroy Portfolio measure (3.3). As a second dynamic measure, we take the sum of the absolute value of the share changes of all sectors in a region divided by two. This measure was first proposed by Hymer and Pashigian (1962). For region $r$, the measure is

$$
H P=\frac{\sum_{i=1}^{n}\left|S_{i n(t)}-S_{i r(t-1)}\right|}{2}
$$

where $S_{i r(t)}$ is the employment share of sector $i$ in region $r$ in year $t$. This measure provides a metric in which the amount or severity of change in a local economy can be evaluated. It varies from zero to one, where zero means stability and one means instability. We expect a positive relationship between the Hymer-Pashigian measure and mortgage default rates.

The third dynamic measure is due to Cable. It is the sum of the squared sector share changes. It is analogous to the Hymer-Pashigian measure but it gives more weight to large absolute sector share changes and is therefore less influenced by possible small sample effects in the employment data. It is:

$$
C=\sum_{i=1}^{n}\left(S_{i r(t)}-S_{i r(t-1)}\right)^{2}
$$

The fourth and last dynamic stability measure is a correlation measure. For each region, it calculates the correlations of the vector of sector shares in a year with the vector of sector shares in the previous year. This measure defines a stable economy as an economy in which the sector shares do not change. In that case, the Correllation measure equals one. Therefore, we expect a negative relationship between the Correlation measure and the mortgage default rate. The measure is: 


$$
C O=\operatorname{cor}\left(S_{n}, S_{n-1}\right)
$$

where $S_{r t}$ is the vector of sector employment shares in region $r$ in year $t$. We now have two static and four dynamic measures. All six measures are solely based on the employment characteristics of a region.

\subsection{Employment and Mortgage Default Data}

To develop our diversity and stability measures we use employment data. The Central Bureau of Statistics annually produces the Statistiek Werkzame Personen (Statistics of Employed People), based on a sample survey of households. The results are published on three levels of sector disaggregation, and on two levels of regional disaggregation. We use the second level of sectoral disaggregation, which distinguishes 8 sectors: Agriculture, Mining/Manufacturing, Utility, Construction, Trades/Tourism, Transport/Communication, Finance/Insurance/Real Estate, and Other Services. Detailed information about the sectoral decomposition is included in Appendix 3.A.

With regards to the regional disaggregation, the Central Bureau of Statistics uses the provincial level, where twelve provinces are distinguished, and the COROP level, where 43 socalled COROP regions are distinguished. However, for the less densely populated COROP regions, due to the small sample effect, the data is not very reliable. Therefore, to increase the reliability, we put some of the small regions together, going from 43 to 30 regions in the process. We also perform our analysis using the first, provincial level. We did this to limit the small sample effect further, and to test the robustness of our results with respect to the small sample effect. Appendix 3.B includes a map of the Netherlands which distinguishes both the 30 regions and the 12 provinces. An accompanying list of names of regions and provinces is also included.

Based on this employment data, we calculate our six measures. For all but the Conroy Portfolio measure, we do this for 1983 through 1990. To calculate the national covariance matrix in the Conroy Portfolio measure, we need employment time series with some history. We only have employment data from 1969, which means we have to make a trade-off between the reliability of the covari- 
ance matrix and the number of years for which we can calculate the Conroy Portfolio measure. We use twenty annual observations to calculate the matrix. Using more observations would allow us to calculate the measure for two years at most. Using less observations for the matrix calculations would limit the significance of the matrix. Our choice of twenty observations for the matrix implies we can only calculate the Conroy Portfolio measure for 1988, 1989, and 1990.

As we noted before, we use the indicators of regional economic diversity and stability to explain mortgage default rates in the Netherlands. The mortgage default data we use is from a database of defaulted publicly insured mortgages in the Netherlands. This dataset provides the possibility of research on mortgage default risk in the Netherlands, which has been hitherto impossible due to lack of data. The dataset contains the whole population of defaulted guaranteed mortgages from 1983 through 1990 . In these eight years, a total of 8558 mortgages defaulted. The beginning of the time period was characterized by financial instability and a crisis in the housing market. This caused negative equity for many home-owners and mortgage default rates soared. The end of the time period was more stable. Figure 3.1 contains an overview of numbers of mortgage defaults for 1983 through 1990 . We group the defaults by year and by region. We use the two levels of regional disaggregation mentioned above.

The fact that we only look at insured mortgages could influence our results. For example, insured mortgages could default more frequently than uninsured mortgages. However, we do not look at the absolute riskiness of the mortgages. We only look at mortgage default risk in some individual region relative to other regions.

Of course, the number of mortgage defaults in a region is by itself useless, we have to look at it as a percentage of total insured mortgages outstanding in that region. Unfortunately, the total number of insured mortgages is not available on a regional basis. Therefore, we take the number of total mortgages outstanding per region as a stand-in. We obtained the information about total mortgages outstanding per region from the Central Bureau of Statistics (1983-1990). A problem with using all mortgages outstanding as a stand-in is that the level of our mortgage default rate is not interpretable. 
Figure 3.1

Guaranteed Mortgage Defaults in the Netherlands

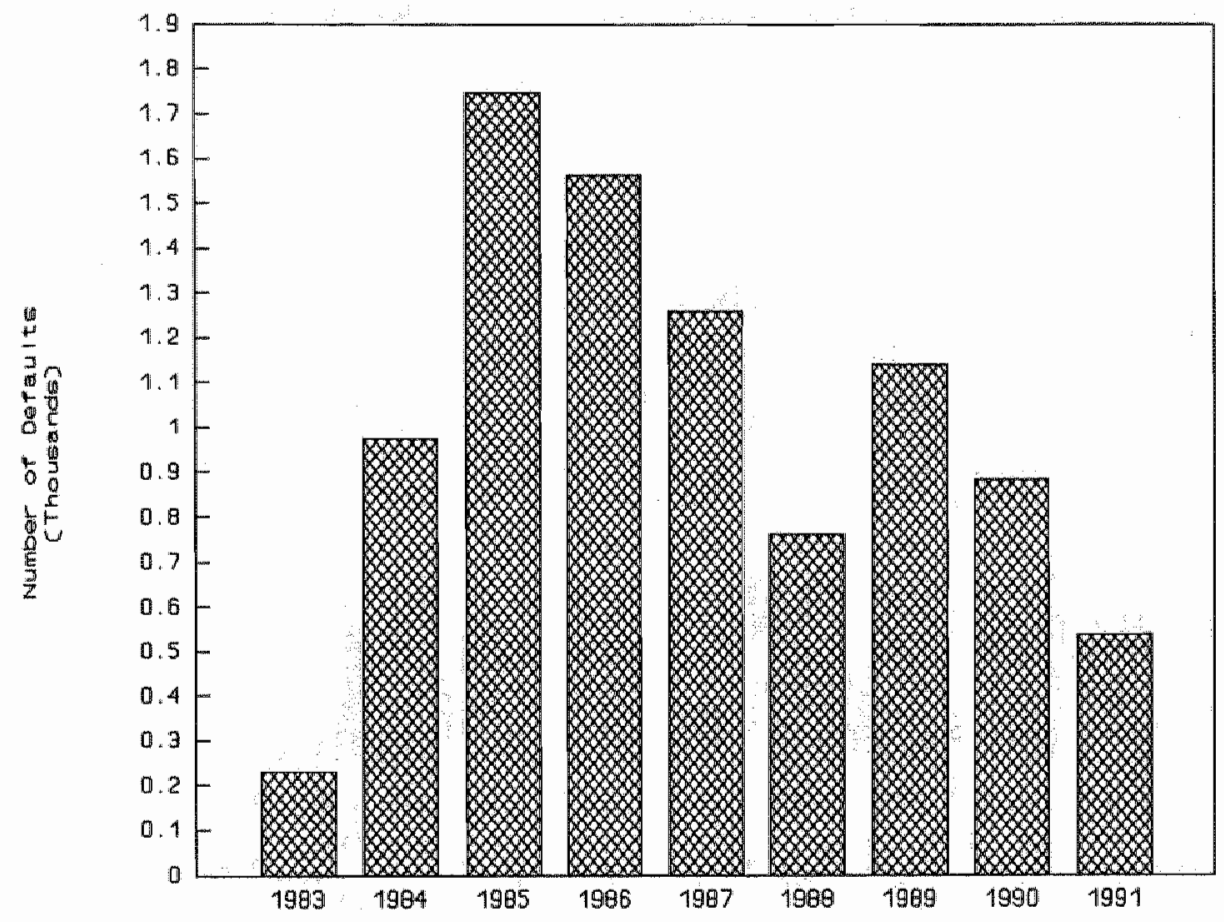




\subsection{Do Economic Stability and Diversity Influence Mortgage Default Risk?}

We test our regression model annually from 1983 until 1990 using the two static and four dynamic stability measures we developed in Section 3.2. For two levels of regional disaggregation, we use both OLS regressions and Seemingly Unrelated Regressions to test the model.

We first test the model on the second level of regional disaggregation: the 30 regions. The OLS regression results for each measure are in Table 3.1. The first two panels of this table give information about the static measures: the National Average measure and the Herfindahl index. For both measures, we either find no significant relationship with mortgage default rates, or we find a significant relationship which does not have the expected sign. In the last four panels of Table 3.1 , we included the results for the dynamic measures: the Conroy Portfolio measure, the Hymer-Pashigian measure, the Cable measure, and the Correlation measure. These measures yield more promising results. Especially the Cable and Correlation measures perform well. Both are significant in most years and have the expected sign. However, adjusted $\mathbf{R}^{2} \mathrm{~s}$ are always low.

The next table, Table 3.2, shows the results if we pool the annual regressions in a Seemingly Unrelated Regression setup. This makes the $\mathbb{R}^{2} \mathrm{~s}$ of the regressions uninterpretable, so we only report the standard error of the equations. Again, we use the second level of regional disaggregation. Since we expect the relationship between the stability measures and the mortgage default rate to be fundamentally stable over time, we estimate the model, while forcing the $\beta \mathrm{s}$ to be equal in all 8 regression equations. Again, we find the dynamic measures to have considerably more explanatory power than the static measures. The regression coefficients of the static measures both have the wrong sign. Of the dynamic measures, the Hymer-Pashigian measure's results are mixed. The sign is as intuitively expected, but the t-value of the regression coefficient is only 0.646. The Conroy Portfolio measure, on the other hand, shows a significant rellationship to mortgage default risk, but it does not have the expected sign. It is negative in spite of the expected positive relationship. The Cable measure and the Correlation measure's results are most significant. We find significant relationships between these measures and mortgage default rates. Both measures" regression $\beta$ 's have the expected sign. 
The following step in our analysis is to test our regression model using the first, provincial level of regional disaggregation. Table 3.3 contains the results of the OLS regressions on this level. Of the two static measures, the Herfindahl still yields perverse results, but the National Average measure now performs according to expectations. We find very significant regression coefficients. Also, the adjusted $\mathbf{R}^{2} \mathbf{s}$ are high. The dynamic measure's results are mixed. For the Hymer-Pashigian and the Cable measure, the results are similar, although they are somewhat stronger for the Cable measure. The model is well specified for most years and the observed relationships have the expected sign. For the Cable measure, we find high adjusted $R^{2} s$ and a significance level of beta that is $99.5 \%$ for five out of the eight years under observation. For the Correlation measure the model seems generally well specified, but adjusted $R^{2} s$ and significance levels of $\beta$ 's are not very high. The Conroy Portfolio measure's $t$-values and adjusted $\mathbf{R}^{2} \mathrm{~s}$ are low, indicating its weak relationship with mortgage default rates.

In the last part of our analysis, we estimate model (3.1) on the provincial level, again using Seemingly Unrelated Regression. The results are in Table 3.4. Except for the Herfindahl index and the Conroy Portfolio measure, all measures perform well in explaining mortgage default risk. The significance level of the National Average, the Hymer Pashigian, and the Cable measure is $99.5 \%$ in our model. The Correlation measure is significant at the $95 \%$ level.

To conclude the results, our notion that dynamic measures have a more direct link with mortgage defaults than static ones is confirmed. Dynamic measures generally outperform static measures in explaining mortgage default rates. Also, our results on the 30-region level of geographic disaggregation are confirmed by those on the provincial level. The relationships we find tend to be somewhat stronger on the provincial level. This confirms our expectations. We expected the small sample effect to be less disturbing on the provincial level, and the effect of municipal differences in the foreclosure procedures to diminish. We also find that the Cable measure has a stronger explanatory power of mortgage default rates than the Hymer-Pashigian measure. This can probably be attributed to the fact that the latter is less influenced by the small sample effect. Our last main finding is that restricting the regression betas improves our results. This implies that the relationships we investigate are fundamentally stable in time. There are two exceptions to all this. The first is the results for 1989. We find regression results for that year to be inconsistent with other years and expec- 
Table 3.1: Ordinary Least Squares Regressions, 30 Regions.

$$
D_{r}=\alpha+\beta M_{r}+\epsilon
$$

a: $M_{r}=$ National A verage Measure

\begin{tabular}{lcccccccr}
\hline & 1983 & 1984 & 1985 & 1986 & 1987 & 1988 & 1989 & 199 \\
\hline$\alpha$ & -5.46 & -3.84 & -3.52 & -3.40 & -3.74 & -4.39 & -4.00 & -4.2 \\
& $(-37.02)$ & $(-26.17)$ & $(-26.96)$ & $(-21.96)$ & $(-34.61)$ & $(-36.02)$ & $(-28.85)$ & $(-23.3$ \\
$\beta$ & -0.01 & -0.03 & 0.00 & -0.04 & -0.01 & 0.00 & -0.01 & -0.0 \\
& $(-1.21)$ & $(-3.21)$ & $(0.06)$ & $(-2.91)$ & $(-1.03)$ & $(0.29)$ & $(-1.05)$ & $(-2.1$ \\
\multirow{2}{*}{ SEE } & 0.65 & 0.65 & 0.55 & 0.64 & 0.47 & 0.55 & 0.63 & 0.8 \\
$\mathbf{R}_{\text {adj }}{ }^{2}$ & 0.02 & 0.24 & -0.04 & 0.21 & 0.00 & 0.03 & 0.00 & 0.1 \\
\hline
\end{tabular}

b: $M_{r}=$ Herfindahl Index

\begin{tabular}{lcccccccc}
\hline & 1983 & 1984 & 1985 & 1986 & 1987 & 1988 & 1989 & 1991 \\
\hline$\alpha$ & -4.84 & -3.27 & -1.19 & -2.34 & -3.31 & -2.38 & -2.62 & -3.9 \\
& $(-3.73)$ & $(-1.94)$ & $(-1.07)$ & $(-1.51)$ & $(-3.22)$ & $(-2.17)$ & $(-1.96)$ & $\left(-2.0^{\prime}\right.$ \\
$\beta$ & -3.25 & -3.80 & -10.63 & -5.98 & -2.24 & -9.04 & -6.66 & -2.61 \\
& $(-0.56)$ & $(-0.50)$ & $(-2.11)$ & $(-0.88)$ & $(-0.49)$ & $(-1.82)$ & $(-1.10)$ & $(-0.3$ \\
SEE & 0.66 & 0.75 & 0.51 & 0.72 & 0.47 & 0.52 & 0.62 & 0.8 \\
$R_{\text {adj }}{ }^{2}$ & -0.02 & -0.03 & 0.11 & -0.01 & -0.03 & 0.07 & 0.01 & -0.0 \\
\hline
\end{tabular}

c: $M_{r}=$ Conroy Portfolio Measure

\begin{tabular}{|c|c|c|c|c|c|c|c|c|}
\hline & 1983 & 1984 & 1985 & 1986 & 1987 & 1988 & 1989 & 1990 \\
\hline$\alpha$ & & & & & & $\begin{array}{c}-4.21 \\
(-28.10)\end{array}$ & $\begin{array}{r}-3.87 \\
(-22.47)\end{array}$ & $\begin{array}{r}-4.38 \\
(-17.87\end{array}$ \\
\hline$\beta$ & & & & & & $\begin{array}{c}-0.20 \\
(-1.49)\end{array}$ & $\begin{array}{c}-0.28 \\
(-1.58)\end{array}$ & $\begin{array}{r}-0.18 \\
(-0.62\end{array}$ \\
\hline SEE & & & & & & 0.46 & 0.53 & 0.61 \\
\hline $\mathbf{R}_{\mathrm{adi}}{ }^{2}$ & & & & & & 0.04 & 0.05 & -0.02 \\
\hline
\end{tabular}

Note: t-values are denoted in parentheses. 
Table 3.1: Ordinary Least Squares Regressions, 30 Regions (Continued)。

$$
D_{r}=\alpha+\beta M_{r}+\epsilon
$$

d: $M_{r}=$ Hymer Pashigian Measure

\begin{tabular}{lcccccccc}
\hline & 1983 & 1984 & 1985 & 1986 & 1987 & 1988 & 1989 & 1990 \\
\hline$\alpha$ & -5.35 & -4.30 & -3.82 & -4.11 & -4.15 & -4.53 & -3.67 & -4.79 \\
& $(-17.23)$ & $(-9.95)$ & $(-16.34)$ & $(-11.63)$ & $(-25.55)$ & $(-13.53)$ & $(-10.56)$ & $(-11.91)$ \\
$\beta$ & -12.76 & 5.20 & 13.15 & 21.15 & 15.38 & 9.50 & -33.92 & 27.55 \\
& $(0.75)$ & $(0.45)$ & $(1.42)$ & $(1.25)$ & $(2.42)$ & $(0.49)$ & $(-1.25)$ & $(0.81)$ \\
SEE & 0.66 & 0.75 & 0.51 & 0.72 & 0.47 & 0.52 & 0.62 & 0.88 \\
$\mathrm{R}_{\text {adj }}{ }^{2}$ & -0.02 & -0.03 & 0.03 & 0.02 & 0.14 & -0.03 & 0.02 & -0.01 \\
\hline
\end{tabular}

e: $M r=$ Cable Measure

\begin{tabular}{lcccccccc}
\hline & 1983 & 1984 & 1985 & 1986 & 1987 & 1988 & 1989 & 1990 \\
\hline$\alpha$ & -5.85 & -4.46 & -3.83 & -3.90 & -4.06 & -4.59 & -4.16 & -4.70 \\
& $(-26.67)$ & $(-17.77)$ & $(-28.40)$ & $(-19.81)$ & $(-36.63)$ & $(-21.56)$ & $(-21.04)$ & $(-21.11)$ \\
$\beta$ & 66.73 & 87.06 & 130.35 & 111.72 & 220.73 & 388.88 & 291.56 & 1652.36 \\
& $(1.52)$ & $(1.61)$ & $(3.00)$ & $(1.36)$ & $(3.11)$ & $(1.14)$ & $(0.52)$ & $(1.32)$ \\
\multirow{2}{*}{$S E E$} & 0.66 & 0.75 & 0.52 & 0.70 & 0.41 & 0.55 & 0.63 & 0.85 \\
$\mathrm{R}_{\text {adj }}{ }^{2}$ & 0.04 & 0.05 & 0.22 & 0.03 & 0.23 & 0.01 & -0.03 & 0.03 \\
\hline
\end{tabular}

f: $M_{r}=$ Correllation Measure

\begin{tabular}{lcccccccc}
\hline & 1983 & 1984 & 1985 & 1986 & 1987 & 1988 & 1989 & 1990 \\
\hline$\alpha$ & 12.63 & 17.68 & 86.18 & 67.18 & 37.57 & 76.85 & -128.03 & 177.47 \\
& $(0.18)$ & $(0.71)$ & $(3.07)$ & $(1.75)$ & $(3.10)$ & $(0.53)$ & $(-0.83)$ & $(0.99)$ \\
$\beta$ & -18.22 & -21.96 & -89.94 & -71.05 & -41.50 & -81.31 & 124.06 & -182.09 \\
& $(-0.25)$ & $(-0.88)$ & $(-3.19)$ & $(-1.84)$ & $(-3.41)$ & $(-0.56)$ & $(0.81)$ & $(-1.02)$ \\
SEE & 0.66 & 0.75 & 0.47 & 0.69 & 0.40 & 0.54 & 0.63 & 0.86 \\
$\mathrm{R}_{\text {adj }}{ }^{2}$ & -0.04 & -0.01 & 0.24 & 0.08 & 0.27 & -0.02 & -0.01 & 0.00 \\
\hline
\end{tabular}

Note: $t$-values are denoted in parentheses. 
Table 3.2: Seemingly Unrelated Regressions, 30 Regions.

$$
D_{r}=\alpha+\beta M_{r}+\epsilon
$$

a: $M_{r}=$ National Average Measure

\begin{tabular}{lcccccccc}
\hline & 1983 & 1984 & 1985 & 1986 & 1987 & 1988 & 1989 & 1990 \\
\hline$\alpha$ & -5.52 & -4.08 & -3.48 & -3.66 & -3.76 & -4.33 & -4.03 & -4.44 \\
& $(-43.57)$ & $(-31.31)$ & $(-31.29)$ & $(-28.67)$ & $(-39.20)$ & $(-37.67)$ & $(-33.21)$ & $(-28.86)$ \\
$\beta$ & -0.01 & -0.01 & -0.01 & -0.01 & -0.01 & -0.01 & -0.01 & -0.01 \\
& $(-0.91)$ & $(-0.91)$ & $(-0.91)$ & $(-0.91)$ & $(-0.91)$ & $(-0.91)$ & $(-0.91)$ & $(-0.91)$ \\
SEE & 0.65 & 0.73 & 0.55 & 0.71 & 0.47 & 0.56 & 0.63 & 0.86 \\
$\mathbf{R}_{\text {adj }}{ }^{2}$ & & & & & & & & \\
\hline
\end{tabular}

b: $M_{r}=$ Ferfindahl Index

\begin{tabular}{lcccccccc}
\hline & 1983 & 1984 & 1985 & 1986 & 1987 & 1988 & 1989 & 1990 \\
\hline$\alpha$ & -4.24 & -2.80 & -2.22 & -2.34 & -2.48 & -3.06 & -2.77 & -3.19 \\
& $(-6.48)$ & $(-4.30)$ & $(-3.47)$ & $(-3.51)$ & $(-3.81)$ & $(-4.78)$ & $(-4.33)$ & $(-4.92)$ \\
$\beta$ & -5.95 & -5.95 & -5.95 & -5.95 & -5.95 & -5.95 & -5.95 & -5.95 \\
& $(-2.07)$ & $(-2.07)$ & $(-2.07)$ & $(-2.07)$ & $(-2.07)$ & $(-2.07)$ & $(-2.07)$ & $(-2.07)$ \\
\multirow{2}{*}{$\mathrm{SEE}^{2}$} & 0.66 & 0.76 & 0.52 & 0.72 & 0.48 & 0.52 & 0.62 & 0.88 \\
$\mathrm{R}_{\text {adj }}{ }^{2}$ & & & & & & & & \\
\hline
\end{tabular}

c: $M_{r}$ Conroy Portfolio Measure

\begin{tabular}{|c|c|c|c|c|c|c|c|c|}
\hline & 1983 & 1984 & 1985 & 1986 & 1987 & 1988 & 1989 & 1990 \\
\hline$\alpha$ & & & & & & $\begin{array}{c}-4.18 \\
(-30.48)\end{array}$ & $\begin{array}{c}-3.90 \\
(-27.72)\end{array}$ & $\begin{array}{c}-4.33 \\
(-25.04)\end{array}$ \\
\hline$\beta$ & & & & & & $\begin{array}{c}-0.24 \\
(-1.99)\end{array}$ & $\begin{array}{c}-0.24 \\
(-1.99)\end{array}$ & $\begin{array}{c}-0.24 \\
(-1.99)\end{array}$ \\
\hline SEE & & & & & & 0.41 & 0.54 & 0.59 \\
\hline $\mathrm{R}_{\mathrm{adj}}{ }^{2}$ & & & & & & & & \\
\hline
\end{tabular}

Note: t-values are denoted in parentheses. 
Table 3.2: Seemingly Unrelated Regressions, 30 Regions (Continued).

$$
D_{r}=\alpha+\beta M_{r}+\epsilon
$$

d: $M_{r}=$ Hymer Pashigian Measure

\begin{tabular}{lcccccccc}
\hline & 1983 & 1984 & 1985 & 1986 & 1987 & 1988 & 1989 & 1990 \\
\hline$\alpha$ & -5.60 & -4.17 & -3.56 & -3.73 & -3.85 & -4.40 & -4.10 & -4.51 \\
& $(-44.09)$ & $(-25.67)$ & $(-32.01)$ & $(-27.46)$ & $(-39.66)$ & $(-41.51)$ & $(-34.55)$ & $(-28.81)$ \\
$\beta$ & 1.68 & 1.68 & 1.68 & 1.68 & 1.68 & 1.68 & 1.68 & 1.68 \\
& $(0.65)$ & $(0.65)$ & $(0.65)$ & $(0.65)$ & $(0.65)$ & $(0.65)$ & $(0.65)$ & $(0.65)$ \\
\multirow{2}{*}{$\mathrm{SEE}$} & 0.66 & 0.76 & 0.52 & 0.72 & 0.48 & 0.52 & 0.62 & 0.88 \\
$\mathrm{R}_{\text {adj }}{ }^{2}$ & & & & & & & & \\
\hline
\end{tabular}

e: $M_{r}=$ Cable Measure

\begin{tabular}{lcccccccc}
\hline & 1983 & 1984 & 1985 & 1986 & 1987 & 1988 & 1989 & 1990 \\
\hline$\alpha$ & -5.81 & -4.34 & -3.66 & -3.80 & -3.87 & -4.41 & -4.09 & -4.50 \\
& $(-38.64)$ & $(-27.56)$ & $(-36.14)$ & $(-28.94)$ & $(-48.04)$ & $(-45.37)$ & $(-36.44)$ & $(-29.14)$ \\
$\beta$ & 57.19 & 57.19 & 57.19 & 57.19 & 57.19 & 57.19 & 57.19 & 57.19 \\
& $(2.46)$ & $(2.46)$ & $(2.46)$ & $(2.46)$ & $(2.46)$ & $(2.46)$ & $(2.46)$ & $(2.46)$ \\
SEE & 0.66 & 0.75 & 0.54 & 0.72 & 0.45 & 0.55 & 0.64 & 0.88 \\
$\mathrm{R}_{\text {adj }}{ }^{2}$ & & & & & & & & \\
\hline
\end{tabular}

fi $M_{r}=$ Correlation Measure

\begin{tabular}{lcccccccc}
\hline & 1983 & 1984 & 1985 & 1986 & 1987 & 1988 & 1989 & 1990 \\
\hline$\alpha$ & 10.66 & 12.01 & 12.69 & 12.51 & 12.40 & 11.86 & 12.16 & 11.75 \\
& $(1.44)$ & $(1.63)$ & $(1.72)$ & $(1.69)$ & $(1.68)$ & $(1.60)$ & $(1.64)$ & $(1.59)$ \\
$\beta$ & -16.25 & -16.25 & -16.25 & -16.25 & -16.25 & -16.25 & -16.25 & -16.25 \\
& $(-2.19)$ & $(-2.19)$ & $(-2.19)$ & $(-2.19)$ & $(-2.19)$ & $(-2.19)$ & $(-2.19)$ & $(-2.19)$ \\
SEE & 0.66 & 0.75 & 0.52 & 0.71 & 0.43 & 0.55 & 0.64 & 0.88 \\
$\mathrm{R}_{\mathrm{adj}}{ }^{2}$ & & & & & & & & \\
\hline
\end{tabular}

Note.. t-values are denoted in parentheses. 
Table 3.3: Ordinary Least Squares Regressions, 12 Provinces.

$$
D_{r}=\alpha+\beta M_{r}+\epsilon
$$

a: $M_{r}=$ National Average Measure

\begin{tabular}{lrccccccc}
\hline & 1983 & 1984 & 1985 & 1986 & 1987 & 1988 & 1989 & 1990 \\
\hline$\alpha$ & -5.76 & -4.45 & -3.82 & -3.82 & -4.16 & -4.92 & -4.47 & -5.00 \\
& $(-29.87)$ & $(-28.01)$ & $(-28.86)$ & $(-36.31)$ & $(-33.79)$ & $(-29.94)$ & $(-16.79)(-19.70$ \\
$\beta$ & 0.06 & 0.11 & 0.06 & 0.05 & 0.08 & 0.13 & 0.13 & 0.158 \\
& $(1.84)$ & $(4.21)$ & $(4.70)$ & $(4.11)$ & $(4.40)$ & $(4.18)$ & $(2.43)$ & $(3.32$ \\
\multirow{2}{*}{$\mathrm{SEE}$} & 0.47 & 0.40 & 0.38 & 0.30 & 0.31 & 0.36 & 0.54 & 0.52 \\
$\mathbf{R}_{\text {adj }}{ }^{2}$ & 0.18 & 0.60 & 0.66 & 0.59 & 0.63 & 0.60 & 0.31 & 0.48 \\
\hline
\end{tabular}

b: $M_{r}=$ Herfindahl Index

\begin{tabular}{lcccccccr}
\hline & 1983 & 1984 & 1985 & 1986 & 1987 & 1988 & 1989 & 199 \\
\hline$\alpha$ & -4.08 & 2.13 & 2.40 & 0.25 & 0.85 & 2.78 & 0.89 & 1.0 \\
& $(-1.76)$ & $(0.71)$ & $(1.01)$ & $(0.12)$ & $(0.30)$ & $(1.03)$ & $(0.24)$ & $(0.2$ \\
$\beta$ & -6.53 & -28.30 & -27.38 & -17.07 & -21.02 & -32.86 & -22.24 & -24.7 \\
& $(-0.62)$ & $(-2.05)$ & $(-2.47)$ & $(-1.82)$ & $(-1.64)$ & $(-2.65)$ & $(-1.30)$ & $(-1.2$ \\
SEE & 0.53 & 0.56 & 0.54 & 0.42 & 0.46 & 0.45 & 0.63 & 0.6 \\
$\mathbf{R}_{\text {adj }}{ }^{2}$ & -0.06 & 0.23 & 0.32 & 0.17 & 0.13 & 0.35 & 0.06 & 0.0 \\
\hline
\end{tabular}

c: $M_{r}=$ Conroy Portfolio Measure

\begin{tabular}{|c|c|c|c|c|c|c|c|c|}
\hline & 1983 & 1984 & 1985 & 1986 & 1987 & 1988 & 1989 & 1991 \\
\hline$\alpha$ & & & & & & $\begin{array}{c}-4.29 \\
(-12.03)\end{array}$ & $\begin{array}{c}-3.65 \\
(-8.67)\end{array}$ & $\begin{array}{l}-4.1 \\
(-8.8 .\end{array}$ \\
\hline$\beta$ & & & & & & $\begin{array}{c}-0.14 \\
(-0.31)\end{array}$ & $\begin{array}{c}-0.39 \\
(-0.77)\end{array}$ & $\begin{array}{l}-0.3: \\
(0.5)\end{array}$ \\
\hline SEE & & & & & & 0.33 & 0.35 & 0.41 \\
\hline $\mathrm{R}_{\mathrm{gdi}}{ }^{2}$ & & & & & & -0.09 & -0.04 & -0.0 \\
\hline
\end{tabular}

Note: t-values are denoted in parentheses. 
Table 3.3: Ordinary Least Squares Regressions, 12 Provinces (Contimued).

$$
D_{r}=\alpha+\beta M_{r}+\epsilon
$$

d: $M_{r}=$ Hymer Pashigian Measure

\begin{tabular}{lcccccccc}
\hline & 1983 & 1984 & 1985 & 1986 & 1987 & 1988 & 1989 & 1990 \\
\hline$\alpha$ & -5.67 & -5.57 & -4.07 & -3.93 & -4.32 & -4.31 & -3.42 & -5.06 \\
& $(-18.72)$ & $(-6.69)$ & $(-14.30)$ & $(-11.70)$ & $(-28.79)$ & $(-6.31)$ & $(-5.74)$ & $(-14.13)$ \\
$\beta$ & 10.65 & 47.41 & 29.24 & 17.03 & 23.11 & -5.55 & -50.35 & 77.25 \\
& $(0.62)$ & $(1.94)$ & $(2.50)$ & $(1.17)$ & $(4.44)$ & $(-0.12)$ & $(-0.93)$ & $(2.36)$ \\
SEE & 0.53 & 0.57 & 0.54 & 0.46 & 0.31 & 0.59 & 0.65 & 0.60 \\
$\mathrm{R}_{\text {adj }}{ }^{2}$ & -0.06 & 0.20 & 0.32 & 0.03 & 0.62 & -0.10 & -0.01 & 0.29 \\
\hline
\end{tabular}

e: $M_{r}=$ Cable Measure

\begin{tabular}{lcccccccc}
\hline & 1983 & 1984 & 1985 & 1986 & 1987 & 1988 & 1989 & 1990 \\
\hline$\alpha$ & -5.73 & -4.50 & -3.86 & -3.83 & -4.06 & -4.66 & -4.08 & -4.65 \\
& $(-27.47)$ & $(-23.97)$ & $(-23.54)$ & $(-28.85)$ & $(-35.99)$ & $(-13.61)$ & $(-14.86)$ & $(-23.46)$ \\
$\beta$ & 55.06 & 135.72 & 159.32 & 130.61 & 246.22 & 644.95 & 560.76 & 2995.91 \\
& $(1.45)$ & $(3.65)$ & $(3.76)$ & $(3.02)$ & $(4.22)$ & $(0.91)$ & $(0.68)$ & $(2.85)$ \\
\multirow{2}{*}{ SEE } & 0.52 & 0.53 & 0.49 & 0.41 & 0.30 & 0.59 & 0.65 & 0.56 \\
$\mathrm{R}_{\mathrm{ddj}}{ }^{2}$ & 0.09 & 0.53 & 0.54 & 0.43 & 0.60 & -0.02 & -0.05 & 0.39 \\
\hline
\end{tabular}

f: $M_{r}=$ Correlation Measure

\begin{tabular}{lcccccccc}
\hline & 1983 & 1984 & 1985 & 1986 & 1987 & 1988 & 1989 & 1990 \\
\hline$\alpha$ & 12.63 & 17.68 & 86.18 & 67.18 & 37.57 & 76.85 & -128.03 & 177.47 \\
& $(0.18)$ & $(0.71)$ & $(3.07)$ & $(1.75)$ & $(3.10)$ & $(0.53)$ & $(-0.83)$ & $(0.99)$ \\
$\beta$ & -18.22 & -21.96 & -89.94 & -71.05 & -41.50 & -81.31 & 124.06 & -182.09 \\
& $(-0.25)$ & $(-0.88)$ & $(-3.19)$ & $(-1.84)$ & $(-3.41)$ & $(-0.56)$ & $(0.81)$ & $(-1.02)$ \\
SEE & 0.50 & 0.49 & 0.45 & 0.38 & 0.30 & 0.59 & 0.66 & 0.54 \\
$\mathrm{R}_{\text {adj }}{ }^{2}$ & -0.03 & -0.01 & 0.24 & 0.08 & 0.27 & -0.02 & -0.01 & 0.00 \\
\hline
\end{tabular}

Note: t-values are denoted in parentheses. 
Table 3.4: Seemingly Unrelated Regressions, 12 Provinces.

$$
D_{r}=\alpha+\beta M_{r}+\epsilon
$$

a: $M_{r}=$ National Average Measure

\begin{tabular}{lrccccccc}
\hline & 1983 & 1984 & 1985 & 1986 & 1987 & 1988 & 1989 & 1990 \\
\hline$\alpha$ & -5.80 & -4.26 & -3.83 & -3.91 & -4.08 & -4.64 & -4.21 & -4.59 \\
& $(-43.11)$ & $(-34.67)$ & $(-31.91)$ & $(-35.25)$ & $(-43.01)$ & $(-40.02)$ & $(-27.15)$ & $(-28.45)$ \\
$\beta$ & 0.06 & 0.06 & 0.06 & 0.06 & 0.06 & 0.06 & 0.06 & 0.06 \\
& $(6.14)$ & $(6.14)$ & $(6.14)$ & $(6.14)$ & $(6.14)$ & $(6.14)$ & $(6.14)$ & $(6.14)$ \\
SEE & 0.47 & 0.46 & 0.38 & 0.32 & 0.32 & 0.43 & 0.58 & 0.61 \\
$\mathrm{R}_{\text {adj }}{ }^{2}$ & & & & & & & & \\
\hline
\end{tabular}

b: $M_{r}=$ Herfindahl Index

\begin{tabular}{ccccccccc}
\hline & 1983 & 1984 & 1985 & 1986 & 1987 & 1988 & 1989 & 1990 \\
\hline$\alpha$ & -2.58 & -1.09 & -0.60 & -0.57 & -0.82 & -1.46 & -1.03 & -1.41 \\
& $(-2.93)$ & $(-1.24)$ & $(0.69)$ & $(-0.63)$ & $(-0.93)$ & $(-1.66)$ & $(-1.17)$ & $(-1.60)$ \\
$\beta$ & -13.43 & -13.43 & -13.43 & -13.43 & -13.43 & -13.43 & -13.43 & -13.43 \\
& $(-3.38)$ & $(-3.38)$ & $(-3.38)$ & $(-3.38)$ & $(-3.38)$ & $(-3.38)$ & $(-3.38)$ & $(-3.38)$
\end{tabular}

$\begin{array}{lllllllll}\text { SEE } & 0.54 & 0.59 & 0.58 & 0.42 & 0.48 & 0.50 & 0.64 & 0.70\end{array}$

$\mathrm{R}_{\mathrm{adj}}^{2}$

c: $M_{r}=$ Conroy Portfolio Measure

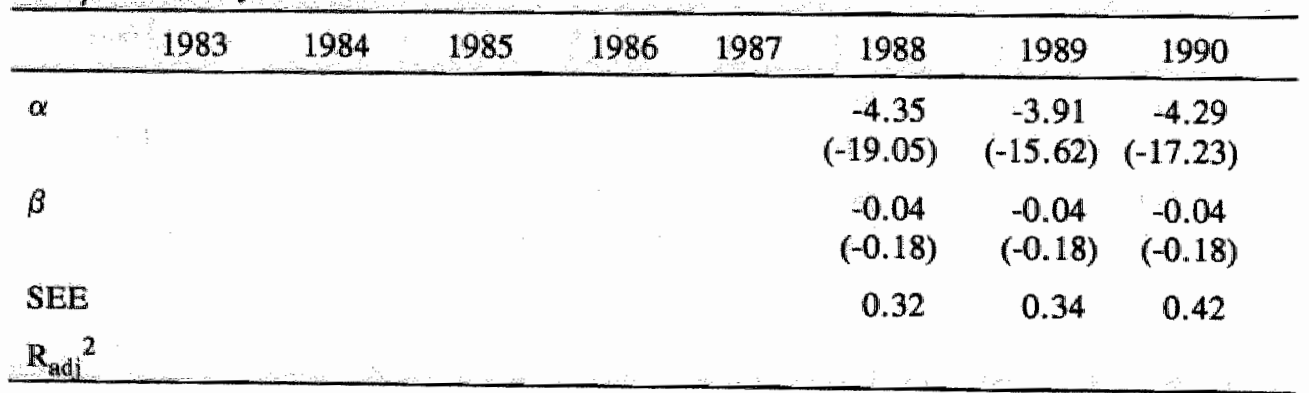

Note: t-values are denoted in parentheses. 
tations. Our regression model seems to be misspecified for that year. The other exception is the results of the Conroy Portfolio measure. The measure either yields a counterintuitive relationship with mortgage default risk, or no significant relationship at all. This is contrary to our expectations, since this was the most successful explanatory variable in previous research (Clauretie, 1988).

\subsection{Conclusions}

In this chapter, we show that regional economic diversity and stability can explain regional mortgage default risk. We find that dynamic measures of stability have more explanatory power of this mortgage default risk than static diversity measures. This has two important implications.

The first is that the relationship between real estate performance and regional economic diversity and stability exists indeed. In Chapter 2, we implicitly assumed such a relationship, without formally testing it. Since our measures of regional economic diversity and stability are based on employment, this implies that employment, and especially changes in employment, can serve as a good indicator of real estate returns. This suggests that real estate diversification decisions can be improved by taking regional employment composition and dynamics into account.

The other implication of our results concerns the Dutch mortgage guarantee system. The current system in the Netherlands has zero insurance premiums. However, there is an ongoing discussion whether to introduce such premiums in the system. Our results suggest that regional economic diversity and stability should be taken into account when determining the premium of the mortgage guarantee.

We now move on to Part Two, in which we are no longer concerned with the regional economics approach, but instead look at international real estate diversification on a country-by-country level. The next three chapters are all concerned with international real estate portfolio diversification through the investment in property shares in different countries and different continents. 
Table 3.4: Seemingly Unrelated Regressions, 12 Provinces (Continued).

$$
D_{r}=\alpha+\beta M_{r}+\epsilon
$$

d: $M_{r}=$ Hymer Pashigian Measure

\begin{tabular}{lcccccccc}
\hline & 1983 & 1984 & 1985 & 1986 & 1987 & 1988 & 1989 & 1990 \\
\hline$\alpha$ & -5.81 & -5.65 & -3.88 & -3.99 & -4.24 & -4.65 & -4.15 & -4.50 \\
& $(-39.13)$ & $(-26.83)$ & $(-25.88)$ & $(-30.52)$ & $(-44.01)$ & $(-28.85)$ & $(-21.91)$ & $(-25.24)$ \\
$\beta$ & 2.24 & 2.24 & 2.24 & 2.24 & 2.24 & 2.24 & 2.24 & 2.24 \\
& $(8.78)$ & $(8.78)$ & $(8.78)$ & $(8.78)$ & $(8.78)$ & $(8.78)$ & $(8.78)$ & $(8.78)$ \\
SEE & 0.54 & 0.60 & 0.55 & 0.46 & 0.31 & 0.60 & 0.71 & 0.69 \\
$\mathrm{R}_{\text {adj }}{ }^{2}$ & & & & & & & & \\
\hline
\end{tabular}

e: $M_{r}=$ Cable Measure

\begin{tabular}{lcccccccc}
\hline & 1983 & 1984 & 1985 & 1986 & 1987 & 1988 & 1989 & 1990 \\
\hline$\alpha$ & -5.88 & -4.34 & -3.70 & -3.75 & -3.89 & -4.42 & -3.96 & -4.33 \\
& $(-34.84)$ & $(-31.56)$ & $(-28.52)$ & $(-37.26)$ & $(-37.79)$ & $(-28.79)$ & $(-22.29)$ & $(-22.37)$ \\
$\beta$ & 92.64 & 92.64 & 92.64 & 92.64 & 92.64 & 92.64 & 92.64 & 92.64 \\
& $(4.68)$ & $(4.68)$ & $(4.68)$ & $(4.68)$ & $(4.68)$ & $(4.68)$ & $(4.68)$ & $(4.68)$ \\
SEE & 0.52 & 0.57 & 0.54 & 0.41 & 0.31 & 0.59 & 0.70 & 0.71 \\
$\mathbf{R}_{\text {adj }}{ }^{2}$ & & & & & & & & \\
\hline
\end{tabular}

f: $M_{r}=$ Correlation Measure

\begin{tabular}{lcccccccc}
\hline & 1983 & 1984 & 1985 & 1986 & 1987 & 1988 & 1989 & 1990 \\
\hline$\alpha$ & 53.87 & 55.08 & 55.82 & 55.68 & 55.45 & 55.02 & 55.48 & 55.10 \\
& $(11.74)$ & $(12.06)$ & $(12.18)$ & $(12.16)$ & $(12.11)$ & $(11.94)$ & $(12.07)$ & $(11.99)$ \\
$\beta$ & -59.46 & -59.46 & -59.46 & -59.46 & -59.46 & -59.46 & -59.46 & -59.46 \\
& $(-12.94)$ & $(-12.94)$ & $(-12.94)$ & $(-12.94)$ & $(-12.94)$ & $(-12.94)$ & $(-12.94)$ & $(-12.94)$ \\
SEE & 0.50 & 0.54 & 0.51 & 0.38 & 0.34 & 0.60 & 0.69 & 0.71 \\
$R_{\text {adj }}{ }^{2}$ & & & & & & & & \\
\hline
\end{tabular}

Note: t-values are denoted in parentheses. 
Appendix 3.A: Division of Economic Activities According to the Dutch Central Bureau of Statistics.

1. Agriculture

Agriculture and horticulture

Forestry

Fishing

2. Mining/Manufacturing

Extraction and briquetting of solid fuels

Extraction of petroleum and natural gas

Other mineral extraction

Food, drink and tobacco industry

Textile industry

Clothing industry

Leather, leather goods and footwear industry

Timber and wooden furniture industries

Manufacture of paper and paper products

Printing and publishing

Oil industry

Chemical industry

Man-made fibres industry

Processing of rubber and plastics

Construction materials, glass industry

Basic metal industry

Manufacture of metal articles

Mechanical engineering

Electrical engineering

Manufacture of means of transport

Instrument and optical engineering

Other manufacturing industries

3. Utility

Public utilities

4. Construction

Building industry

Installing industry 
Appendix 3.A: Division of Economic Activities According to the Dutch Central Bureau of Statistics (Continued).

5. Trades and Tourism

Wholesale distribution

Agents and other trade intermediaries

Retail distribution

Hotels and catering

Repair of consumer goods and vehicles

6. Transport and Communication

Railways

Other land transport

Sea transport and coastal shipping

Inland water transport

Air transport

Supporting services to transport

Communication

7. Finance, Insurance and Real Estate

Banking

Insurance except for compulsory social insurance

Exploitation and trading of real estate

Business services

Rental of machines and other movables

8. Other services

Public authorities, defence and compulsory social insurance

Religious organizations

Education

Medical and other health services, veterinary services

Other services provided to the general public

Social and cultural institutions

Sports and recreation

Research institutions, unions, and other social organizations

Other services 
Appendix 3.B1: The Two Levels of Regional Disaggregation in the Netherlands, Explanation of the Map.

Number on Map Region

North East Groningen

Other Groningen

North Friesland

South Friesland

Drenthe

Twente

Other Overijssel

Veluwe

Arnhem Nijmegen

Other Gelderland

Utrecht

Kop van Noord Holland

Alkmaar Zaanstreek

Haarlem IJmond

Amsterdam

Leiden Bollenstreek

Den Haag

Delft Westland

East Zuid Holland

Rijnmond

South East Zuid Holland

Zeeland

West Noord Brabant

Middle Noord Brabant

Den Bosch

Eindhoven

North Middle Limburg

South Limburg

Polders
Province

Groningen

Friesland

Drenthe

Overijssel

Gelderland

Utrecht

Noord Holland

Zuid Holland

Zeeland

Noord Brabant

Limburg

Flevopolders 


\section{Appendix 3.B2: \\ Regional Disaggregation in the Netherlands}

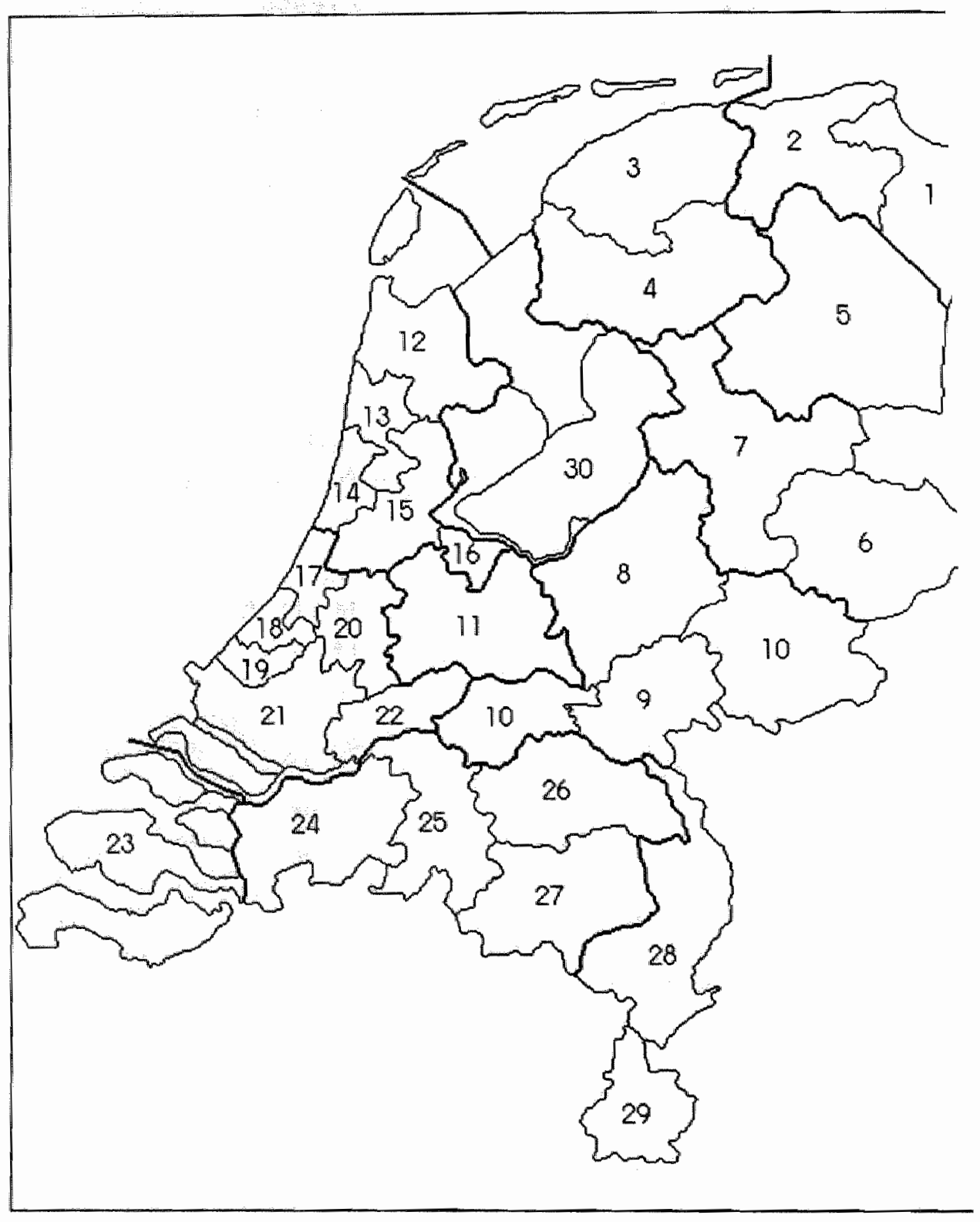




\section{PART TWO}

\section{International Diversification}




\section{Chapter 4 \\ Property Shares, Appraisals and the Stockmarket: An International Perspective}

'At the least sophisticated level of economic theory lies the belief that certain pairs of economic variables should not diverge from each other by too great an extent, at least in the long run.' (Granger, 1986)

In this chapter and in the consecutive ones, we focus on international real estate diversification. We examine its risk reduction potential and explore how this risk reduction can be achieved best. However, doing this is not as straightforward as it is for bonds or stocks, since real estate returns are hard to come by. Real estate is traded infrequently, is not homogeneous and lacks a central marketplace where prices are made public. Researchers have tried to circumvent these problems by using appraisal values to calculate returns on real estate. Especially in the United States, this has led to the emergence of indices based on appraisals of hundreds of commercial buildings. Such appraisal-based indices are also available for Australia, Canada, Hong Kong, and the United Kingdom.

However, broad as the indices may be, they have serious drawbacks. Appraisalbased indices have been reported to be smoothed, to have an inherent time lag (See for example Firstenberg, Ross and Zisler, 1988, or Geltner, 1989b and 1991), and to be biased (Giliberto, 1988, and Geltner, 1989a). These drawbacks are caused by the way the appraisals are conducted. Appraisers take last period's estimated value into account when determining this period's value. This implies that new information is more slowly incorporated into the appraised value than in the true underlying market value, which would bias the appraised value downward in a bull-market and upward in a bear-market. In effect, the appraisal based index behaves like a moving average of past and present values. Furthermore, appraisals are at best conducted quarterly. This also causes the appraisal-based indices to have a time lag.

Appraisal-based real estate returns also have disadvantages of a less fundamental 
nature. Time series of these returns are sometimes available on a monthly basis, like the Investment Property Database index for the United Kingdom, but usually only on a quarterly basis. Another problem of using appraisal-based real estate indices is that they only exist for the five countries mentioned. For this study, in which we are concerned with international real estate portfolio diversification, this constraint is especially limiting. Efforts to start such indices in other countries have occurred, for example in the Netherlands, but the resulting indices do not have a very long history and neither are they very broad based ${ }^{1}$. This has been a major obstacle for real estate research in countries other than the United States and the United Kingdom. It also limits the possibilities of performance measurement of international real estate investments.

Using the returns of publicly traded real estate companies has been proposed as another way to tackle these problems. Especially property shares, the shares of companies of which the sole purpose is to invest in property and to manage a real estate portfolio, look promising as indicators of real estate performance. Since the property shares are publicly traded, even though the underlying real estate is not; the problems of infrequent trading and lack of a central market place seem to be solved ${ }^{2}$. Advantages of property share indices over appraisalbased indices are that they are not smoothed, and do not have an inherent time lag. They also are not biased, even though they might be more volatile due to the closed-end nature of the underlying property shares (Firstenberg, Ross and Zisler, 1988). Furthermore, there is no limit to the frequency of observations in time series of property share returns. Another advantage of property shares is that they exist in many countries. This allows systematic research of the

1. In the Netherlands, several initiatives to start an appraisal-based real estate returns index have occurred. To date, these initiatives have not been successful. The lack of an appraisal-based index in the Netherlands hampers real estate research, even more so since the returns of Dutch property shares are not useful as indicators of Dutch real estate returns. Butch property companies invest mainly abroad. Nevertheless, some information regarding the performance of Dutch real estate exists. Tates and Eichholtz (1993) give sample statistics of the returns of the Dutch real estate portfolio of Aegon, a major Dutch insurance company.

${ }^{2}$ In the United States, property companies of which the purpose is to invest in and manage a portfolio of real estate are generally called Real Estate Investment Trusts (REITs). Since this paper is international in scope, we use the term property companies, even if we refer to United States REITs. 
performance of real estate in countries for which this has been hitherto impossible. It also enables researchers and investors to study international real estate portfolio diversification issues.

All in all, the prospects of property shares as a basis for real estate research seem fertile. Studies of their performance, however, have shown that their returns have a higher contemporaneous correlation with the stockmarket than with the appraisal-based indices (Mengden and Hartzell, 1986) ${ }^{3}$. This has led many researchers to conclude that returns on property shares are bad indicators of real estate returns (See for example Lusht, 1988). However, Giliberto (1990b) and Gyourko and Keim (1992) have found that although property share return indices are contemporaneously related to the stockmarket, they are also related to other real estate indices. Their hypothesis was that the residual of property share returns over stock and bond market returns should be a predictor for appraisal-based returns. Both studies found a statistically significant relationship: property shares can predict the appraisal index. This finding is confirmed by those of Goslings and Petri (1991).

In this chapter, we first perform an international investigation of the relationship between property share indices and the stockmarkets. We do this for twelve countries. For the countries for which we have appraisal-based return indices, the United Kingdom, Hong Kong, Canada, and the United States, we also test the predictive power of the property share return indices on the appraisal index, using error correction or cointegration models. These are developed to model the relationships between variables of which the levels do not diverge too far or too long from each other. Therefore, the relationship between appraisal values and property share values, which are based on the same underlying assets, can probably be well modelled by using error correction or cointegration models.

The remainder of this chapter is as follows. In Section 4.1 the data and the data sources are described. In Sections 4.2 and 4.3 , the relationships between property share return indices and the stockmarket, and between property share return indices and appraisal-based indices, respectively, are investigated. Section 4.4 concludes the chapter.

${ }^{3}$ Liu, Hartzell, Grieg and Grissom (1990) conclude that the market for United States property shares (they use REITs) is integrated with the stockmarket, even though the commercial real estate underlying these property shares is segmented from the stockmarket. 


\subsection{The International Real Estate and Stock Data}

\section{The Appraisal-based Indices}

We have appraisal-based property indices of total returns for Canada, Hong Kong, the United Kingdom, and the United States. They are all quarterly total returns. In Table 4.1 we have included capital values of the indices we use, as well as the time period over which we have the data. Means and standard deviations of the returns are also included. For Hong Kong, we obtained the Property Index - All Properties from the Hong Kong Monthly Digest of Statistics. For the United Kingdom, we use the Total Return Index of Weatherall Green and Smith. For Canada, we use the Russell Canadian Property Index ${ }^{\mathrm{TM}}$, and for the United States, the Russell-NCREIF Property Index ${ }^{4}$. All indices are broadly spread over regions and types of real estate.

\section{The Property Shares}

To compare property shares to the stockmarkets on which they trade, we obtained from Salomon Brothers Inc. time series of total monthly property share index returns for 10 countries: France, Spain, Sweden, the United Kingdom, Australia, Hong Kong, Japan, Malaysia, Singapore, and Canada. Combined, these indices form the Salomon-Russell Global Property Share Index 5 . The period covered is January 1985 through September 1990. For Switzerland, we use the value weighted total return property share index composed by BOPP ISB AG in Zürich, for the same time period ${ }^{6}$. For the United States, we use the index of the National Association of Real Estate Investment Trusts: the NAREIT Index. All indices are in local currency, and observations are based on the last trading day of the month. Table 4.2 gives the market capitalization of

4 The Russell Canadian Property Index ${ }^{\mathrm{TM}}$ is a trademark of the Frank Russell Company. NCREIF stands for National Council of Real Estate Investment Fiduciaries. The Russell-NCREIF Index was previously called Frank Russell Company (FRC) Index.

5 More information about the Salomon Russell Global Property Share Index can be found in Giliberto (1990a).

6 The BOPP ISB AG index is highly representative for the Swiss property share market since it includes the 10 largest Swiss real estate mutual funds. Together, these account for approximately $80 \%$ of the total worth of the 33 Swiss real estate funds (Hoesli and Anderson, 1991). 
Table 4.1: Appraisall-based Indices. Tïme Periods, Market Values at December 1989, and Means and Standard Deviations of Quarterly Returns, Local Currency.

\begin{tabular}{llrrrr} 
Country & Index & Period & Value & $\begin{array}{r}\text { Mearn } \\
\text { Return }\end{array}$ & $\begin{array}{r}\text { Standard } \\
\text { deviation }\end{array}$ \\
\hline United Ringdom & Weatherall, Green \& Smith & $79 / 4-92 / 4$ & 1,256 & 2.68 & 2.53 \\
Hong Kong & Property Index, All Property & $85 / 1-90 / 3$ & - & 7.65 & 5.03 \\
Canada & Russell Canadian Property Index & $\mathbf{8 5 / 1 - 9 0 / 3}$ & 10,292 & $\mathbf{3 . 2 0}$ & 1.74 \\
United States & Russell - NCREIF Property Index & $78 / 1-92 / 4$ & 17,363 & 2.12 & 2.08 \\
\hline
\end{tabular}

Notes: Values are in millions of United States dollars.

A value for the Hong Kong Property Index is not available, since it is an hedonic index, in which the value component in a certain quarter is derived from analysis of all transactions effective in that quarter.

Table 4.2: Property Share Indices. Market Capitalization and Number of Firms at December 1989. Means and Standard Deviations of Monthly Returns, Local Currency, January 1985 - September 1990.

\begin{tabular}{lllrl} 
Country Index & $\begin{array}{c}\text { Value } \\
\text { (Millions US\$) }\end{array}$ & $\begin{array}{c}\text { Number } \\
\text { of Firms }\end{array}$ & $\begin{array}{c}\text { Mean } \\
\text { Rehurn }\end{array}$ & $\begin{array}{c}\text { Standard } \\
\text { deviation }\end{array}$ \\
\hline
\end{tabular}

Europe

$\begin{array}{llrcrr}\text { France } & \text { Sal-Russ* } & 6,289 & 12 & 1.09 & 3.39 \\ \text { Spain } & \text { Sal-Russ } & 589 & 2 & 2.94 & 10.56 \\ \text { Swreden } & \text { Sall-Russ } & 650 & 3 & 2.72 & 7.16 \\ \text { Switzerland } & \text { BOPP ISB } & 4,857 & 10 & 0.61 & 1.80 \\ \text { United } & \text { Sal-Russ } & 14,184 & 22 & 1.07 & 6.86 \\ \text { Kingdom** } & \text { FTA Prop } & 22,554 & 49 & 3.10 & 12.35\end{array}$

Far East

$\begin{array}{lrrrrr}\text { Australia } & \text { Sal-Russ } & 3,194 & 5 & 1.47 & 7.70 \\ \text { Hong Kong } & \text { Sal-Russ } & 6,455 & 9 & 2.78 & 10.91 \\ \text { Japan } & \text { Sal-Russ } & 40,083 & 7 & 2.15 & 13.09 \\ \text { Malaysia } & \text { Sal-Russ } & 738 & 5 & 1.19 & 10.67 \\ \text { Singapore } & \text { Sal-Russ } & 1,499 & 5 & 1.51 & 13.42\end{array}$

North America

\begin{tabular}{llrcrc} 
Canada & Sal-Russ & 896 & 22 & 0.92 & 6.81 \\
United & NAREIT & 11,662 & 118 & -0.22 & 3.21 \\
States & NAREIT & 11,662 & 118 & 1.43 & 6.69 \\
\hline
\end{tabular}

Salomon-Russell Property Share Index.

The second British index is the Financial Times Actuaries Property Share Index. We use quarterly observations from fourth quarter 1979 through fourth quarter 1992.

Both American indices are of the National Association of Real Estate Investment Trusts (NAREIT). The first index is monthly, January 1985 through September 1990, the second index is quarterly, fourth quarter 1977 through fourth quarter 1991. 
each index, the number of firms included in it and the mean and standard deviation of its returns.

The very high returns most indices show can be attributed to the time period chosen. Far East property share indices show monthly standard deviations of over 10 percent, whereas European indices have far lower standard deviations. The exception is Spain, where the property share index has a standard deviation of 10.56 percent.

To compare the property share returns to the appraisal-based returns, we use the Salomon Brothers data for Canada and Hong Kong. For the United Kingdom and the United States, we obtained longer time series of property share returns. For the United Kingdom, we use the Financial Times Actuaries Property Share Index. For the United States, we use the property share index of the National Association of Real Estate Investment Trusts (NAREIT). All these indices report monthly total returns, and to compare them to the appraisal-based returns indices, we construct quarterly indices based on the original indices. Market capitalization, the number of firms included and the mean and standard deviation are also included in Table 4.2.

\section{The Stocks}

Where available, we use the Morgan Stanley Capital International Index. For Singapore, we use the Straits Times Index, and for Malaysia the Emerging Markets Index of the International Finance Corporation. All indices are based on total rates of return. Table 4.3 gives sample statistics of all twelve stockmarket indices. The Canadian and United States stockmarkets appear to be less risky than their European and Far East counterparts.

\subsection{Property Shares and the Stockmarkets}

In this section, we examine the relationship between property share returns and stock returns for twelve countries. Figures 4.1 through 4.6 show graphical representations of the levels of both the stockmarket indices and the property share indices for six countries of our dataset. In general, property shares are closely related to the stockmarket on which they trade. This is especially clear in October 1987. Exceptions are Switzerland, Japan, and France. In these coun- 
Table 4.3: Common Stock Indices. Means and Standard Deviations of Monthly Returns, Local Currency, January 1985 - September 1990.

\begin{tabular}{llll} 
Continent & Country & Mean & Stan \\
\hline Europe & & & \\
& France & 1.55 & 7.13 \\
& Spain & 1.76 & 7.71 \\
& Sweden & 1.74 & 7.08 \\
& Switzerland & 0.87 & 6.20 \\
& United Kingdom & 1.24 & 0.07
\end{tabular}

Far East

$\begin{array}{lll}\text { Australia } & 1.80 & 7.22 \\ \text { Hong Kong } & 2.10 & 8.67 \\ \text { Japan } & 1.01 & 6.36 \\ \text { Malaysia } & 1.12 & 8.19 \\ \text { Singapore } & 1.09 & 8.25\end{array}$

North America

$\begin{array}{lll}\text { Canada } & 0.81 & 4.73\end{array}$

$\begin{array}{lll}\text { United States } & 1.30 & 5.15\end{array}$

Note: All indices are Morgan Stanley Capital International, except for the Malaysian index, which is the Malaysian Emerging Market Index of the International Finance Corporation, and the Singapore index, which is the Straits Times Index.

tries, the property share indices do not show a strong relationship with the stockmarket. In Switzerland, property shares show far less volatility than the stockmarket. There does not seem to be a relationship at all. This can be attributed to the way the market for Swiss property shares works. Swiss property companies are open ended in the sense that their share prices are not determined by the market, but by appraisals of the underlying real estate portfolio performed by the companies. This makes the Swiss property share index more of an appraisal-based index. As for France, common movements between the property share index and the stockmarket clearly exist, but the index volatility is lower than the market volatility. The Japanese property share index, on the other hand, is more volatile than the stockmarket. Especially during the latter half of 1987, when the Japanese stockmarket hardly moved, property share returns were very negative. 
Figure 4.1

Property Shares versus the Stockmarket: France

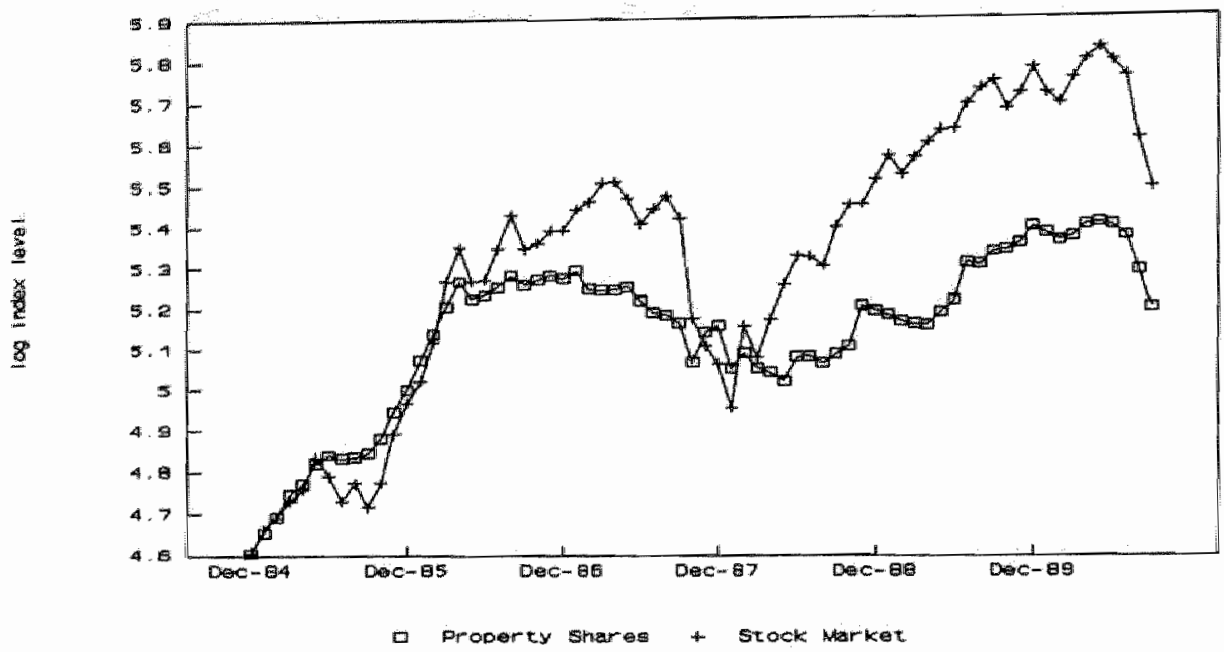

Figure 4.2

Property Shares versus the Stockmarket: Switzerland

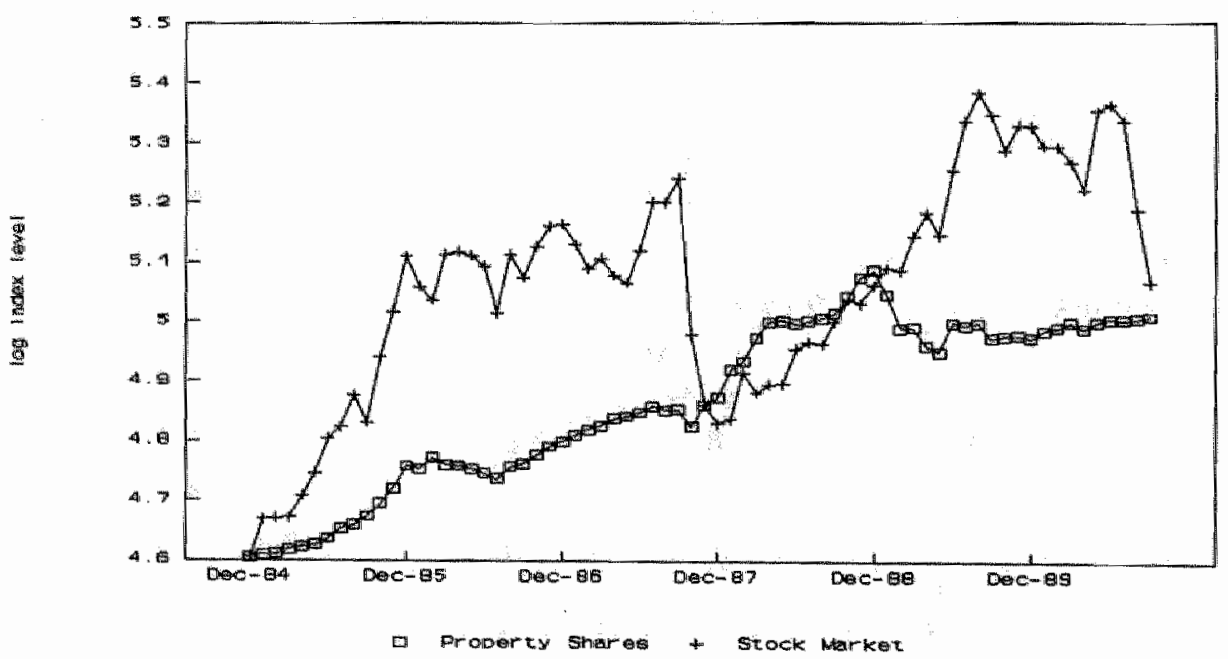


Figure 4.3

Property Shares versus the Stockmarket: United Kingdom

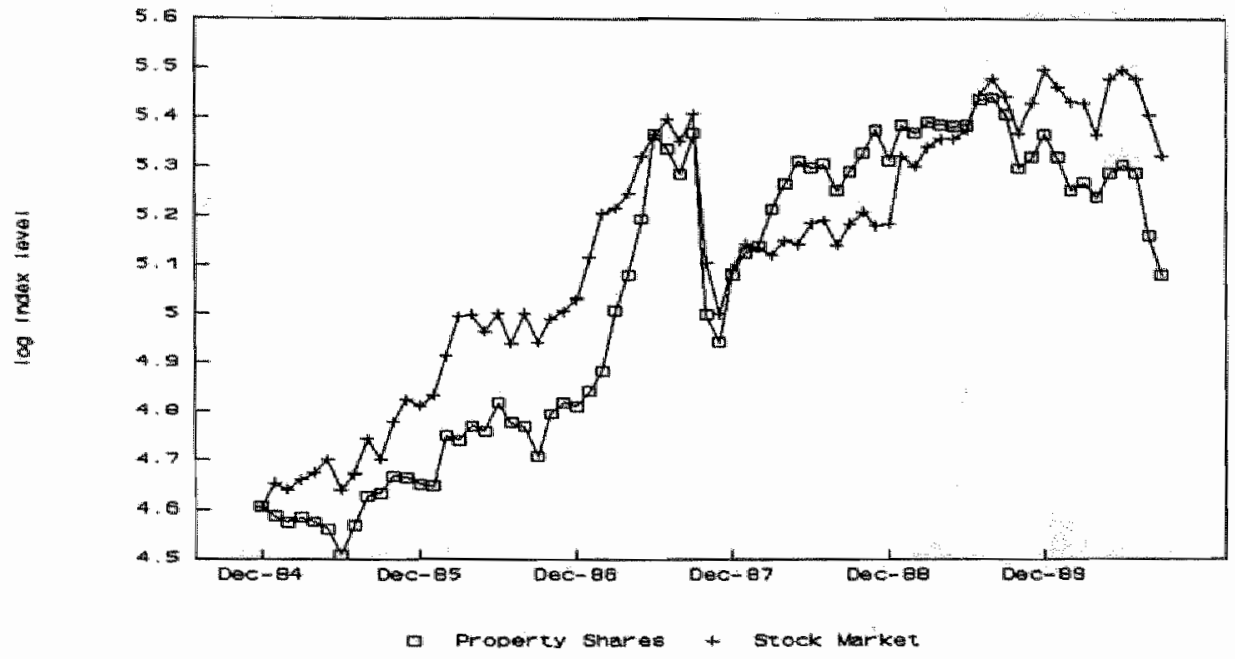

Figure 4.4

Property Shares versus the Stockmarket: Hong Kong

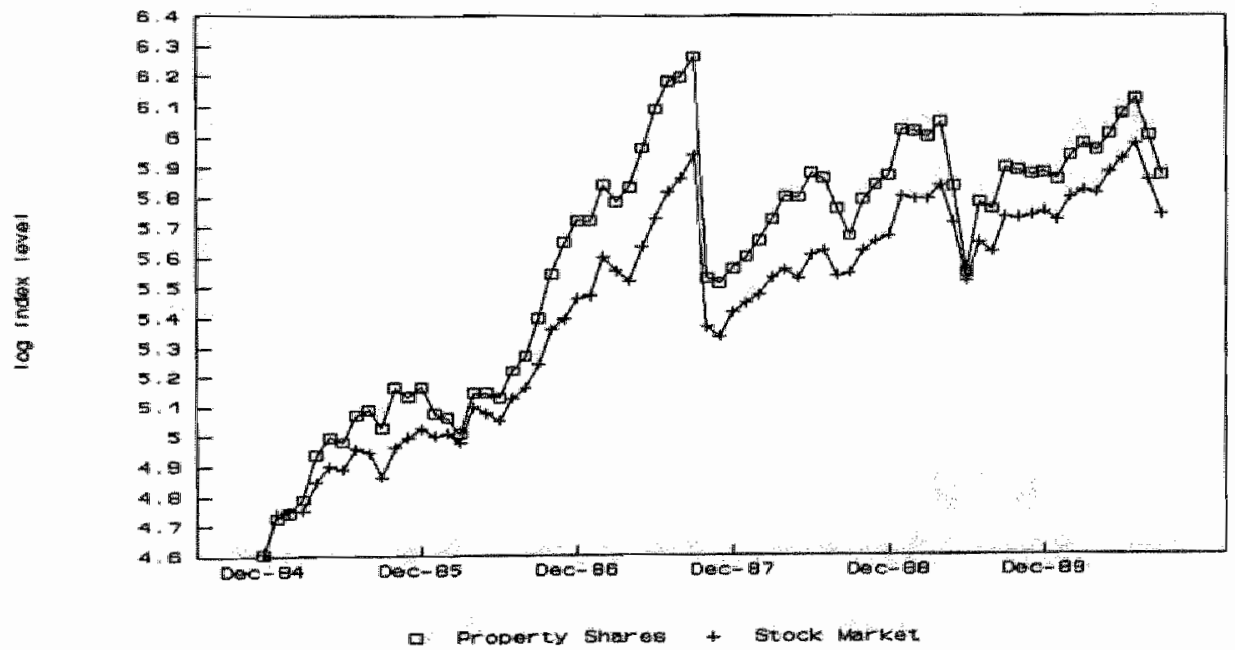


Figure 4.5

Property Shares versus the Stockmarket: Japan

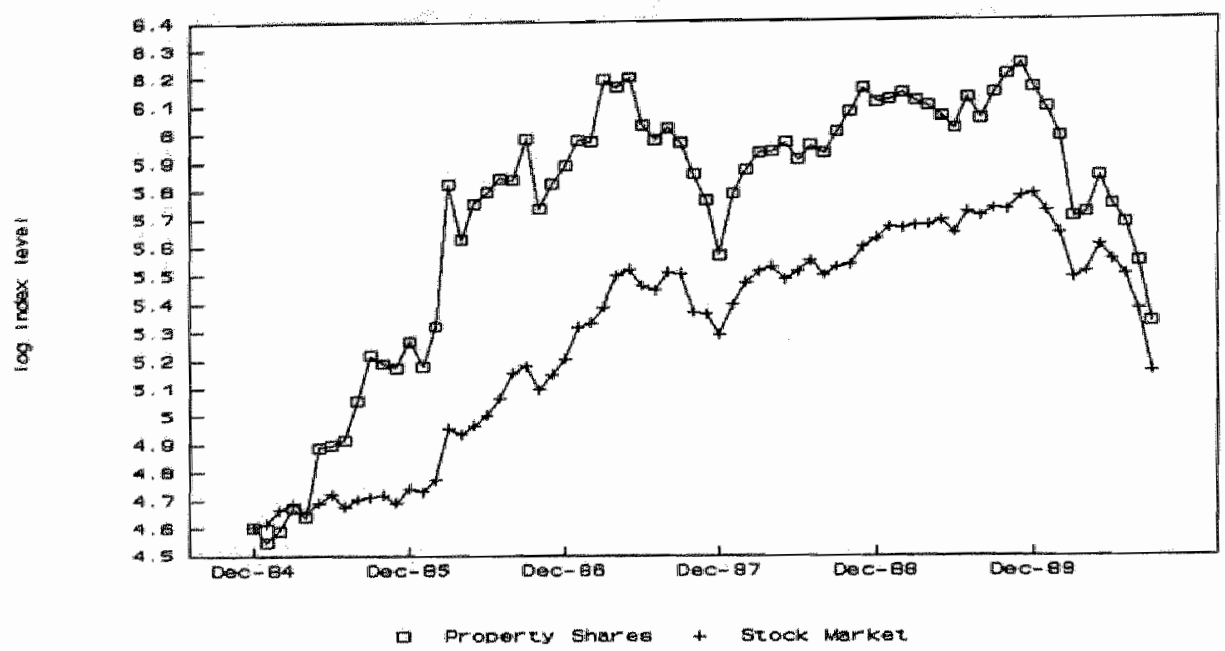

Figure 4.6

Property Shares versus the Stockmarket: Canada

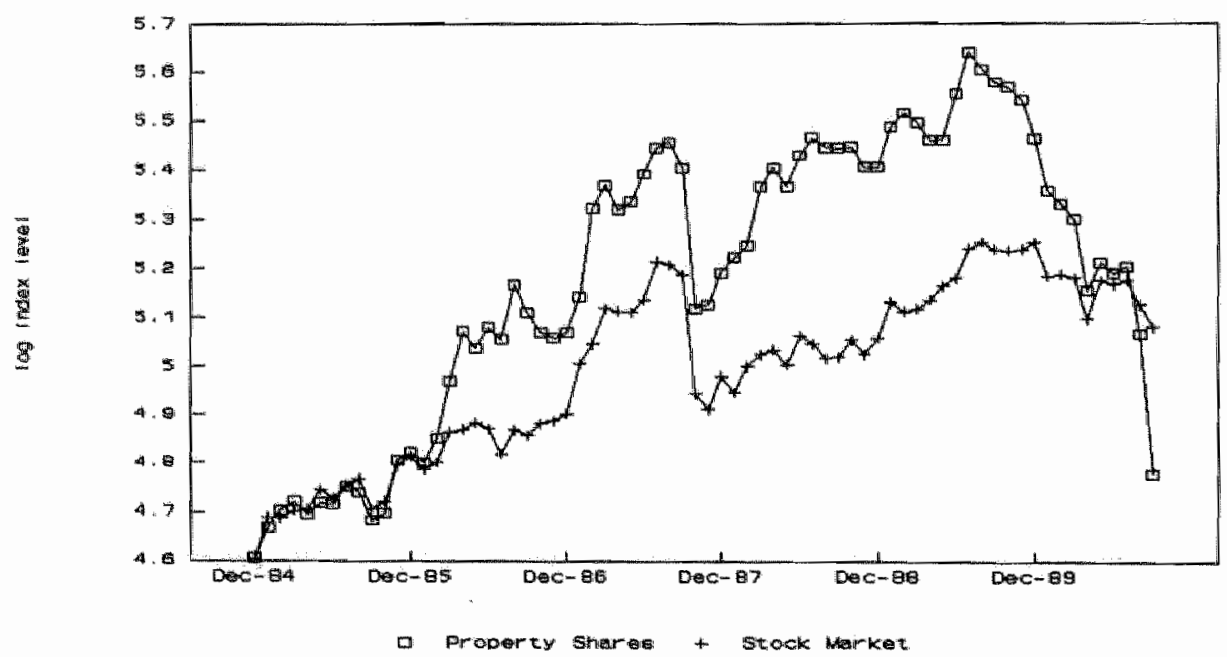


To investigate the relation between the property shares and the stockmarkets further, we regress the monthly property share index returns on a constant and the stockmarket returns: a standard market model. Results are in Table 4.4. The results look similar to those from previous studies for the United States (Mengden and Hartzell, 1986). There is a strongly positive contemporaneous relation of the property shares with their national stockmarkets. The onlyexception to this is Switzerland, probably for the reasons mentioned before. Swiss property shares do not seem to be connected to the Swiss stockmarket at all. The Durbin Watson test statistic indicates for Switzerland the presence of first order autocorrelation in the regression residuals.

The close relationship between property shares and the stockmarkets on which they trade is no surprise, for we would expect real estate and the stockmarket to be related for various reasons. The first is the large real estate component in the value of corporate assets. For the United States, Zeckhauser and Sillverman (1983) estimate the share to be approximately between 25 and 40 percent, while Brueggeman, Fisher and Porter (1990) report that about one third of the total assets of the Fortune 500 companies is real estate. The second reason is that changes in the discount rate and in expectations of long term economic growth are likely to influence both real estate and the value of corporate assets in the same direction. Finally, property shares are included in the stockmarket indices we use. For Hong Kong, for example, their value amounts to roughly 25 percent of the market capitalization of the index.

Looking again at Table 4.4 , we see substantial differences in the property shares' stockmarket betas across countries. This implies that conclusions regarding the riskiness of real estate investments which are based on United States data alone, cannot be generalized to other countries in a straightforward fashion.

Gyourko and Keim (1992) argue that real estate companies' betas should be a decreasing function of the degree of the companies' dependence on the cash flows from tenants in existing properties. The longer the leases of the property in the portfolio, the less dependent rental cash flows are of the business cycle, and the lower the property companies' betas become. For the United States and most European countries, property shares have betas below one. Switzerland has a beta of 0.07 . On the other hand, Far Eastern property share indices have betas higher than one. Especially the Japanese property share index, with a beta 
Table 4.4: Regression Results of Property Share Returns on Stockmarket Returns. Monthly Observations, Local Currency, January 1985 - September 1990.

Country

$\alpha$

6

DW R Radj

Europe

$\begin{array}{lllllll}\text { France } & 0.01 & (0.01) & 0.36 & (0.05) & 1.57 & 0.39 \\ \text { Spain } & 0.01 & (0.01) & 1.04 & (0.12) & 2.14 & 0.52 \\ \text { Sweden } & 0.01 & (0.01) & 0.67 & (0.10) & 2.39 & 0.40 \\ \text { Switzerland } & 0.01 & (0.00) & 0.07 & (0.03) & 1.43 & 0.05 \\ \text { United Kingdom } & 0.00 & (0.00) & 0.91 & (0.09) & 1.95 & 0.63\end{array}$

Far East

$\begin{array}{lllllll}\text { Australia } & -0.00 & (0.00) & 0.89 & (0.07) & 2.09 & 0.73 \\ \text { Hong Kong } & -0.00 & (0.00) & 1.25 & (0.04) & 1.94 & 0.93 \\ \text { Japan } & -0.00 & (0.00) & 1.57 & (0.16) & 2.41 & 0.58 \\ \text { Malaysia } & -0.00 & (0.00) & 1.05 & (0.09) & 1.99 & 0.69 \\ \text { Singapore } & -0.00 & (0.00) & 1.46 & (0.08) & 1.87 & 0.84\end{array}$

North

America

Canad

$-0.00$

$(0.00)$

1.11

(0.11)

1.96

0.61

United States

$-0.01$

(0.00)

0.46

0.57

Notes:

$\beta_{0}$ is a constant, and $\beta_{1}$ is the coefficient reflecting the relationship between property share returns and common stock returns.

DW is the Durbin Watson test statistic for first order autocorrelation in the regression residuals.

Standard deviations of coefficients are denoted in parentheses.

of 1.57 , indicates risky real estate markets. This could be explained by the fact that in Japan investors borrowed against their stock portfolios to partake in the booming Japanese real estate markets of the eighties. An explanation of the high property share index betas for Far Eastern countries in general could be the type of lease contracts used in these countries. If contracts and rents are renewed often, property companies" cash flows are highly dependent on tenants' cash flows and betas should be high. In all 5 Far Eastern countries in our sample, rents and contracts are indeed renewed relatively frequently. In Japan, Hong Kong, and Singapore, contracts typically have a duration of 2 years with fixed rents, with a renewal option at market rents. Malaysian contracts have the 
same renewal option, but have a duration of 3 years. In Australia contracts are for 3 to 5 years, with a market rent review every 2 years. The similarity of the property share index betas within continents could indicate a continental factor in real estate returns: real estate returns in countries within a certain continent show common movements. We do not further investigate this similarity in continental real estate returns in this chapter, but leave that for Chapter 5, to which this phenomenon is central.

\subsection{Property Share and Appraisal-based Returns}

Property share indices have been argued not to be good indicators of real estate returns. This is due to the low contemporaneous correlation they exhibit with other known real estate indicators, usually on an appraisal basis. In this section, we investigate the relationship of property shares with the appraisal-based indices.

Giliberto (1990b) and Gyourko and Keim (1992), and Geltner (1992) show for the United States that property share returns are significantly related to appraisal-based returns. Giliberto regresses the returns of equity property shares on common stock and bond returns, and does a similar regression with the Frank Russell Company (FRC) appraisal-based returns index as the dependent variable. He finds the residuals of these regressions to be positively and significantly correlated. He also regresses the residuals of the FRC appraisalbased returns index on the current and past property share residuals. Fifty percent of the variation of the FRC residual can be explained in this way. This leads him to conclude that these residuals are influenced by a common factor: pure real estate. Thus, property shares are real estate with an important common stock characteristic: liquidity.

Gyourko and Keim argue that even if appraisals are perfectly accurate, changes in real estate market conditions will only slowly be incorporated in the appraisal-based index. One would expect appraisal-based indices to be lagging the underlying value by half the average time interval between two appraisals. The underlying real estate of the Russell-NCREIF Property Index is appraised with frequencies from quarterly to annually. This means one would expect the property share index to lead the appraisal index by an interval of anywhere between six weeks to two quarters. Using quarterly data, therefore, one would 
expect a lead of one or two quarters. Gyourko and Keim test regression models of the Russell-NCREIF residual over the stockmarket on property share, stock, bond, and housing returns. Property share and housing returns appear to be significant predictors of appraisal-based returns.

Geltner proposes an approach to recover the true underlying market returns from appraisal based index returns. His methodology involves a model which relates observed index returns to the unobserved market returns. The model corrects for appraisal smoothing by the appraiser and is thus behavioral in nature. It also corrects the appraisal based index for construction effects of temporal aggregation and seasonality of reappraisals, and is thus also structural in nature. Geltner applies the methodology to the Russell-NCREIF Index and the Evaluation Associates Index and compares the thus obtained estimates of real estate market returns to the unlevered NAREIT index. He finds a close relationship between them, although the NAREIT index is more noisy in the short run and leads the estimated markets values by about a year.

We use a different approach to inquire into the relationship between property share returns and appraisal-based returns. We use error correction models. Before using any statistical tools, however, a look at graphic representations of the property share and appraisal-based indices can be helpful in establishing the relationships between them. Figures 4.7 through 4.10 show graphs of these indices for the four countries for which we have both series: the United Kingdom, Hong Kong, Canada, and the United States. For Hong Kong and Canada, the relationship between the series is not clear. There seems to be a positive relationship, but the time series are too short to infer any long term relationship at all. This is not so for the United Kingdom. The appraisal-based index and the property share index do not diverge to a great extent. Although the appraisal-based index is much smoother than the property share index, a positive relationship obviously exists. For the United States, the indices we use do not follow each other as closely as those for the United Kingdom, but here also, a positive relationship seems to exist. For both the United Kingdom and the United States, downward movements of the appraisal based index clearly lag those of the property share index. Furthermore, these movements are less strong for the appraisal based index than for the property share index.

We now look at the relationship between appraisal-based and property share returns in a more formal way, using error correction models. In our case, the 
Figure 4.7

Property Shares versus Appraisal Index: United Kingdom

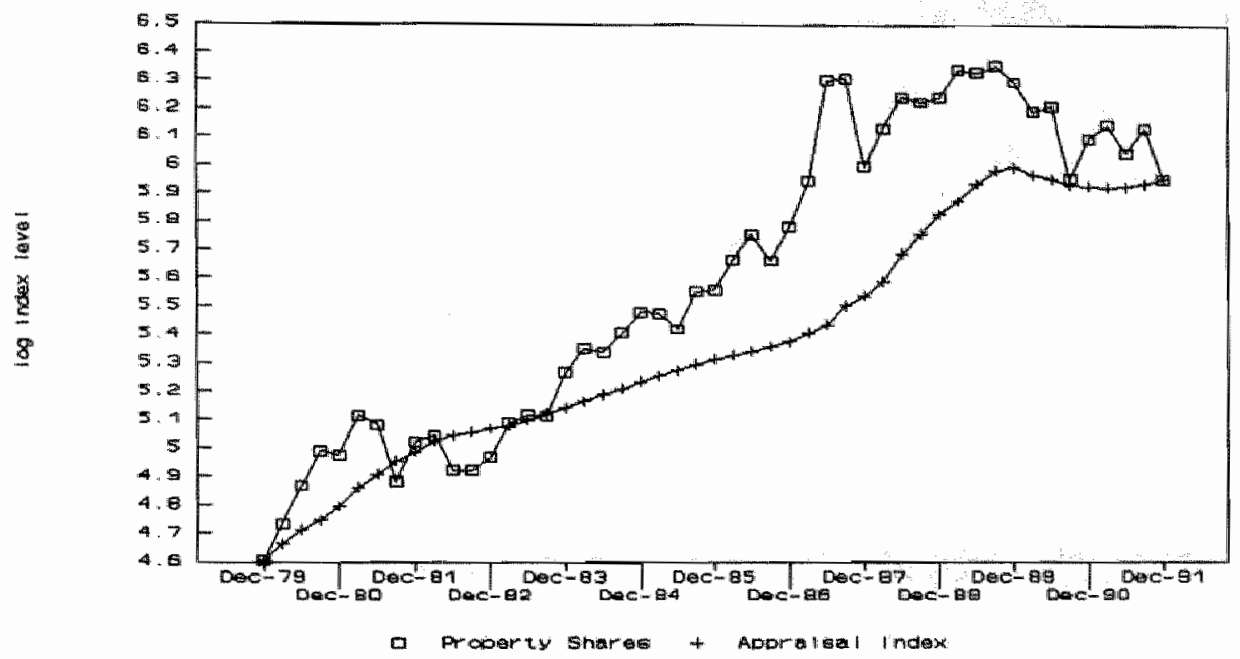

Figure 4.8

Property Shares versus Appraisal Index: Hong Kong

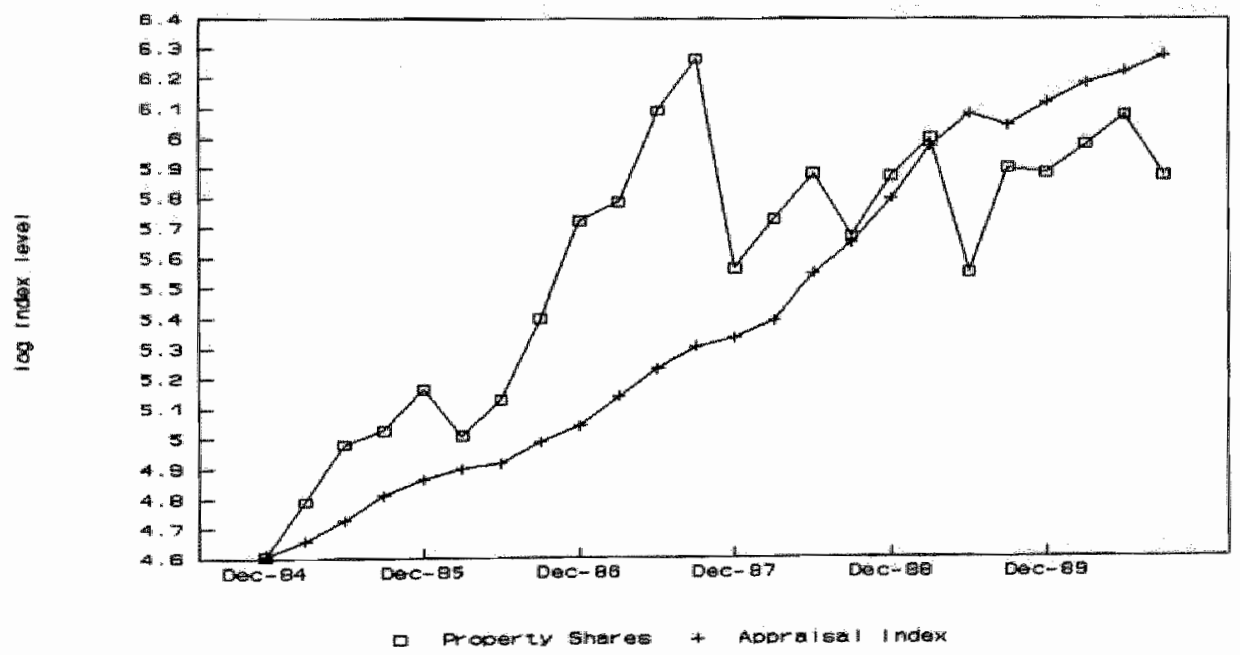


Figure 4.9

Property Shares versus Appraisal Index: Canada

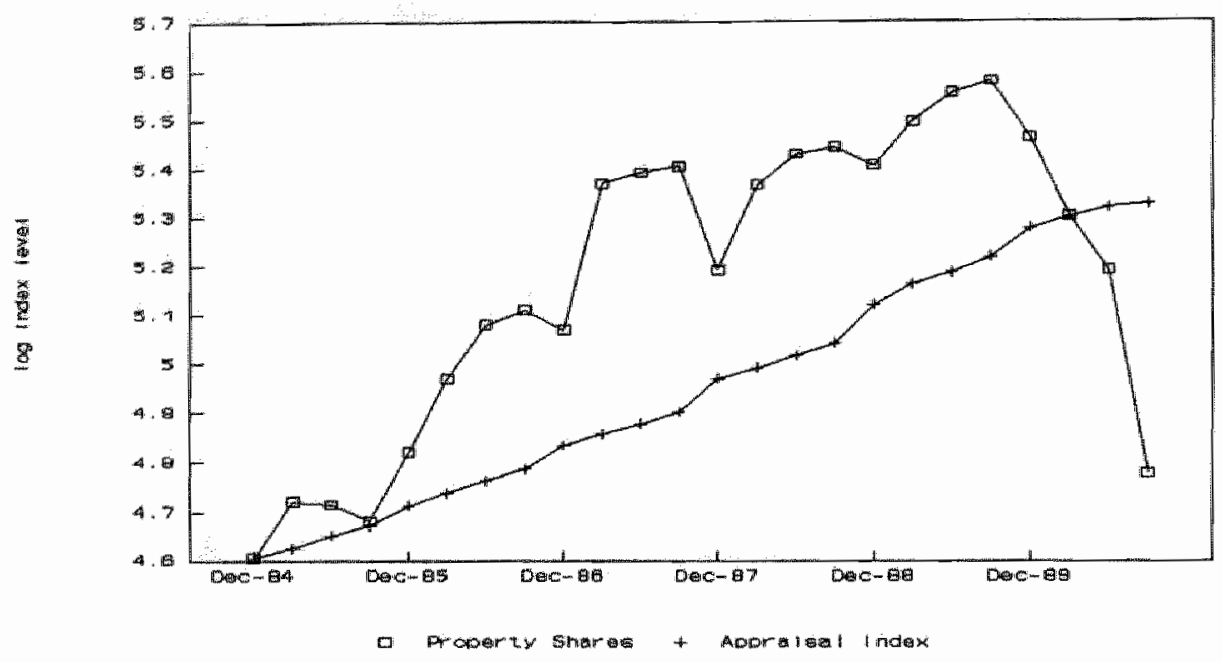

Figure 4.10

Property Shares versus Appraisal Index: United States

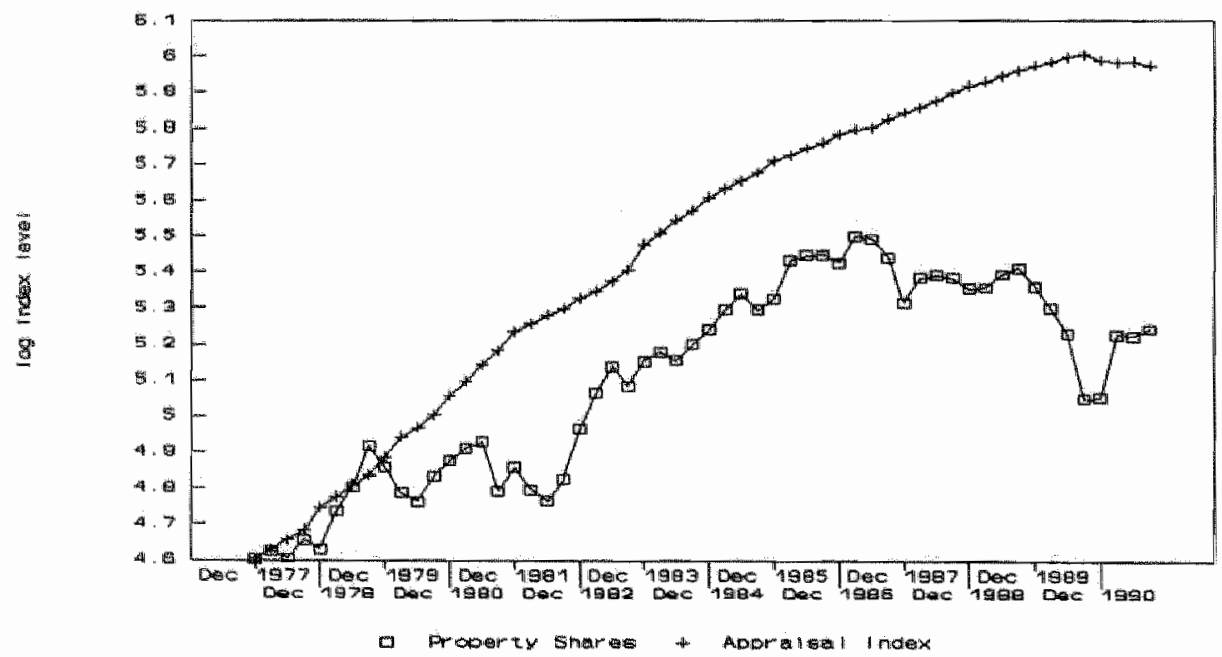


intuition behind using an error correction or cointegration model is that the appraisal value can not diverge too far from the property share value, since they are both based on the same underlying assets. This means that there is a relation between the levels of these series. On the other hand, the levels of the indices are most likely integrated series, although the returns are stationary. This motivates the use of a cointegration or error correction model. The property share index reflects the equilibrium value of real estate. The appraisall-based index can momentarily differ from this value. In the long run, however, it will return to its equilibrium level. The short run error will be corrected ${ }^{7}$. The general form of the error correction model we use is given below.

$$
\begin{gathered}
\ln A_{t}=\gamma_{1} \ln R_{t}+U_{t} \\
\Delta \ln A_{t}=\alpha_{0}+\alpha_{1} \Delta \ln A_{t-1}+\alpha_{2} \Delta \ln A_{t-2}+\alpha_{3} \Delta \ln R_{t-1}+ \\
\alpha_{4} U_{t-1}+\epsilon_{t}
\end{gathered}
$$

where $\gamma_{1}$ reflects the long term equilibrium relationship between the appraisal index level $A_{t}$ and the property share index level $R_{t}$. Since both indices should be equal in the long run, $\gamma_{1}$ equals $1 . U_{t}$ and $\epsilon_{\mathrm{t}}$ are random error terms.

Equation (4.1) is the long run equilibrium appraisal value equation, which says that in the long run, appraised values are driven by the market. The presence of the disturbance term $U_{t}$ in (4.2) implies that actual appraised values can differ from the market. Equation (4.2) describes the short-run behavior of appraisal returns. It has a dynamic error correction form, where $\alpha_{0}$ is a constant; $\alpha_{1}$ and $\alpha_{2}$ measure the extent to which appraisal returns are influenced by their own past; $\alpha_{3}$ reflects the relationship between appraisal returns and past market returns; and $\alpha_{4}$ is the error correction coefficient and measures the response of appraisal returns to disequilibrium in the long term appraised real estate values. This can be seen in (4.3), which is obtained by solving (4.1) for $U_{t-1}$ and then substituting for $U_{t-1}$ in (4.2).

7 An intuitive example of the use of cointegration models can be found in Mehra (1992). 
Table 4.5: Tests of the Cointegration Model. Appraisal-based and Property Share Returns, Local Currency, Quarterly Observations.

$$
\begin{aligned}
\Delta \ln A_{t}=\alpha_{0}+ & \alpha_{1} \Delta \ln A_{t-1}+\alpha_{2} \Delta \ln A_{t-2}+\alpha_{3} \Delta \ln R_{t-1}+ \\
& \alpha_{4}\left(\ln A_{t-1}-\ln R_{t-1}\right)+\mu_{t}
\end{aligned}
$$

\begin{tabular}{|c|c|c|c|c|c|c|c|}
\hline & Period & $\alpha_{0}$ & $\alpha_{1}$ & $\alpha_{2}$ & $\alpha_{3}$ & $\alpha_{4}$ & $\mathbf{R}_{\mathrm{adj}}{ }^{2}$ \\
\hline uk & $79 / 4-91 / 4$ & $\begin{array}{c}0.00 \\
(0.57)\end{array}$ & $\begin{array}{c}0.59 \\
(3.73)\end{array}$ & $\begin{array}{c}0.12 \\
(0.84)\end{array}$ & $\begin{array}{c}0.04 \\
(2.25)\end{array}$ & $\begin{array}{c}-0.02 \\
(-1.43)\end{array}$ & 0.64 \\
\hline hk & $84 / 4-90 / 3$ & $\begin{array}{c}0.06 \\
(1.88)\end{array}$ & $\begin{array}{c}0.33 \\
(1.26)\end{array}$ & $\begin{array}{c}-0.13 \\
(-0.48)\end{array}$ & $\begin{array}{c}0.01 \\
(0.09)\end{array}$ & $\begin{array}{c}-0.01 \\
(-0.20)\end{array}$ & -0.14 \\
\hline cn & $84 / 4-90 / 3$ & $\begin{array}{c}0.04 \\
(3.08)\end{array}$ & $\begin{array}{c}-0.04 \\
(-0.18)\end{array}$ & $\begin{array}{c}-0.35 \\
(-1.61)\end{array}$ & $\begin{array}{c}-0.07 \\
(-1.81)\end{array}$ & $\begin{array}{c}-0.18 \\
(-0.73)\end{array}$ & 0.12 \\
\hline us & $77 / 4-91 / 4$ & $\begin{array}{c}0.03 \\
(3.43)\end{array}$ & $\begin{array}{c}0.29 \\
(2.20)\end{array}$ & $\begin{array}{c}0.22 \\
(1.61)\end{array}$ & $\begin{array}{c}-0.00 \\
(-0.04)\end{array}$ & $\begin{array}{c}-0.03 \\
(-3.34)\end{array}$ & 0.63 \\
\hline
\end{tabular}

Notes: $\quad$ t-values are denoted in parentheses.

$\mathrm{uk}=$ United Kingdom; $\mathbf{h k}=$ Hong Kong; $\mathrm{cn}=$ Canada; $\mathrm{us}=$ United States.

$$
\begin{aligned}
\Delta \ln A_{t}=\alpha_{0}+ & \alpha_{1} \Delta \ln A_{t-1}+\alpha_{2} \Delta \ln A_{t-2}+\alpha_{3} \Delta \ln R_{t-1}+ \\
& \alpha_{4}\left(\ln A_{t-1}-\ln R_{t-1}\right)+\mu_{t}
\end{aligned}
$$

The most common form of estimating the error correction model is after Engle and Granger (1987). It involves a two-step procedure in which first equation (4.1) is estimated to obtain $U_{t}$. Subsequently, the stationarity of $U_{t}$ is examined using a unit root test. Rejection of non-stationarity of $U$, is equivalent to accepting the hypothesis that the variables in (4.1) are cointegrated. In that case, step two is invoked, which involves the estimation of equation (4.2). The alternative is to estimate equation (4.3) directly. We use the direct approach ${ }^{8}$.

8 Boughton and Tavlas (1991) argue that both procedures work equally well. We estimated (4.3) with and without the assumption that $\gamma_{1}$ equals 1 . If $\gamma_{1}$ equals 1 , the regression coefficients of $\ln A_{t-1}$ and $\ln R_{t-1}$, estimated separately, should be equal. We 
Table 4.6: Tests of Granger Causality. Property Share and Appraisal-based Returns, Local Currency, Quarterly Observations.

$$
\begin{aligned}
\Delta \ln R_{t}=\alpha_{0}+ & \alpha_{1} \Delta \ln R_{t-1}+\alpha_{2} \Delta \ln R_{t-2}+\alpha_{3} \Delta \ln A_{t-1}+ \\
& \alpha_{4}\left(\ln R_{t-1}-\ln A_{t-1}\right)+\eta_{t}
\end{aligned}
$$

\begin{tabular}{lccccccc} 
& Period & $\alpha_{0}$ & $\alpha_{1}$ & $\alpha_{2}$ & $\alpha_{3}$ & $\alpha_{4}$ & $R_{\text {adj }}{ }^{2}$ \\
\hline uk & $79 / 4-91 / 4$ & 0.01 & -0.01 & -0.179 & 0.27 & -0.00 & -0.06 \\
& & $(0.44)$ & $(-0.09)$ & $(-1.09)$ & $(0.30)$ & $(-0.00)$ & \\
hk & $84 / 4-90 / 3$ & 0.03 & -0.45 & -0.347 & -0.00 & 0.36 & 0.23 \\
& & $(0.28)$ & $(-2.03)$ & $(-1.57)$ & $(-0.00)$ & $(2.49)$ & \\
cn & $84 / 4-90 / 3$ & -0.01 & -0.27 & -0.206 & -2.46 & 0.46 & 0.34 \\
& & $(-0.10)$ & $(-1.22)$ & $(-0.96)$ & $(-1.85)$ & $(3.01)$ & \\
\multirow{2}{*}{ us } & $77 / 4-91 / 4$ & 0.18 & -0.07 & -0.241 & -2.25 & 0.25 & 0.25 \\
& & $(4.46)$ & $(-0.50)$ & $(-1.91)$ & $(-3.19)$ & $(4.35)$ & \\
\hline
\end{tabular}

Notes: $\quad t$-values are denoted in parentheses. uk = United Kingdom; $\mathbf{h k}=$ Hong Kong; $\mathrm{en}=$ Canada; us = United States.

The results are in Table 4.5. For the United Kingdom and the United States, the model does well. For the United Kingdom the leading property share returns term is significant, while for the United States, the cointegration term is. The autoregressive term in the regression equation has solved the problem of serial correlation in the residuals: using the Lagrange Multiplier test proposed by Godfrey (1978) and Breusch (1978) shows no significant residual serial correlation. Adjusted $\mathrm{R}^{2} \mathrm{~s}$ for these countries are 0.64 and 0.63 , respectively. We can conclude that in the United States and the United Kingdom, appraisalbased returns are determined to a large extent by their own history and the history of the real estate market. Appraisals adjust to market values with a time lag. For Hong Kong and Canada, the results are less clear. The model does not explain the appraisal-based returns to a satisfactory extent. This is probably due to the limited length of the time series we have for both countries.

tested this hypothesis and found that it could not be rejected for any of the four countries. 
We also test the reverse hypothesis that property share returns are determined by their own history and by appraisals. Basically, this amounts to a test of causal direction between the appraisals and the property share returns. We use the Granger causality test (See Granger and Newbold, 1986). The model is:

$$
\begin{gathered}
\Delta \ln R_{t}=\alpha_{0}+\alpha_{1} \Delta \ln R_{t-1}+\alpha_{2} \Delta \ln R_{t-2}+\alpha_{3} \Delta \ln A_{t-1}+ \\
\alpha_{4}\left(\ln R_{t-1}-\ln A_{t-1}\right)+\eta_{t}
\end{gathered}
$$

This model is the exact reverse of the regression model (4.3). Results are in Table 4.6. For the United Kingdom and Hong Kong it is clear that appraisal returns have no predictive power of property share returns. The adjusted $R^{2} s$ are very low for both countries and $\alpha_{4}$ and $\alpha_{5}$ are not significant. Furthermore, for all four countries, we find significant serial correlation in the regression residuals, thus indicating a misspecification of model (4.4). Therefore, we can conclude that in this case, Granger causality is indeed running in one direction: from market values to appraisal values.

\subsection{Conclusions}

The first conclusion concerns the relationship of property share returns indices to appraisal-based return indices. The use of cointegration models shows a significant relationship between property share indices and appraisal-based indices for the United Kingdom and the United States. Appraisal returns appear to be to a large extent determined by their own history and the history of the real estate market. Thus, we have shown that international property shares behave like real estate. This implies that the results of the next two chapters not only apply to property share returns, but to real estate in general.

The second conclusion concerns the relationship property share returns have with their domestic stockmarkets. Except for Switzerland, all national property share returns indices in our dataset show a strong relationship with their stockmarkets, with Asian countries having higher stockmarket betas than European and North American countries. This implies that conclusions from previous research concerning the riskiness of American real estate cannot be extended to international real estate investments without modification. 


\section{Chapter 5 \\ International Real Estate Diversification: By Country or by Continent?}

In Chapter 1, we have seen that portfolio diversification is a key issue for the real estate investor. Both diversification by region and diversification by property type are ways of reducing the risk of the real estate portfolio. For a real estate investor with an international scope, the problem how to optimally allocate investments among countries is added to this. International investing adds risk sources to the portfolio. Examples are the risk of adverse currency fluctuations, the risk that foreign economies are more volatile than the domestic economy, and political risk, for example the chance that foreign properties are nationalized. On the other hand, international investing widens the market portfolio and thus reduces market risk.

Most investors' knowledge of markets is local. Not only does this hold for prices, volumes and investment opportunities, it also holds for many other aspects of a market. To name a few, choosing a broker, speaking the language, knowing legal practices; it is all easier at home than abroad. What it boils down to is that information costs are lower in the home market than in markets far away. For that reason, it makes sense to invest in the home market, or in a market close to it. Also, a trade-off exists between country and political risk on the one hand, and risk reduction by widening the market portfolio on the other hand: For an investor investing only in the home market, country and political risk are low, while market risk is relatively high. Adding countries to the universe increases country and political risk but lowers market risk. If the real estate markets are integrated more within continents than among them, market risk will decrease less if one invests in ones own continent.

A basic question is whether optimal diversification within the international real estate portfolio can be accomplished close to or in the home market. If real estate returns in all countries within one continent move together, this is not the case. Investors have to broaden their scope and include countries in other continents in their spectrum of investment possibilities. On the other hand, if no common trends in real estate returns in countries in a continent exist, one can 
achieve optimal diversification by investing in one's own continent. Thus, a key question is whether a continental real estate return factor exists.

In this chapter, we investigate whether such a factor exists indeed. We analyze real estate return indices for twelve countries from three continents. The methodology we use is a version of principal components analysis which has the advantage of being numeraire independent. This means that the principal components or factors we extract from the returns are not influenced by the choice of the numeraire currency, which is important, since one does not want the composition of groups of countries to be dependent on the currency of measurement.

The chapter proceeds as follows. Section 5.1 describes the data. In Section 5.2, some intuition is given as to why a continental real estate factor can be expected. In Section 5.3, the methodology is presented: generalized numerairefree principal components analysis. The results are presented in Section 5.4, and Section 5.5 gives some conclusions.

\subsection{Property Share Data in United States Dollar Terms}

In this chapter, we use the Salomon Brothers database of international property share returns like we did in Chapter 4. We add for the United States the Wilshire Real Estate Investment Trust Index and for Switzerland the BOPP ISB AG index. Our resulting dataset includes data for Europe, the Far East, and North America. For Europe, we have France, Spain, Sweden, Switzerland and Great Britain. For the Far East, we have Australia, Hong Kong, Japan, Malaysia and Singapore, and for North America we have the United States and Canada. In Table 4.2 in the previous chapter, we have already given sample statistics for this data in local currency terms. Table 5.1 gives the same statistics in United States dollar terms.

Expressed in United States dollar terms, European property shares have performed best in the period under investigation. Their returns have been relatively high, with Sweden and Spain very high at 3.00 and $2.94 \%$ per month, respectively. Risk was highest for Spain. The risk-return trade-off in dollar terms for Far Eastern property shares was less positive in this period. Their returns were on average not as high as in Europe, while they showed a 
Table 5.1: Property Share Indices in United States Dollars. Sample Statistics Based on Monthly Returns, January 1985 - September 1990.

\begin{tabular}{llrrrr} 
& Country & Mean & Std & Min & Max \\
\hline Europe & & & & & \\
& France & 1.73 & 5.90 & -16.29 & 14.27 \\
& Spain & 2.94 & 11.37 & -38.46 & 31.80 \\
Sweden & 3.00 & 6.89 & -10.93 & 16.59 \\
Switzerland & 1.59 & 4.39 & -10.42 & 11.44 \\
& United Kingdom & 1.38 & 8.09 & -31.12 & 16.72
\end{tabular}

Far East

$\begin{array}{lllll}\text { Australia } & 1.10 & 10.13 & -58.11 & 17.17 \\ \text { Hong Kong } & 1.85 & 12.47 & -72.56 & 23.65 \\ \text { Japan } & 1.92 & 13.36 & -34.30 & 50.69 \\ \text { Malaysia } & 0.05 & 11.09 & -37.05 & 30.20 \\ \text { Singapore } & 0.48 & 14.68 & -70.11 & 30.58\end{array}$

North America

\begin{tabular}{|c|c|c|c|c|}
\hline Car & 0.45 & 8.05 & -29.10 & $\begin{array}{r}18.72 \\
7.25\end{array}$ \\
\hline ates. & 0.27 & 4.28 & -20.72 & \\
\hline
\end{tabular}

Note: For Spain the period is June 1985 - September 1990. For Sweden, the period is January 1985 - December 1989.

far higher risk. Property shares in Canada and the United States have been low return/low risk investments in the sample period.

\section{2 \\ The Continental Real Estate Factor}

In this section, we give some intuition as to why continental factors in real estate returns can be expected. Without making any claims of proof of the existence of such factors, we look at economic interdependencies of countries within the three continents in our sample. We first look at international integration of the different capital markets: a stronger degree of international capital market integration within continents than between them would make the existence of continental real estate factors more likely than the absence of 
continental differences in capital market integration. This approach implicitly assumes a supply side relationship between the real estate markets and the economy. Similar reasoning applies to the demand side of the real estate markets. If trade flows are stronger within continents than between them, then a commonality in real estate return movements within continents seems likely.

A determinant of international capital market integration is exchange rate risk. If exchange rate risk within a region is lowered or eliminated because of some type of fixed exchange rate regime, one would expect capital flows across countries in that region to increase and capital markets to become more integrated. The question is thus whether such regimes exist in the three continents we distinguish: Europe, Far East, and North-America. In Table 5.2 the exchange rate regimes for the twelve countries in the dataset are given. In Europe, the European Monetary System (EMS) has been operative since 1979 (Gros and Thygesen, 1992). Until 1989, the EMS currencies were the German Mark, the French Franc, the Dutch Guilder, the Belgian/Luxembourg Franc, the Danish Krone, and the Italian Lira. All these currencies except the Lira were allowed to float within a $2.25 \%$ band from their respective EMS parities. For the Lira, a 6\% bandwidth applied until January 1990. After that month the Lira also had a bandwidth of $2.25 \%$. The Spanish Peseta entered the EMS in June 1989. The British Pound floated free in our sample period. Sweden is not a member of the EC, nor of the EMS, but the Swedish Krone is strongly linked to the EMS currencies nevertheless ${ }^{1}$. Switzerland opted for a free float of the Franc after Bretton Woods (IMF, 1989).

It may be possible that currencies show low exchange rate risk vis-a-vis certain other currencies, whether a formal exchange rate regime exists or not. Table 5.3 shows vollatilities of the changes of the monthly log exchange rates for the

1 In October 1990, just outside our sample period, the British Pound entered the EMS, only to leave the system again in September 1992, together with the Italian Lira. In that month, the EMS was under heavy attack of the foreign exchange markets, and both currencies were withdrawn after massive intervention by the monetary authorities. The Swedish Krone, which had until that month been linked to the European Currency Unit (ECU), started free floating. Before the monetary authorities' decision to opt for a free float of the Krone, Swedish call money interest rates had been as high as $500 \%$ to keep the Krone close to the ECU. In July 1993, the remainder of the EMS was again severely affected by trading on the foreign currency markets. The result was a $15 \%$ bandwidth for the remaining currencies, except for the German Mark/Dutch Guilder rate, for which a bandwidth of $2.25 \%$ is still maintained. 
Table 5.2: Exchange Rate Regimes 12 Currencies. January 1985 September 1990.

$\begin{array}{ll}\text { French Franc } & \text { EMS } \\ \text { Spanish Peseta } & \text { Managed Float; EMS since 6/89 } \\ \text { Swedish Krone } & \text { Pegged to EMS } \\ \text { Swiss Franc } & \text { Free Float } \\ \text { British Pound } & \text { Free Float } \\ \text { Australian Dollar } & \text { Free Float } \\ \text { Hong Kong Dollar } & \text { Pegged to US Dollar } \\ \text { Japanese Yen } & \text { Free Float } \\ \text { Malaysian Ringgit } & \text { Pegged to Basket of Currencies } \\ \text { Singapore Dollar } & \text { Managed Float } \\ \text { Canadian Dollar } & \text { Free Float } \\ \text { American Dollar } & \text { Free Float }\end{array}$

Source: $\quad$ International Monetary Fund (1986 - 1990)

12 currencies relevant to this study. Since each currency is expressed in the 11 other currencies, we have 11 volatilities for each currency. From this table, it is clear that the European currency returns show relatively low volatilities when expressed in other European currencies, and high volatilities when expressed in non-European currencies. This implies that exchange rate risk among the five European currencies we use in this study is relatively low.

No formal exchange rate system exists among the Far Eastern countries. The countries in our sample maintain a variety of exchange rate regimes, as Table 5.2 shows. Contrary to the European case, Far Eastern exchange rate volatilities are not lower when expressed in Far Eastern currency terms than when expressed in terms of non-Far Eastern currencies. Three of the five countries 


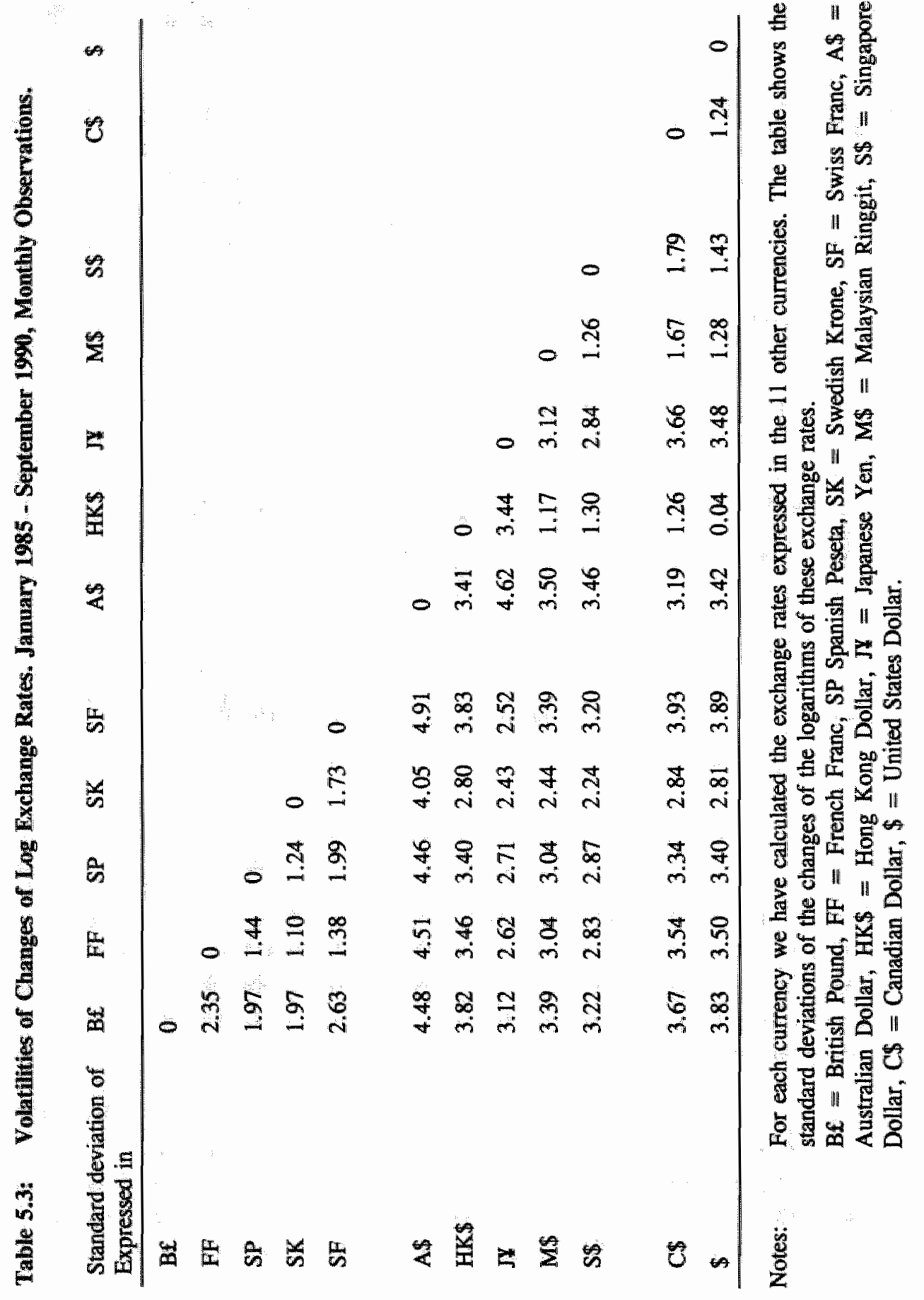


appear to be linked to the US dollar. Malaysia, Singapore, and especially Hong Kong show very low vollatilities when expressed in US dollar terms. Finally, North-America has floating exchange rates, but the Canadian dollar closely follows the US dollar (IMF, 1989). This is easily seen in Table 5.3. Expressed in each other, the US and Canadian dollar show a very low volatility. Expressed in other currencies, these volatilities are much higher.

Thus, it is clear that countries within a continent can show similar exchange rate movements, whether a formal exchange rate regime exists or not. One explanation for this is that countries belonging to the same continent are closely connected through trade. Also, even if we have floating exchange rates, the monetary authorities intervene to maintain orderly market conditions. This is generally undertaken with the United States dollar as the predominant intervention currency.

The low exchange rate volatilities within continents make a higher degree of capital market integration within continents more likely than between continents. A second feature of integrated capital markets is the lack of institutional barriers to international capital flows. In general, these barriers have been reduced in the last decades. What matters here is whether these barriers are higher among than within the three continents we distinguish. Again we start with the European situation. From 1960 onward, barriers to capital movements between the member states of the European Community have been lowered stepwise (Benink, 1993). Inter-country real estate investments in the Community have been free of barriers since 1960 . Spain became a member of the European Community at January 1, 1986. Real estate investments from other European countries in Spain were free of barriers since that date. Real estate investments in other European countries by Spanish citizens were free from January 1, 1991 (Commission of the European Communities, 1988). Sweden and Switzerland are both members of the Organization for Economic Cooperation and Development (OECD), and as such adhere to the Code of Liberalization of Capital Movements of that organization. Subject to this Code international real estate transactions, both by residents in other member countries, and by non residents in the country concerned, are completely free (OECD, 1992). For the Far Eastern countries in our dataset the OECD provisions hold for Japan and Australia. Malaysia maintains certain restrictions to cross border investments, but these do not differ with respect to foreign countries. Hong Kong and Singapore have no restrictions whatsoever concerning cross border real estate 
investments. Canadian international real estate investments are unrestricted. The same holds for the United States? ${ }^{2}$.

All in all, the degree of institutional capital market integration within continents does seem to be somewhat stronger than between continents. We now have to look at trade. The question is whether countries within continents trade more with each other than with countries from other continents. We first look at the existence of institutional barriers to trade.

Institutional trade barriers between national markets have been lowered since the second world war, mainly through the General Agreement on Tariffs and Trade (GATT). However, they have not been lowered to the same extent among all countries. Trade blocs exist. The main example of such a trade bloc is the EC. Barriers to trade in goods and services in the EC have been all but eliminated. Sweden and Switzerland are not members of the EC, but of the European Free Trade Association (EFTA). The EC and the EFTA maintain an industrial free trade area among them (Fieleke, 1992). The foreign trade of Hong Kong, Singapore, and Australia is virtually unrestricted. Malaysia and Japan have foreign trade restrictions which do not differ vis-a-vis the individual countries in our dataset. Between the United States and Canada, the CanadaUnited States Free Trade Agreement has been effective during our complete sample period.

The relationship between the existence of trade barriers and actual trading is not perfect. Trading may go on despite barriers, and a lack of barriers between two countries does not necessarily imply abundant trading. Therefore, we not only examine institutional barriers to trade, but also the actual trading going on among the countries in our sample. In Table 5.4, we have included for each country the exports to the eleven other individual countries as a percentage of total exports to the countries in our sample. European countries tend to trade among themselves, although the United Kingdom also trades a lot with North America. Of the five Far Eastern countries, Japan and Hong Kong trade mostly with North America, but for the other three countries trade within the Far East predominates. For Canada, the United States is by far the most important trading partner, but the foreign trade of the United States is roughly equally

${ }^{2}$ In some states in the United States, investments in land by foreign nationals is restricted (IMF, 1989). 


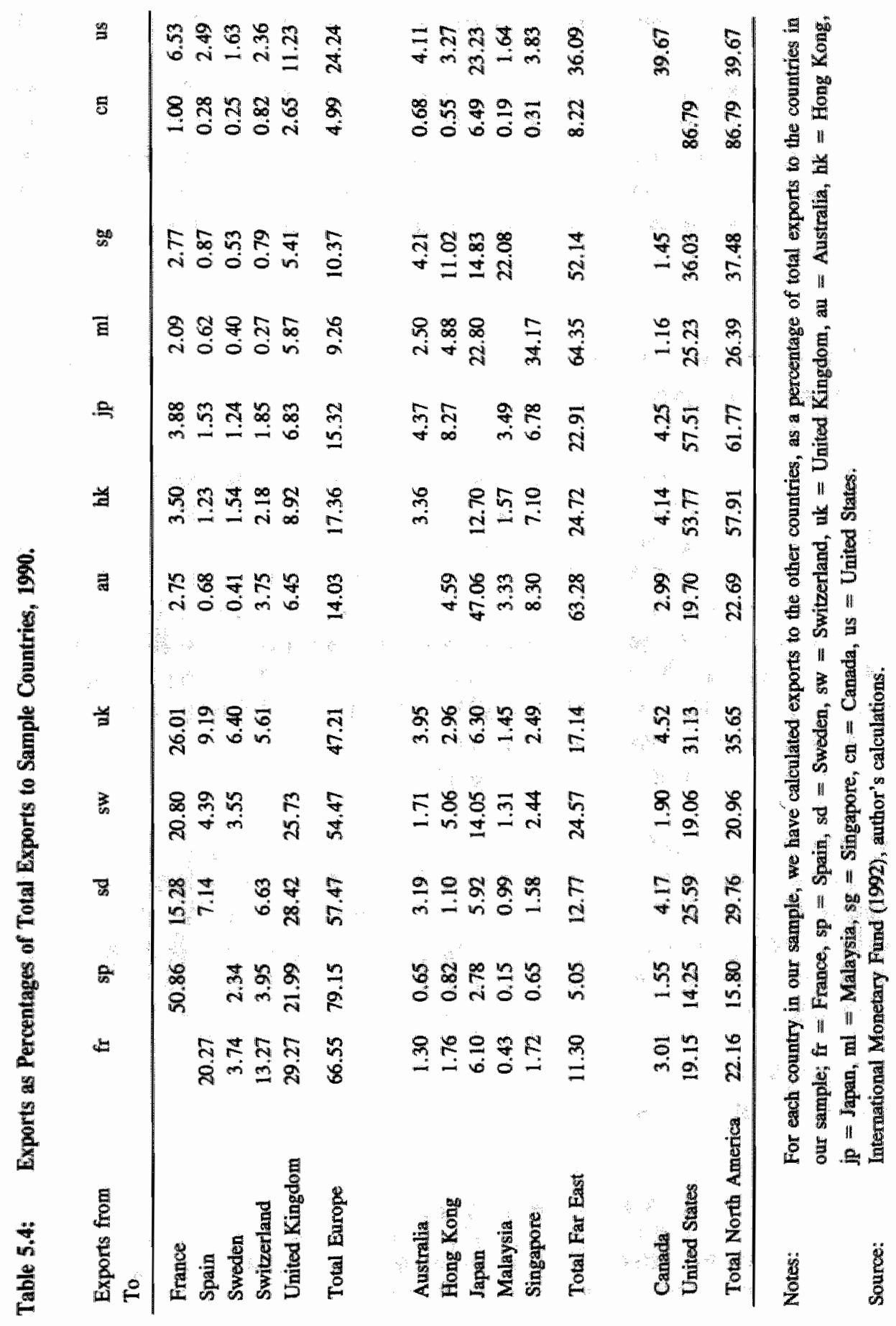


diwided over the three continents we distinguish.

As a preliminary conclusion, we can say that trade flows indeed more or less follow continental patterns, and that boundaries to capital flows largely follow continental borders. However, the question remains if real estate markets are internationally integrated or segmented, and if a continental real estate factor exists. In the remaining sections of this chapter we look at this problem in a more formal way.

\subsection{Methodology: Generalized Numeraire Free Principal Components Analysis}

Empirical applicability of international asset pricing models has been hampered by the numeraire dependency of these models. For example, the lack of success of the International Capital Asset Pricing Model, developed by Solnik (1974a) and Adler and Dumas (1983), is largely due to the fact that the market portfolio is not efficient for investors denoting returns in different currencies. Testable restrictions cannot be formed in such a case. In contrast, the success of the International Arbitrage Pricing Theory can be mainly attributed to the alleged numeraire independence - see Solnik (1983), Cho, Eun and Senbet (1986), and Ikeda (1991). However, this required independence poses severe restrictions on the factor structure resulting from the model ${ }^{3}$.

Chamberlain and Rothschild (1983) have found that principal components analysis can be used for finding an approximate factor structure. Principal components analysis is computationally and conceptionally simpler than factor analysis. However, the factor model they approximate is national in scope. The applicability of this result in an international framework is hampered by the fact that traditional principal components analysis is numeraire dependent.

Koedijk and Schotman (1989), henceforth called KS, have proposed a modified version of principal components analysis to circumvent this problem. They have

${ }^{3}$ Solnik (1983) derives a riskless portfolio by assuming that currency fluctuations have the same factor structure as asset returns expressed in numeraire terms. Ikeda (1991) shows that by expressing returns in local currencies, it is possible to construct an arbitrage portfolio that hedges against exchange rate risk. 
applied their method to exchange rates, i.e. simple returns. If one wants to analyze compound returns, i.e. asset returns from different countries expressed in one numeraire currency, a modification is needed. This can be easily seen if we look at the transformation of compound returns from one numeraire to another. We have a series of logarithmic returns $r_{k j}$ of some asset in country $j$, expressed in currency $k$. We also have $x_{k i}$, the logarithmic exchange rate return of currency $i$ against the numeraire $k$. Then, the transformation if we go from numeraire $k$ to $i$ is

$$
r_{i j}=r_{k j}-x_{k i}, \quad i, j, k=1, \ldots, n \text {. }
$$

KS use simple logarithmic exchange rate levels. However, their transformation is also valid for simple logarithmic exchange rate returns. Therefore, a change in numeraire amounts to

$$
x_{i j}=x_{k j}-x_{k i}
$$

To derive the principal components, we have to write transformations (5.1) and (5.2) in matrix notation. We will now develop our generalized numeraire free principal components analysis.

\section{Derivation}

We have $n$ countries and $n$-1 univariate time series $\left\{x_{t}\right\}_{t=1}^{T}$ of logarithms of exchange rates expressed in some common numeraire currency. Thus, we have a $T \times(n-1)$ data matrix. We can transform $X$ into its principal components matrix $Z$, which has equal dimension. The transformation has three conditions.

$$
\begin{gathered}
Z=X Q B \\
Z^{\prime} Z=\Lambda \\
B^{\prime} Q B=I .
\end{gathered}
$$


In the first condition, $Q$ is positive definite symmetric and $B$ non-singular. The positive-definiteness is required for the interpretation of the principal components. The first condition guarantees that the transformation from $X$ to $Z$ is linear, since $Q$ is an $(n-1) \times(n-1)$ scaling matrix and $B$ is an $(n-1) \times(n-1)$ matrix containing factor loadings. In the second condition, $\Lambda$ is an $(n-1) \times(n-1)$ diagonal matrix. The elements of $\Lambda$ are in descending order of magnitude. Since they determine the variance of the principal components, the first principal component has the highest variance. The third condition is a normalization to set the scale of $X$.

From conditions (a) through (c), we can derive the eigenvalue problem we have to solve in order to find the principal components matrix $Z$. The eigenvalue problem is

$$
\left(Q^{1 / 2} X X Q^{1 / 2}\right)\left(Q^{1 / 2} B\right)=\left(Q^{1 / 2} B\right) \Lambda
$$

where $Q^{1 / 2} Q^{1 / 2}=Q$. Equation (3) shows that the components depend on the choice of $Q, Q$ is not determined in the principal components analysis, but must be specified a priori. In conventional principal components analysis, $Q$ is usually diagonal with elements $q_{i i}=1 / s_{i j}$, where $s_{i i}$ is the sample variance of time series $x_{i}(i=1, \ldots, n-1)$. In other words, all variables are normalized. Once $Q$ has been specified, there exists only one matrix $B$ of factor loadings satisfying conditions (a) through (c) and the transformation from $X$ to $Z$ is unique.

So far, what we have described does not diverge from conventional principal components analysis. The main innovation of the modified version as proposed by $\mathrm{KS}$ is in the choice of $Q$. Instead of choosing it as we described above, it is chosen such that the component matrix $Z$ is independent of the numeraire currency. To find a suitable matrix $Q$, they first look at the effect of a change in the numeraire currency.

Let $x_{k j}$ be the logarithm of the exchange rate of currency $j$ against the numeraire currency $k$. Choosing currency $i$ as the numeraire instead of $k$ gives the transformation

$$
x_{i j}=x_{k j}-x_{k i} \quad(j \neq k),
$$




$$
x_{i k}=-x_{k i}
$$

In matrix notation this transformation becomes

$$
x^{1}=P x^{0}
$$

with $P$ an $(n-1) \times(n-1)$ matrix

$$
P=\left[\begin{array}{cc}
-1 & 0^{\prime} \\
-\iota_{n-2} & I_{n-2}
\end{array}\right]
$$

in which $t_{n-2}$ is a vector of ones of length $n-2, I_{n-2}$ is the identity matrix of rank $n-2$. The $(n-1) \times 1$ vectors $x^{0}$ and $x^{1}$ contain exchange rates expressed in the original and new numeraire currency, respectively. In order to keep notation simple, KS have re-arranged the order of exchange rates such that currency 1 becomes the new numeraire. The transformation matrix $\mathrm{P}$ they use can only be employed in the case of simple returns.

The returns this study is concerned with are compound returns. A real estate investor in a particular country expresses foreign real estate returns in his own currency. Using these compound returns makes the transformation more complicated, since it now involves interactions between exchange rates and real estate returns. This means that $P$ has to be altered to incorporate this effect. In the case of compound returns, let $r_{k j}$ be the logarithm of the real estate index return in country $j$, expressed in currency $k$. The transformation from numeraire currency $i$ to numeraire currency $k$ now amounts to

$$
r_{i j}=r_{k j}-x_{k i} \quad(j \neq k)
$$

From equation (5.6) we can immediately see that the transformation now involves both real estate and exchange rate returns. The derivation of the principal components requires this to be written in matrix notation. Define the vector of returns expressed in numeraire currency 0 as $\left(x^{0,}, r^{0},\right)^{\prime \prime}$ and the 
equivallent vector in numeraire currency 1 as $\left(x^{1}, r^{1} \text {, }\right)^{\text {r }}$. In these vectors $x$ has a length of $n-1$ and $r$ has a length of $n$. The transformation in matrix notation is now

$$
\left[\begin{array}{l}
x^{1} \\
r^{1}
\end{array}\right]=P\left[\begin{array}{l}
x^{0} \\
r^{0}
\end{array}\right],
$$

with the $(2 n-1) \times(2 n-1)$ transformation matrix $P$.

$$
P=\left[\begin{array}{cc}
-1 & 0^{\prime} \\
-\nu_{2 n-2} & I_{2 n-2}
\end{array}\right]
$$

Note that this matrix is analogous to the transformation matrix $P$ in (5.5). The only difference is the dimension of the matrix. The extension of the matrix is caused by the inclusion of the real estate returns. In this setup exchange rates play a double role. In the first place, exchange rates are transformed themselves. Secondly, the $n$ asset returns are transformed by exchange rates.

KS proceed to derive the conditions under which a change in the numeraire currency does not affect the components structure. ${ }^{4}$. In our case these conditions are identical, since the derivation only depends on the form of the transformation matrix.

\section{Interpretation}

Denominating the real estate returns in local currency terms implies that the portfolio currency risk is fully hedged. This must hold for investors from any country. Going from local currency to an arbitrary numeraire currency implies that the fully-hedged portfolio becomes a non-hedged portfolio. Of course, this step must alter the inferences from models concerning the pricing of these assets. On the other hand, expressing the portfolio returns in another arbitrarily chosen numeraire should not change these inferences. Therefore, a critical test

4 The derivation of these conditions rests on the existence of a matrix $Q$ such that $Q$ $=P^{\prime} Q P$. Since $Q$ is positive definite symmetric, this condition can always be met. 
for any international asset pricing model is that its results are numeraire invariant. Such a model could be based on the generalized numeraire free principal components analysis.

In this chapter, we are interested in the question whether real estate markets are internationally segmented along boundaries of continents. Or, to put it another way, to see if real estate markets show common, regional, movements. For this goal, generalized numeraire free principal components analysis is ideally suited. Using this methodology, we can determine the principal components generating the real estate returns. Correlating these components with the original time series of returns expressed in a certain numeraire currency gives an indication of the relative importance of the components in explaining the original return series.

\subsection{Classifying International Property Investments}

In this section, we present the results of the principal components analysis of international real estate returns. We first consider the situation in which the property share index returns are expressed in local currency. Second, we investigate the component structure of currency returns, and finally we combine real estate returns and exchange rate returns, and investigate the component structure of real estate returns expressed in common numeraire currencies.

If real estate returns are expressed in local currency, we have the situation as if the real estate returns were fully hedged against currency risk $^{5}$. Table 5.5 shows the results for this case. The upper part of this table gives the variance of the first four principal components as well as their individual and combined goodness of fit. The first four components together explain $84 \%$ of the total variance of the international property share indices ${ }^{6}$. The second part of the table gives the squared correlations between the first four components and the property share index returns of the twelve countries. The interpretation of the

5 In this case, the numeraire invariancy of the principal component methodology is irrelevant. Therefore, we use standard principal component analysis, in which matrix $Q$ is the unity matrix.

6 Since the other eight components explain only $16 \%$ of the variance of the property share indices, we have not presented them here. 
principal components relies on the correlation between real exchange rates and the first four components. The lower part of the table reports the squared correlations between the first four components and the corresponding real estate return in local currency. Individual correlations exceeding the average fit of the principal component under consideration are printed in bold characters and are the main focus of discussion.

From Table 5.5, we can infer that the correlation structure of the property share index returns shows common traits within continents. Continental Europe's real estate markets, with the exception of Spain, are not strongly influenced by any of the four principal components if we express the real estate returns in local currency. This also holds for the North American countries. Canada and the United States nevertheless show a strong similarity in their correlations to the four components. The Far Eastern countries are strongly influenced by the principal components. Their returns are mostly explained by the first and third components. The first component can be associated with the Far East: Australia, Hong Kong, Malaysia, and Singapore, although this component also highly correlates with the United Kingdom and the United States. The third component also mostly explains Asian real estate return variance. The second component appears to be a Japanese phenomenon, which is indicated by the exceptionally high correlation between this component and Japanese real estate returns. The idiosyncratic behavior of the Japanese real estate markets during our sample period probably accounts for this. The fourth component can be identified as Spanish.

Next, we investigate the component structure of the currency returns. The upper part of Table 5.6 shows the overall fit of the first four components. Combined, they explain $90 \%$ of the total variance of the exchange rate returns. Panels a-c report the squared correlation between the first four components and the corresponding underlying exchange rates versus each of the benchmark currencies in turn. As benchmark currencies we have taken the pound, the yen, and the dollar. From Table 5.6, we can conclude that the component structures of exchange rate returns and hedged real estate returns differ markedly. Although the correlations of the principal components with the currency returns strongly depend on the choice of the numeraire currency, one conclusion can be drawn: The component structure of currency returns does not follow clear continental boundaries. The question is now to what extent the component structure of the real estate returns is influenced if we go from the hedged to 
Table 5.5: Fit of Principal Components of Real Estate Returns, Local Currency.

Overall fit of first four components (partial and cumulated)

\begin{tabular}{llllll}
\hline Component & 1 & 2 & 3 & 4 & cumulated \\
\hline Variance & 0.0525 & 0.0160 & 0.0111 & 0.0063 & \\
Fit $(\%)$ & 51 & 16 & 11 & 6 & 84 \\
\hline
\end{tabular}

Percentage of total variance of national real estate return index explained by first four components.

\begin{tabular}{lrrrrrrrrrrrrr}
\hline & fr & sp & sd & sw & uk & au & hk & jp & ml & sg & cn & us \\
\hline 1 & 9 & 50 & 6 & 3 & $\mathbf{5 9}$ & $\mathbf{5 3}$ & $\mathbf{6 5}$ & 2 & 62 & $\mathbf{8 1}$ & 50 & $\mathbf{6 0}$ \\
2 & 5 & 1 & 4 & 1 & 0 & 0 & 0 & 91 & 7 & 2 & 7 & 5 \\
3 & 2 & 10 & 1 & 3 & 0 & $\mathbf{2 1}$ & $\mathbf{2 0}$ & 5 & $\mathbf{1 8}$ & $\mathbf{1 1}$ & 0 & 0 \\
4 & 4 & $\mathbf{3 5}$ & 4 & 1 & 1 & 2 & 9 & 0 & 0 & 0 & 5 & 3 \\
$1-4$ & 20 & 96 & 15 & 8 & 60 & 76 & 94 & 98 & 87 & 94 & 62 & 68 \\
\hline
\end{tabular}

Notes: Entries show 100 times the squared correlation of component $i$ with each of the property returns, and the cumulated fit of the first four components.

Numbers in bold print are larger than the fit from the principal components analysis; fr = France, $\mathrm{sp}=$ Spain, $\mathrm{sd}=$ Sweden, $\mathrm{sw}=$ Switzerland, uk $=$ United Kingdom; aw $=$ Australia, $h \mathbf{k}=$ Hong Kong, jp $=$ Japan, $\mathrm{ml}=$ Malaysia, $\mathrm{sg}=$ Singapore, $\mathrm{cn}=$ Canada, $\mathrm{us}=$ United States.

the unhedged situation. In other words: does the divergent component structure of the currency returns alter the inferences from the principal components analysis or does it not?

To answer that question and to get a further understanding of the component structure of international real estate returns, we analyze the real estate returns expressed in the three different numeraire currencies, pound, yen, and dollar ${ }^{7}$. The results are shown in Table 5.7. Again, the upper part of the table gives the variance and average fit of the first four components. Together, they explain $77 \%$ of the total variance. A first obvious conclusion is that the difference between the unhedged and the hedged situation is small. The fit of the first four

7 We also have results for the international real estate returns expressed in the other nine currencies, but we have not presented those here. The results are similar to those for the pound, the yen, and the dollar. 
Table 5.6: Fit of Principal Components of Exchange Rate Returns.

Overall fit of first four components (partial and cumulated)

\begin{tabular}{llllll}
\hline Component & 1 & 2 & 3 & 4 & cumulated \\
\hline Variance & 0.0264 & 0.0117 & 0.0042 & 0.0036 & \\
Fit (\%) & 52 & 23 & 8 & 7 & 90 \\
\hline
\end{tabular}

Percentage of total variance of national real estate return index explained by first four components.

a. United Kingdom is benchmark country

\begin{tabular}{lrrrrrrrrrrrr}
\hline & fr & sp & sd & sw & uk & au & hk & jp & ml & sg & cn & us \\
\hline 1 & 0 & 0 & 7 & 11 & 62 & 53 & 2 & 44 & 43 & $\mathbf{5 9}$ & $\mathbf{5 3}$ \\
2 & 10 & 10 & 16 & 10 & 17 & 25 & 6 & $\mathbf{2 7}$ & $\mathbf{2 3}$ & 15 & $\mathbf{2 4}$ \\
3 & 6 & 5 & $\mathbf{1 3}$ & $\mathbf{1 0}$ & 6 & $\mathbf{8}$ & $\mathbf{8 2}$ & 5 & $\mathbf{1 0}$ & 5 & 7 \\
4 & $\mathbf{7 9}$ & $\mathbf{6 6}$ & $\mathbf{6 0}$ & $\mathbf{5 9}$ & 14 & $\mathbf{1 4}$ & $\mathbf{1 0}$ & $\mathbf{1 9}$ & $\mathbf{1 5}$ & $\mathbf{1 5}$ & $\mathbf{1 4}$ \\
1.4 & 95 & 81 & 96 & 90 & 89 & 100 & 100 & 95 & 91 & 94 & 98 \\
\hline
\end{tabular}

b. Japan is benchmark country

\begin{tabular}{lrrrrrrrrrrrr}
\hline \multicolumn{1}{r}{} & $\mathrm{fr}$ & $\mathrm{sp}$ & $\mathrm{sd}$ & $\mathrm{sw}$ & uk & au & hk & jp & ml & sg & cn & us \\
\hline 1 & 1 & $\mathbf{3}$ & 18 & 3 & 2 & $\mathbf{6 3}$ & $\mathbf{6 9}$ & & $\mathbf{5 4}$ & $\mathbf{5 7}$ & $\mathbf{6 8}$ & $\mathbf{6 9}$ \\
2 & 0 & 0 & 0 & 0 & 6 & $\mathbf{2 6}$ & 9 & & 7 & 6 & 3 & 9 \\
3 & $\mathbf{6 8}$ & $\mathbf{7 2}$ & $\mathbf{6 9}$ & $\mathbf{5 8}$ & $\mathbf{8 2}$ & $\mathbf{9}$ & $\mathbf{1 9}$ & $\mathbf{3 3}$ & $\mathbf{2 6}$ & $\mathbf{2 3}$ & $\mathbf{1 8}$ \\
4 & $\mathbf{2 6}$ & $\mathbf{1 4}$ & $\mathbf{9}$ & $\mathbf{2 1}$ & $\mathbf{1 0}$ & 2 & 1 & & 2 & 1 & 2 & 2 \\
$1-4$ & 95 & 89 & 96 & 82 & 100 & 100 & 98 & & 96 & 90 & 96 & 98 \\
\hline
\end{tabular}

c. United States is benchmark country

\begin{tabular}{lrrrrrrrrrrrr}
\hline & fr & sp & sd & sw & uk & au & hk & jp & ml & sg & en & us \\
\hline 1 & $\mathbf{7 7}$ & $\mathbf{7 4}$ & $\mathbf{7 6}$ & $\mathbf{8 4}$ & $\mathbf{5 3}$ & 5 & 2 & $\mathbf{6 9}$ & 29 & 22 & 0 \\
2 & 10 & 12 & $\mathbf{1 6}$ & $\mathbf{7}$ & $\mathbf{2 4}$ & $\mathbf{9 2}$ & 0 & 9 & 3 & 6 & 11 \\
3 & 2 & 2 & 1 & 0 & 7 & 0 & 0 & $\mathbf{1 8}$ & 6 & 0 & 3 \\
4 & 6 & 2 & 1 & 2 & $\mathbf{1 4}$ & 1 & 0 & 2 & 0 & 2 & 0 \\
$1-4$ & 95 & 90 & 94 & 93 & 98 & 97 & 2 & 98 & 80 & 30 & 14 \\
\hline
\end{tabular}

Notes: Entries show 100 times the squared correlation of component $i$ with each of the exchange rate returns, and the cumulated fit of the first four components. Numbers in bold print are larger than the fit from the principal components analysis; $\mathrm{fr}=$ France, $\mathrm{sp}=\mathrm{Spain}, \mathrm{sd}=$ Sweden, $\mathrm{sw}$ $=$ Switzerland, uk $=$ United Kingdom, ${ }_{\text {au }}=$ Australia, hk = Hong Kong, jp $=$ Japan, $\mathrm{ml}=$ Malaysia, $\mathrm{sg}=$ Singapore, $\mathrm{cn}=$ Canada, us = United States. 
Table 5.7: Fit of Principal Components of Real Estate Returns, Common Benchmark Currencies.

Overall fit of first four components (partial and cumulated)

\begin{tabular}{llllll}
\hline Component & 1 & 2 & 3 & 4 & cumulated \\
\hline Variance & 0.0294 & 0.0132 & 0.0113 & 0.0072 & \\
Fit $(\%)$ & 37 & 17 & 14 & 9 & 77 \\
\hline
\end{tabular}

Percentage of total variance of national real estate return index explained by first four components.

a. United Kingdom is benchmark country

\begin{tabular}{rrrrrrrrrrrrrr}
\hline & glp & fr & sp & sd & sw & uk & au & hk & jp & ml & sg & cn & us \\
\hline 1 & $\mathbf{4 8}$ & 0 & 20 & 2 & 1 & 31 & 35 & $\mathbf{4 7}$ & 15 & $\mathbf{6 9}$ & $\mathbf{7 6}$ & 25 & 28 \\
2 & 7 & 2 & 1 & 0 & 5 & 2 & 3 & 1 & $\mathbf{5 1}$ & 13 & $\mathbf{1 7}$ & 8 & 4 \\
3 & $\mathbf{2 1}$ & 1 & $\mathbf{2 2}$ & 1 & 0 & 11 & $\mathbf{3 4}$ & $\mathbf{3 9}$ & $\mathbf{2 9}$ & 2 & 1 & 9 & 6 \\
4 & 2 & $\mathbf{1 8}$ & $\mathbf{4 7}$ & 5 & $\mathbf{1 6}$ & 0 & 4 & 1 & 0 & 0 & 1 & 5 & 1 \\
$1-4$ & $\mathbf{7 8}$ & $\mathbf{2 1}$ & 90 & 8 & $\mathbf{2 2}$ & $\mathbf{4 4}$ & $\mathbf{7 6}$ & $\mathbf{8 8}$ & 95 & 84 & 95 & 47 & 39 \\
\hline
\end{tabular}

b. Japan is benchmark country

\begin{tabular}{rrrrrrrrrrrrrr}
\hline & glp & fr & sp & sd & sw & uk & au & hk & jp & ml & sg & cn & us \\
\hline 1 & $\mathbf{5 8}$ & 3 & 25 & 4 & 1 & 35 & $\mathbf{3 9}$ & $\mathbf{5 0}$ & $\mathbf{1 3}$ & $\mathbf{7 1}$ & $\mathbf{7 9}$ & 30 & $\mathbf{3 7}$ \\
2 & 3 & 4 & 3 & 0 & 10 & 1 & 4 & 2 & $\mathbf{4 8}$ & 11 & 15 & 5 & 2 \\
3 & $\mathbf{1 7}$ & 0 & $\mathbf{1 8}$ & 1 & 2 & 9 & $\mathbf{2 9}$ & $\mathbf{3 5}$ & $\mathbf{3 3}$ & 2 & 1 & 8 & 4 \\
4 & 0 & 6 & $\mathbf{4 2}$ & $\mathbf{1 4}$ & 1 & 1 & 6 & 2 & 0 & 0 & 0 & 1 & 0 \\
$1-4$ & $\mathbf{7 8}$ & 13 & $\mathbf{8 8}$ & 19 & 14 & 46 & $\mathbf{7 8}$ & 89 & 94 & 84 & 95 & 44 & 43 \\
\hline
\end{tabular}

c. United States is benchmark country

\begin{tabular}{rrrrrrrrrrrrrr}
\hline & glp & fr & sp & sd & sw & uk & au & hk & jp & ml & sg & cn & us \\
\hline 1 & 30 & 2 & 12 & 0 & 9 & 13 & 26 & $\mathbf{3 8}$ & 22 & $\mathbf{6 3}$ & $\mathbf{7 0}$ & 14 & 23 \\
2 & 8 & 1 & 1 & 0 & 3 & 2 & 3 & 1 & $\mathbf{4 6}$ & 15 & $\mathbf{2 0}$ & 9 & 6 \\
3 & $\mathbf{3 0}$ & 3 & $\mathbf{2 6}$ & 1 & 0 & $\mathbf{1 4}$ & $\mathbf{4 1}$ & $\mathbf{4 6}$ & $\mathbf{2 7}$ & 2 & 2 & 12 & 12 \\
4 & 4 & $\mathbf{1 7}$ & $\mathbf{5 1}$ & 6 & $\mathbf{1 2}$ & 0 & 4 & 1 & 0 & 0 & 1 & 6 & 3 \\
$1-4$ & 72 & 23 & 90 & 7 & 24 & 29 & 74 & 86 & 95 & 80 & 93 & 41 & 44 \\
\hline
\end{tabular}

Notes:

Entries show 100 times the squared correlation of component $i$ with each of the property returns experessed in a common benchmark currency, and the cumulated fit of the first four components. Numbers in bold print are larger than the fit from the principal components analysis; glp = global property share index, fr $=$ France, $\mathrm{sp}=$ Spain, $\mathrm{sd}=$ Sweden, $\mathrm{sw}=$ Switzerland, $\mathrm{uk}=$ United Kingdom, au $=$ Australia, $\mathrm{hk}_{\mathrm{k}}=$ Hong Kong $\mathrm{j}_{\mathrm{jp}}=$ Japan, $\mathrm{ml}$ $=$ Malaysia, $\mathrm{sg}=$ Singapore, $\mathrm{cn}=$ Canada, us $=$ United States. 
components, both individual and combined, is not altered to a great extent if we go from returns in locall currency to returns in some numeraire currency. The divergent component structure of the currency returns appears not to play an important role in the component structure of unhedged real estate returns. Therefore, we can conclude that the component structure of the international real estate returns is largely invariant to the decision to either hedge or not hedge the portfolio. This can probably be explained by the fact that the volatilities of the property indices are far higher than those of the exchange rates. This finding is confirmed if we look at panels a through $\mathrm{c}$ of Table 5.7. The correlations of the property index returns with the principal components are not significantly influenced if we go from one numeraire to another.

In Table 5.7, we have also included results for a global property share index, which is the equally weighted average of the returns indices for the twelve individual countries. Since the returns of this index have to be expressed in some numeraire currency, we could not introduce it before. From Table 5.7, an obvious conclusion is that the first and the third principal components are international, since the global property share index is chiefly explained by these components. This first component is also highly correlated to the Far East countries, which confirms our inference from Table 5.5. The third component also mainly correlates with the Far East, although it explains the real estate returns of some European countries as well.

As was the case when we used real estate returns expressed in local currency, the second component stands out as a Japanese phenomenon. In Figure 5.1 we have plotted Japanese real estate returns expressed in United States dollars, versus the second principal component. The similarity between the two is striking and further illustrates the uniqueness of the Japanese real estate market. The fourth component in Table 5.7 mainly determines continental European real estate returns. Especially Spain is influenced by this component. Based on the results in Tables 5.5 and 5.7, we can roughly identify the following groups of countries:

1. Australia, Hong Kong, Malaysia, Singapore (and maybe the United Kingdom)

2. Japan

3. France, Spain, Sweden, Switzerland (and maybe the United Kingdom)

4. Canada, United States. 
Figure 5.1

Japanese Property Share Returns and the Second Component

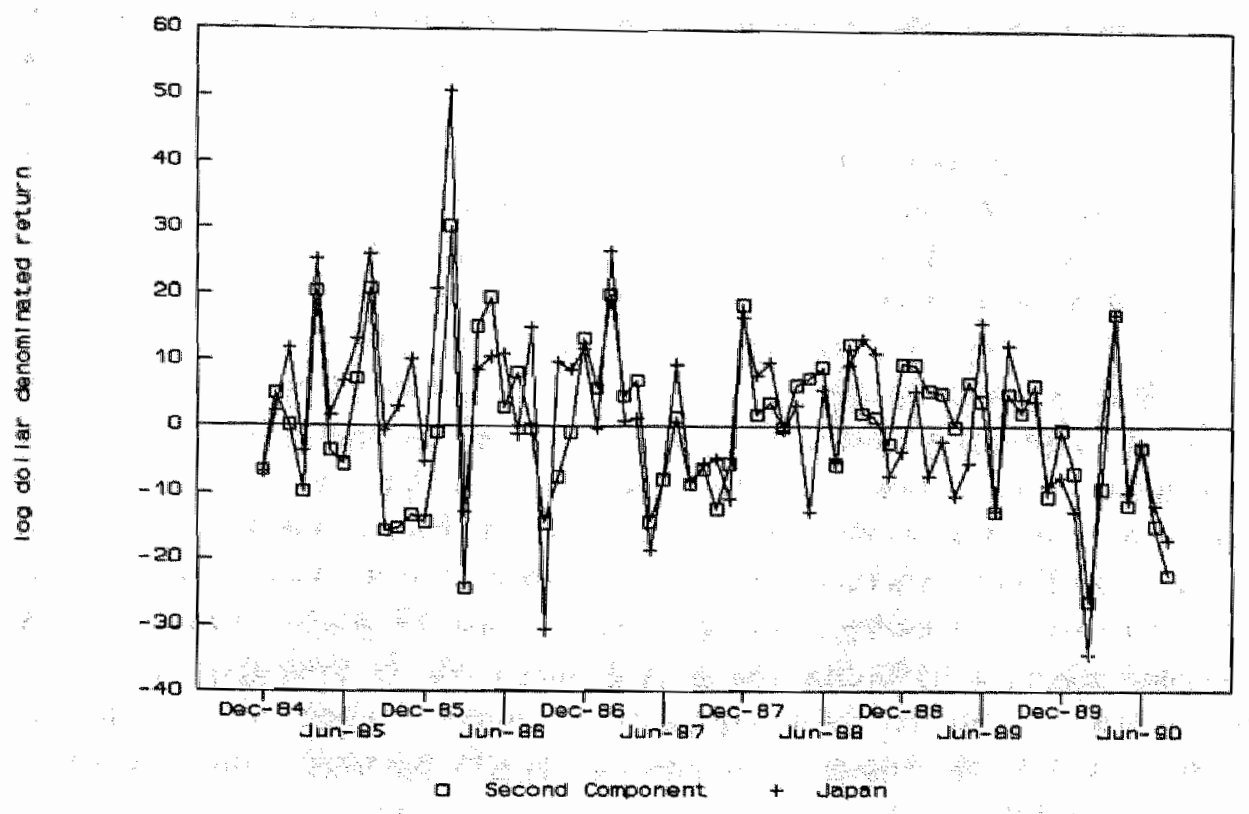

These groups largely follow the continental boundaries we expected to find in the international real estate returns. The notable exceptions are Japan and the United Kingdom. Japan clearly stands on its own, and its real estate markets do not bear a significant relationship to any of the continental factors we identify. The United Kingdom, on the other hand, does not stand on its own, but does not clearly belong to any group either. Both the real estate markets of Far Eastern countries and of continental Europe show common movements with the British market. This agrees with Section 5.2, in which we found that for both Japan and the United Kingdom trade flows with the other countries in their respective continents did not predominate. The North American countries' real estate markets are not strongly explained by any of the four components, but show a close similarity in their correlation structure to these components, independent of the chosen numeraire currency. 


\subsection{Conclusions}

In this chapter, we have investigated the existence of a continental factor driving real estate returns. First, we have examined various institutional and intuitive reasons why such a factor should exist. We have found that restrictions on trade and capital flows are lower between countries belonging to one continent than between countries in different continents. We have also seen that trade flows are stronger within continents than between them. The second part of our analysis is of a more formal nature. We have developed and used the generalized numeraire free principal components methodology to extract the continental real estate factors. Our results clearly indicate that such factors exist. Especially within the Far East and North America, reall estate returns show common movements and appear to be determined by the same factor. The existence of continental real estate factors implies that optimal international diversification in real estate portfolios can't be accomplished by investing in only one continent. For efficient international diversification, an intercontinental approach is required. Another interesting finding of this chapter is that the component structure of international real estate returns is largely independent of the decision whether to hedge against currency risk or not. Exchange rate returns appear not to play an important role in the component structure of international real estate returns, since currency risk is far lower than real estate risk. 


\section{Are Correlations between International Property Share Returns Stable?}

International diversification reduces the risk of investment portfolios since asset returns in different countries are not perfectly correlated. The extent of this risk reduction has been investigated in numerous studies, of which Grubel (1968), Levy and Sarnat (1970), Grubel and Fadner (1971), Lessard (1973), Ripley (1973), and Solnik (1974b) were the among the first. For real estate, this subject has received less attention, as we noted in Chapter 1. Still, several attempts have been made to examine the risk reduction possiblities of international diversification of the real estate portfolio, and even to determine the optimal international allocation of real estate investments by using portfolio models. Sweeney (1989) calculates the correlations between office rent indices in major cities across the world. Since these are often negative, she concludes that the diversification potential of international real estate investments is substantial. She also determines the composition of efficiently diversified international real estate portfolios, using a Markowitz (1952, 1959) portfolio model. As inputs for the model, she uses the realized covariance matrix based on the rent indices. The compositions of the resulting efficient portfolios are somewhat counterintuitive, since New York and Frankfurt have no place in these portfolios, and Tokyo, Hong Kong, Madrid and Brussels hardly.

Giliberto (1990a), and Giliberto and Testa (1990) use the returns of property shares to demonstrate the risk reduction possibilities of international real estate diversification, and to calculate efficient portfolios. Again, the potential for risk reduction is found to be substantial, and the composition of the efficient portfolios counterintuitive. This indicates the limitations of the Markowitz approach when applied to the problem of international real estate diversification. Gordon (1992) bases his calculations of efficient frontiers on appraisal-based real estate returns. He only looks at investments in the United Kingdom and the United States, and again concludes that portfolio risk is reduced when investing internationally.

The efficient international portfolios generated by Markowitz portfolio models 
critically depend on the covariance structure of the international returns. To allocate international investments in an efficient way, investors have to make ex-ante estimates of this covariance structure. Usually, this is done by using the realized covariance figures. This, however, is only justified if the international covariance structure of asset returns is stable in time. If this is not the case, then this covariance structure describes only the past, and not, as would be more interesting, the future.

Thus, the stability of the variances and of the correlations of international property share returns are essential to the applicability of portfolio models to the problem of optimal international real estate allocation. Sofar, researchers of international real estate investments were not able to test for this stability, due to lack of real estate returns data with a long enough history. We have monthly property share returns data over the past 20 years, which allows us to test the stability of the correlation matrix in a reliable way.

In Chapter 4, we have seen that some events simultaneously influence the returns on property shares in all countries. An example was the October 1987 stock market crash. In the same chapter, we have seen that property share returns are not only linked with the stockmarkets, but also with the real estate markets. In real estate markets, return-influencing events tend to be of a more local nature. In Chapters 2 and 3 , we have shown that regional real estate markets are influenced by dynamics in regional economies. This causes nonsimultaneous developments in different real estate markets. Examples of this are easy to find: In parts of the United States, like Texas, real estate prices and rents went through a crisis in the late eighties, while the Texas real estate market is currently flourishing. On the other hand, the Japanese market is presently in the doldrums, while continental European countries like Germany and Belgium hardly experience a crisis in their markets at all. National real estate markets are influenced by national economic factors, which do not influence other real estate markets. If these national economic factors act nonsynchronous with economic factors in other countries, and this is probably the case, then unstable international covariance structures of property share returns would be likely.

In this last empirical chapter we investigate the stability of the international correlation and covariance structure of property share returns. The chapter proceeds as follows. In Section 6.1. we describe the international property share 
data we use. Section 6.2 explores the existing research concerning stability of the variance and covariance in international asset returns. Also in this section, we present some tests of this stability, and their results. In Section 6.3 we discuss some of the consequences of the results of our analysis. Section 6.4 concludes the chapter.

\subsection{Data}

We use the national property share indices from the Datastream Global Indices. For nine countries, these indices have sufficient length for our purposes. The countries are Belgium, France, Italy, the United Kingdom, Australia, Japan, Singapore, Canada, and the United States. For these countries, the time series of the property share returns index runs from 1973 through 1993. This time period is long enough to be able to divide it into subperiods and to make reliable inferences regarding the stability of the covariance structure. The time span of the data covers the emergence of the European Monetary System and its recent demise, and, for most countries included, at least one crisis in their real estate markets. Furthermore, the data covers a period characterized by the progressive removal of barriers to international capital flows and growing international economic and financial integration. This could imply an increase in the international correlation of asset returns ${ }^{1}$.

Sample statistics in local currency and market values in United States dollars of the Datastream property share indices are included in Table 6.1. The annualized mean returns range from $5.04 \%$ for Canada to $16.56 \%$ for Australia. As one can also see from this table, property shares have been quite risky investments in the sample period. The standard deviations of monthly returns are between $6 \%$ and $10 \%$ for all countries, with the notable exceptions of Canada (11.00\%) and Singapore $(13.18 \%)$.

Table 6.2 gives the full sample correlation matrix of the Datastream property

1 We could not use the Salomon Russell Global Property Share Index, which we used in Chapters 4 and 5 . This dataset includes monthly data from January 1985 through September 1990 . Since it only reports 69 observations, and covers a relatively stable time period for international real estate markets, using this database to determine the stability of the correlation matrix would not yield reliable results. 
Table 6.1 Datastream Property Share Indices. Annualized Monthly Returns, Local Currency, February 1973 - May 1993. Market Values at December 1992.

\begin{tabular}{lrrrrr} 
& $\begin{array}{c}\text { Mean } \\
\text { (Annualized) }\end{array}$ & Std & Min & Max & $\begin{array}{r}\text { Value } \\
\text { (US \$) }\end{array}$ \\
\hline Belgium & 10.44 & 6.45 & -22.78 & 25.13 & 263 \\
France & 12.48 & 6.85 & -26.92 & 28.58 & 2,664 \\
Italy & 11.40 & 8.53 & -21.55 & 48.54 & 931 \\
United Kingdom & 11.88 & 8.92 & -42.99 & 39.00 & 10,294 \\
Australia & 16.56 & 9.49 & -60.38 & 31.18 & 2,722 \\
Japan & 6.48 & 8.17 & -27.93 & 44.77 & 30,831 \\
Singapore & 7.68 & 13.18 & -67.55 & 55.40 & 4,140 \\
Canada & 5.04 & 11.00 & -44.31 & 91.83 & 1,337 \\
United States & 6.36 & 6.64 & -40.75 & 19.01 & 5,093 \\
\hline
\end{tabular}

Note: $\quad$ For Canada, the time period is February $1976-$ May 1993.

Table 6.2 Correlation Matrix Property Share Returns. Full Sample: February 1973 - May 1993, Monthly Returns, Local Currency.

\begin{tabular}{lllllllll} 
& bg & fr & it & uk & au & jp & sg & cn \\
\hline fr & 0.26 & & & & & & & \\
it & 0.23 & 0.20 & & & & & & \\
uk & 0.15 & 0.22 & 0.18 & & & & & \\
aui & 0.16 & 0.26 & 0.23 & 0.32 & & & & \\
jp & 0.10 & 0.30 & 0.07 & 0.16 & 0.17 & & & \\
sg & 0.11 & 0.18 & 0.19 & 0.38 & 0.44 & 0.18 & & \\
en & 0.13 & 0.15 & 0.11 & 0.23 & 0.20 & 0.11 & 0.23 & \\
us & 0.14 & 0.33 & 0.10 & 0.22 & 0.36 & 0.20 & 0.37 & 0.13 \\
\hline
\end{tabular}

Notes: Correlations for Canada are calculated for the period February 1976 - May 1993.

bg $=$ Belgium, $\mathrm{fr}=$ France, $\mathrm{it}=$ Italy, $\mathrm{uk}=$ United Kingdom, au $=$ Australia, $\mathrm{jp}=$ Japan, $\mathrm{sg}=$ Singapore, $\mathrm{cn}=$ Canada, us $=$ United States. 
share returns. The diversification potential of international property share investments has been substantial in our sample period. Although all correlations are positive, and differ significantly from zero, they are not high, ranging from 0.07 between Italy and Japan to 0.44 between Singapore and Australia. The question is, were these correlations constant?

\subsection{The Stability of Correlations, Variances and Covariances}

The literature regarding the stability of the variance-covariance structure of international asset returns is not vast. Most papers sofar published investigate international common stock returns. Kaplanis (1988) investigates for 10 countries the stability of the international correlation and covariance matrices of monthly stock market returns for the period 1967 through 1982. She compares matrices estimated over 4 equal subperiods using tests developed by Jennrich (1970) and Box (1949) $)^{2}$. The null hypothesis that the correlation matrix is stationary over any two time periods - adjacent or not - could not be rejected at the $85 \%$ confidence level. On the other hand, the null hypothesis of a stationary covariance matrix could be rejected at the $95 \%$ confidence level for most subperiods compared. Kaplanis also found that the test statistics for consecutive periods tend to be lower than for non-consecutive periods. This indicates a gradual change of the true covariance matrix. This, in its turn, implies that using realized covariance matrices as inputs for portfolio models only yields reliable results for the short term optimal portfolio composition.

Longin and Solnik (1993) also test the stationarity of correlation and covariance matrices with the Jennrich test, albeit for a longer time period: 1960 through 1990. Subsequently, they investigate the stability of the conditional correlation using Generalized Autoregressive Conditional Heteroskedasticity (GARCH) models. They find that the correlation matrix is stable between some time periods, and unstable between others. The covariance matrix, on the other hand, was found to be unstable for all time periods.

We perform tests on both the covariance matrix and the correlation matrix of

${ }^{2}$ The Jennrich test for stability of the covariance matrix is asymptotically equivalent to the Box test. For small samples, the two statistics could give different outcomes, but Kaplanis (1988) finds equivalent results for subsample lengths of 46 months. 
property share returns, using the Jennrich test ${ }^{3}$. We present the results of the analysis of returns expressed in local currency, and in nominal terms. These are the returns earned by an investor who is fully hedged against currency risk, but not hedged against inflation risk. We also did stability tests when the covariance matrix was expressed in United States dollars, and/or was based on real returns, but the results were very similar and are therefore not presented here.

Except for the Canadian time series of property share returns we divide all time series into four equal subperiods of 61 months. This is long enough to yield reliable results (See Kaplanis, 1988). The four subperiods are February 1973 through February 1978, March 1978 through March 1983, April 1983 through April 1988, and May 1988 through May 1993. The Canadian time series is divided into three subperiods beginning and ending simultaneously with the second through fourth subperiod of the other time series. In Tables 6.3 and 6.4 we present results of the Jennrich test for stability of the correlation matrix and the covariance matrix, respectively. When comparing the first period matrix to other matrices, we exclude the Canadian correlations.

We first test the null hypothesis that the correlation matrix is stable. The Jennrich $\chi^{2}$ statistic in Table 6.3 indicates that stability of the correlation matrix is not rejected at conventional siginificance levels, except when comparing the first and second periods to the third period. The covariance matrix is unstable regardless of the time periods we compare (Table 6.4). This implies that the variance of international asset returns is less stable than their correlation. This, in its turn, agrees with the findings of Kaplanis and Longin and Solnik and with

3 The Jennrich $x^{2}$ test statistic for stability of the correlation matrix has $p(p-1) / 2$ degrees of freedom, with $p$ the dimension of the correlation maltrix. The statistic is

$$
\chi^{2}=\frac{1}{2} \operatorname{tr}\left(Z^{2}\right)-\operatorname{diag}^{\prime}(Z) s^{-1} \operatorname{diag}(Z)
$$

Here, $Z=c^{1 / 2} R^{-1}\left(R_{1}-R_{2}\right)$, in which $R=\left(n_{1} R_{1}+n_{2} R_{2}\right) /\left(n_{1}+n_{2}\right)$ and $c=n_{1} n_{2} /\left(n_{1}+n_{2}\right)$, with $R_{1}$ and $R_{2}$ the correlation matrices to be compared, and $n_{1}$ and $n_{2}$ the number of observations on which they are based. Furthermore, $S=\left(\delta_{i j}+r_{i j} j^{j}\right)$, with $\delta_{i j}$ the Kronecker delta, $r_{i j}$ the elements of $R$, and $r^{i j}$ the elements of $R^{-1}$. To get the Jennrich $\chi^{2}$ statistic for stability of the covariance matrix, the second term of the equation is omitted. In that case, the statistic has $p(p+1) / 2$ degrees of freedom. 
Table 6.3 Stability of the Correlation Matrix. Results of the Jennich Test.

Periods compared

\begin{tabular}{|c|c|c|c|}
\hline \multicolumn{2}{|c|}{ Periods compared } & \multirow[b]{2}{*}{$\begin{array}{c}\text { Jennrich } \\
\chi^{2} \text { statistic }\end{array}$} & \multirow[b]{2}{*}{$\mathrm{p}$-value } \\
\hline I & III & & \\
\hline Feb 73/Feb 78 & Mar $78 /$ Mar 83 & 33.72 & 0.21 \\
\hline Mar 78/Mar 83 & Apr 83/Apr 88 & 56.18 & 0.02 \\
\hline Apr $83 /$ Apr 88 & May $88 /$ May 93 & 40.72 & 0.27 \\
\hline Feb $73 /$ Feb 78 & Apr 83/Apr 88 & 46.72 & 0.01 \\
\hline Mar 78/Mar 83 & May $88 /$ May 93 & 44.84 & 0.15 \\
\hline Feb 73/Feb 78 & May $88 /$ May 93 & 33.21 & 0.23 \\
\hline
\end{tabular}

Table 6.4 Stability of the Covariance Matrix. Results of the Jennrich Test.

Periods compared

\begin{tabular}{cccc} 
I & \multicolumn{1}{c}{ II } & $\begin{array}{c}\text { Jennrich } \\
\chi^{2} \text { statistic }\end{array}$ & p-value \\
\hline Feb 73/Feb 78 & Mar 78/Mar 83 & 121.95 & 0.00 \\
Mar 78/Mar 83 & Apr 83/Apr 88 & 124.58 & 0.00 \\
Apr 83/Apr 88 & May 88/May 93 & 83.37 & 0.00 \\
& & & \\
Feb 73/Feb 78 & Apr 83/Apr 88 & 125.05 & 0.00 \\
Mar 78/Mar 83 & May 88/May 93 & 115.33 & 0.00 \\
& & & 0.00 \\
\hline
\end{tabular}


Table 6.5 Stability of the Variances. Results of the Jennrich Test.

\begin{tabular}{|c|c|c|c|c|c|c|}
\hline \multirow[b]{2}{*}{$\begin{array}{l}\text { Periods Compared } \\
\text { Country }\end{array}$} & \multicolumn{6}{|c|}{ Sennrich $\chi^{2}$ Statistics } \\
\hline & $a$ to $b$ & $b$ to $c$ & $c$ to d & a to $c$ & $\mathrm{~b}$ to $\mathrm{d}$ & a to $d$ \\
\hline Belgium & 10.41 & 0.03 & 0.35 & 9.55 & 0.18 & 12.79 \\
\hline France & 0.84 & 11.89 & 7.81 & 17.23 & 0.60 & 2.80 \\
\hline Italy & 8.84 & 8.79 & 8.67 & 0.00 & 26.73 & 8.63 \\
\hline United Kingdom & 27.58 & 0.37 & 0.75 & 24.01 & 0.07 & 29.06 \\
\hline Australia & 20.15 & 14.05 & 20.30 & 1.05 & 1.10 & 26.42 \\
\hline Japan & 13.17 & 32.37 & 0.49 & 9.70 & 28.48 & 6.25 \\
\hline Singapore & 5.82 & 0.19 & 17.93 & 4.06 & 15.36 & 30.06 \\
\hline Canada & - & 15.13 & 2.13 & - & 7.18 & - \\
\hline United States & 12.26 & 2.06 & 0.42 & 5.07 & 0.64 & 8.03 \\
\hline
\end{tabular}

Notes: The critical value of the $\chi^{2}$ statistic with 1 degree of freedom at the 95 per cent significance level is 3.84 .

Period $\mathrm{a}=$ February 1973 - February 1978, Period b = March 1978 March 1983, Period $\mathrm{c}=$ April 1983 - April 1988, Period d $=$ May 1988 May 1993.

intuition. After all, correlations may remain constant while variances change, if variabilities of international real estate returns change simultaneously and equivalently. The opposite, changing correlations with constant variances, is less likely. The $\mathrm{p}$-values for the Jennrich test on the covariance matrix are lower than those of Kaplanis and Longin and Solnik. This can be explained by the more local nature of property markets relative to the stock markets.

The question remains whether the observed instability of the covariance matrix is structural or merely caused by a uniform change in of the individual variances and covariances. Therefore, we examine the stationarity of the variances of 
national property share returns, also using the Jennrich $\chi^{2}$ statistic ${ }^{4}$. The results are presented in Table 6.5. For all countries, variances are nonstationary between most of the subperiods.

\subsection{Consequences of Instability}

Kaplanis further compares alternative ways to forecast the correlation and covariance structures of international asset returns. Unfortunately, the forecasting techniques she tests hardly perform better than the simple historic model, which is to use the terms of the matrix of the previous subperiod. Our correlations and covariances are even less stable than those found by Kaplanis, which leads one to expect that predictions regarding them are even harder to make.

The inability to forecast the international covariance matrix of real estate returns casts further doubt on the use of portfolio models to generate the optimal international real estate portfolio allocation. Even if these models are adjusted for the possibilities of time-varying covariances, they do not yield reliable results. Engel and Rodrigues $(1989,134)$, test the international CAPM with time-varying covariances and conclude that "the model does not get a shred of support".

\subsection{Conclusions}

In this chapter, we have investigated whether correlations, variances and covariances between international property share returns are stable. Our findings indicate that correlations, although not always stable, are more stable than variances and covariances. Nevertheless, the instability of the covariances limits the use of standard portfolio models to determine the optimal allocation of international real estate investments. To that end, a more successful strategy is to estimate market values of real estate in different countries. Corrected for the effects of segmentation between national capital markets, these values can then give an indication of the composition of the optimal international real estate portfolio.

${ }^{4} R_{1}$ and $R_{2}$ are now 1 by 1 matrices of variances of national property share returns in subperiods 1 and 2 . In this case, the Jennrich $\chi^{2}$ test statistic has 1 degree of freedom. 


\title{
PART THREE
}

\author{
Conclusions
}


3 


\section{Chapter 7}

\section{Summary and Suggestions for Further Research}

This study is concerned with various issues concerning the diversification of real estate portfolios. In the first chapter, we have argued that the art of real estate portfolio diversification is the main added benefit of an investment expert over the uninitiated. This is a direct consequence of the applicability of the financial economics paradigm to real estate finance. In this last chapter, we give an overview of the key findings of this study. Besides the scientific relevance of these findings, we focus on their practical implications. The second goal of this chapter is to give suggestions for a future research agenda in the field of real estate diversification, both with an international and with a Dutch perspective.

\subsection{Summary}

For empirical research in real estate investments, the foremost problem is that real estate returns are not directly observable. This is due to the heterogeneity of property and the lack of a central market place where prices are made public. This study is not only empirical in nature, it is also international. This implies that the data problems are aggravated, and therefore an important contribution of this dissertation is the exploration of hitherto unexamined datasets.

This holds especially for Part One, in which we focus on the question of real estate diversification by geographic region. More specifically, we investigate economic, rather than regional, diversification of the real estate portfolio. In this approach we analyze the basic economic composition of regions to determine efficient diversification strategies. To classify regions, we use employment shares in economic sectors, thus making a demand side connection to the real estate market. This connection is not formally tested in Chapter 2, but the intuition behind this approach is appealing. The idea is that regions which share basic economic characteristics have correlated employment. Therefore, real estate returns among these regions will also be correlated, in particular if the supply situation in these regions is similar. On the other hand, if regions do not 
share these economic characteristics, their employment figures and thus their real estate returns will probably have low or negative correlations. Risk reduction can thus be achieved by combining real estate in such regions in the portfolio.

Chapter 2 deals with economic diversification in European real estate portfolios, and distinguishes 74 different regions. It uses a modified chi-square technique to classify regions as either diverse or specialized. Our findings indicate that regions with common specializations are spread over Europe, so regionally diverse investments are not necessarily economically diverse. This suggests that real estate investors investing in Europe can't realize optimal risk reduction by regional diversification alone. To this end, it is criticall to give due weight to the economic characteristics of the regions in which is invested. On the other hand, we also find many regions to be internally diverse, which leads one to conjecture that real estate investments in such regions are less risky than in other regions. However, we do not provide empirical support for this conjecture in Chapter 2.

In Chapter 3 we develop a number of indicators of regional economic diversity and stability and we formally test their relationship with real estate risk. The assumption is that diverse and stable regional economies also have stable real estate portfolios. Again, we use regional sectoral employment shares to construct our indicators, but in this chapter we only use regional employment data from the Netherlands, which allows us to look at the problem in a very detailed way. We investigate the explanatory power of the constructed indicators of defaults in regional mortgage portfolios. To this end we use a dataset of the population of publicly insured Dutch mortgages for the period 1976 through 1990. The conclusions of this chapter are that dynamic measures of economic stability outperform static measures of economic diversity in explaining regional mortgage default rates. Currently, mortgagers insured by the Dutch public mortgage guarantee system pay no premiums for this guarantee. All risk is borne by the government. However, a discussion whether to introduce premiums is going on. Our results imply that regional economic stability should be taken into account when determining the premium for a public mortgage guarantee. The main finding of the chapter is that the demand side relationship between the real estate market and regional employment indeed exists. In other words, the intuition behind the approach used in Chapter 2 is shown to be correct. This implies that using regional employment characteristics as a basis 
for the diversification of real estate portfolios leads to better results than regional diversification.

In Part Two of this dissertation we use property share returns data to test ideas concerned with international real estate diversification. In Chapter 4, we examine the nature of property share index returns. More specifically, we investigate to which extent these returns look like stock returns or like other known real estate return indicators, i.e. appraisal-based returns. The relationship between return indices of property shares and the stockmarket on which they trade is investigated for twelve countries using a standard market model. For all of these countries except for Switzerland, we find the stockmarket to explain the variance in the returns of property share indices to a very significant extent. This means that the diversification potential of introducing real estate in a stock portfolio is limited. For the United States, this has been shown to be the case before, but it was not clear if it would hold internationally as well. Another finding here is that there are similarities in risk and return between property share indices from countries belonging to the same continent. Stock market betas of real estate are highest in the Far East, and lowest in Europe and North America. This can probably partly be explained by differences in rent contracts between the three continents.

These findings notwithstanding, property shares also behave like real estate. In Chapter 4 we also examine the relationship between property share returns and appraisal based returns for four countries. To this end, we employ an error correction model, which leads to the conclusion that property share returns significantly predict appraisal based returns. This indicates that the use of property share returns as a proxy for real estate returns makes economic sense. This has important implications for international real estate research. Data of property share returns are available for many countries, whereas appraisal based returns data are not. This implies that international real estate research is possible for many more countries than would have been the case if research would have required appraisal based returns.

In the next chapter, Chapter 5, we continue studying the property share returns. The differences between real estate returns in different continents we found in Chapter 4 are investigated more thoroughly here. We inquire into the existence of continental factors determining real estate returns. The existence of such factors makes intuitive sense, since capital and goods and services often flow 
more freely within continents than among them. This means that simultaneous movements of both the supply and the demand of real estate in the countries in one continent can be expected. If there are indeed common international movements in real estate supply and demand, then this commonality should also be discernible in real estate returns. To study this commonality, we develop and employ a new version of principal components analysis. This method has the advantage that the components we extract are independent of the choice of the numeraire currency. This is important, since it makes our results relevant to investors from all countries.

In Chapter 5 we find clear evidence of the existence of continental factors in real estate returns: real estate markets are internationally segmented along boundaries of continents. Real estate returns in the Far East show common movements, and the same holds for Europe and North America. Japan and the United Kingdom are exceptions. Japanese real estate returns are idiosyncratic and do not show common movements with reall estate in other countries, Asian or not. On the other hand, real estate returns in the United Kingdom show common movements with both European and Far East countries' real estate returns. The implication of these findings is that intercontinental investing is required to achieve optimal international portfolio diversification. Investors trying to realize optimal risk reduction in their real estate portfolio by investing internationally cannot achieve this by only investing in one continent. The main other finding of this chapter is that the component structure of international real estate returns is largely independent of the decision whether to hedge the international real estate portfolio against currency risk or not. Currency risk does not play a very important role in the total risk of international real estate investments.

Chapter 6 , the last empirical chapter of this dissertation, looks at the variancecovariance structure of international property share returns. Portfolio models, which are used to generate efficient international asset allocations, require estimates of a variance-covariance structure of asset returns as input. Usually, the realized structure is used as a proxy. If that is the case, then the validity of the model's output critically depends on the stability of the variance-covariance strueture. In Chapter 6, we perform several tests to examine whether the structure of international property share returns is stable in time. Intuitively, one would expect this not to be the case, since property share returns are, at least partly, influenced by the real estate markets, and these, in their turn, move 
internationally in a non-synchronous way. The intuition is confirmed by our formal tests. We find covariances of international property share returns to be unstable, while correlations are stable beteen some time-periods, and unstable between others. The results cast serious doubts on the use of standard portfolio models for international real estate allocation.

\subsection{Further Research}

In this section we give suggestions for a future research agenda in real estate investments. Four aspects of this agenda are relevant to the international real estate literature, while others are specifically relevant to the Netherlands.

There is an extensive literature regarding the international diversification of stock and bond portfolios. Theoretical models like the International Capital Asset Pricing Model and the International Arbitrage Pricing Theory have been developed and exposed to the data. In contrast, international real estate portfolio diversification has not received much attention in the literature. The theoretical reasons why international diversification works for stocks and bonds also apply to real estate, but due to lack of data, empirical examination of these theories has hardly taken place. Therefore, the most vital task for a researcher in the field of international real estate portfolio diversification is the construction of databases of international real estate returns.

As a first step, it is necessary to update and expand the datasets of property share returns we use in Chapters 4 through 6 . The Salomon Brothers database only includes indices for 12 countries in the period January 1985 through September 1990. Adding data for countries from the Far East like Taiwan, Thailand, and New Zealand would be good, as would be including more European countries like Italy, Belgium, Denmark, Norway, and Austria. Another important matter is to have more observations per country index, both by giving the time series a longer history and by updating them. Partly, this is already accomplished in the Datastream dataset we use in Chapter 6. However, the indices it contains only include large stocks. Since many property companies are small stocks, this implies that a substantial amount of listed property companies is not included in the index. Based on such an expanded international dataset of property share returns, it would be possible to investigate the applicability of international asset pricing models to real estate. Less fundamentally, 
but more importantly from a practical point of view, such a dataset would allow further research in the benefits of international real estate portfolio diversification.

A second direction international real estate research should pursue is further investigation of the relationship between property share returns and appraisal based returns. In the United States, this relationship has been under extensive scrunity, but internationally, this is not the case. In Chapter 4 of this study, we have addressed this problem for four countries including the United States. The universe of countries for which this kind of research is possible should be expanded by constructing appraisal based return indices for as many countries as possible. However, this is easier said than done. In the Netherlands, for example, initiatives to this end were repeatedly undertaken, but have never led to the intended result. Nevertheless, the development of an appraisal based index is especially important for the Netherlands, since most Dutch property companies listed on the stock exchange invest predominantly abroad. The returns of their shares are therefore not useful as indicators of the returns of the Dutch real estate market. The same necessity to create an appraisal index exists for a country like Germany, where property shares are not listed on the stock exchange. For these countries, an appraisal based index would be the best indicator of real estate returns.

In the literature, the debate whether appraisal based returns are reliable indicators for real estate returns continues. Using appraisal based returns in an asset allocation model overestimates the allocation of real estate in the portfolio, due to the low variance of the returns. Therefore, it is better not to use asset allocation models to determine the optimal real estate allocation, but to estimate market values of real estate in a country. This value can then be combined with the value of other investable assets, to get the composition of the total market portfolio for the country. Optimal asset allocation within the country can then be achieved by investing pro rata in this market portfolio. Our third suggestion for an international real estate research agenda is to use the same strategy to determine the optimal country allocation of the international real estate portfolio. We have seen in Chapter 6 that the international covariance structure of property share returns is not stable. This limits the applicability of portfolio models to generate optimally diversified international real estate portfolios. By calculating the total value of real estate in many countries, however, we can get an estimate of the value and composition of the world real estate portfolio. This 
portfolio, corrected for the effects of international capital market segmentation, gives an indication of the optimal international allocation of real estate investments.

Our fourth and last suggestion regarding international real estate research concerns the use of employment data to base real estate diversification decisions upon. This approach can help these decisions in two cases; country allocation and regional allocation of real estate investments. For countries for which indices of real estate returns do not exist, employment data can be viewed as a second best indicator of real estate return behaviour, and they can be used to investigate the riskiness of real estate investments in those countries. For the regional allocation of real estate investments, the employment approach is even more useful. Real estate returns data, if available at all, is usually only available at the country level. Only in the United States, Canada, and the United Kingdom do we have regional real estate returns data, but the level of disaggregation is not very high. By contrast, regional employment data is available for many countries, and usually, the level of disaggregation is very high, often going as far as the individual metropolitan area. In this study, we use European Community employment data for 74 regions, but it is also interesting to use data for more countries than just the 12 European Community members. Also, in Chapter 3 we have concluded that changes in the economic structure of a region are linked more strongly to real estate risk than the economic structure as such. It is therefore insightful to not only analyze the economic structure, but also its dynamics: to analyze the changes of the economic structure in time.

For the Netherlands, our suggestions for future research follow three separate lines. First, as was mentioned before in this study, the construction of an appraisal based real estate returns index should be high on the list of pritorities of any real estate researcher. For the Netherlands, this is even more necessary than for other countries. A return index of Dutch property companies" shares would not give much information about Dutch real estate, since Dutch property companies mostly invest abroad. The lack of a reliable real estate returns index in the Netherlands hampers serious research and performance measurement.

The investment policy of the Dutch property companies brings us to our second suggestion regarding Dutch real estate research. Dutch property companies' investment policy differs substantially from the policy of their counterparts abroad. Except for those in the Netherlands, property companies are usually 
very regionally specialized, often investing in only one region or city. Intuitively, this makes more sense than investing all over the world. Real estate is, after all, a local business, and investors in real estate can diversify internationally by themselves, by buying the shares of locally investing property companies in different countries. This way, they buy local knowledge of real estate markets at the stock exchange. It would be interesting to investigate the best of two possible strategy for international diversification for a Dutch investor. The first strategy is to buy the shares of the internationally operating Dutch property companies, and invest globally by buying locally. The other strategy is to buy the shares of foreign property companies, which operate strictly local, and invest locally by buying globally. The results would be very relevant to Dutch institutional investors, and, may be more so, to Dutch property companies.

A third interesting field for future research in the Netherlands is mortgage risk. In Chapter 3, we have looked at mortgage default risk, using a regional point of view. Further analysis of default risk and of other risk sources of mortgages is very important, both from a practical and from a scientific point of view. A thorough investigation of the mortgage-specific risk factors, like age of the mortgage and the ratio of the mortgage value to the value of the house would be interesting, but the relationship between macro economic fundamentals and mortgage risk should also be examined. Interest rates, and their term structure, default risk premia, unemployment and national income growth are all likely to influence the risk of mortgages. Research in the determinants of mortgage risk is very important. For many banks and institutional investors, mortgages are a large part of the investment portfolio. The development of so called mortgage backed securities, bonds covered by portfolios of mortgages, has made the mortgage market even more important to investors. Mortgage risk is also an important public policy item, since the Dutch mortgage guarantee system is public; and the government wants to stimulate private home-ownership. Research into mortgage risk can lead to a better understanding of the costs and benefits of public mortgage guarantees as a catalyst to private home-ownership.

All in all, many fields in real estate finance have yet to be explored, both internationally and in the Netherlands. This dissertation, as any dissertation, merely scratches the surface of the iceberg of work still to be done. Nevertheless, in real estate finance we have come a long way since the nomad days. 


\section{References}

Adler, M. and B. Dumas, 'International Portfolio Choice and Corporation Finance:

A Synthesis', Journal of Finance, 38, 1983, 925-984.

Asabere, P.K., R.T. Kleiman and C.B. McGowan, 'The Risk-Return Attributes of International Real Estate Equities', Journal of Real Estate Research, 6, 1991, 143151.

Baldwin, J.R. and P.K. Gorecki, 'Measuring the Dynamics of Market Structure; Concentration and Mobility Statistics for the Canadian Manufacturing Sector', Annales d'Economie et de Statistique, 15/16, 1989, 315-332.

Barraclough, G. and N. Stone (eds.), The Times Atlas of World History, third edition, Times Books, London, 1989.

Benink, H.A., Financial Integration in Europe, Kluwer Academic Publishers, Dordrecht, 1993.

Black, F. and M.S. Scholes, 'The Pricing of Options and Corporate Liabilities', Journal of Political Economy, 81, 1973, 637-654.

Boughton, J.M. and G.S. Tavlas, 'What Have We Learned About Estimating the Demand for Money? A Multicountry Evaluation of Some New Approaches', International Monetary Fund Working Paper, February 1991.

Box, G.E.P., 'A General Distribution Theory for a Class of Likelihood Criteria', Biometrica, 36, 1949, 317-346.

Breeden, D., 'An Intertemporal Asset Pricing Model with Stochastic Consumption and Investment Opportunities', Journal of Financial Economics, 7, 1979, 265-296.

Breusch, T.S., 'Testing for Autocorrelation in Dynamic Linear Models', Australian Economic Papers, 17, 1978, 334-355.

Brueggeman, W.B., J.D. Fisher and D.M. Porter, 'Rethinking Corporate Real Estate', Journal of Applied Corporate Finance, 3, 1990, 39-50.

Buijink, W.F.J. and S.J. Maijoor, 'Entry and Exit, Market Share Mobility, and Seller Concentration in the Dutch Audit Market: 1968-1990', unpublished working paper, University of Limburg, April 1992.

Case, K.E. and R. Shiller, 'The Efficiency of the Market for Single-Family Homes', American Economic Review, 79, 1989, 125-137. 
Case, K.E. and R. Shiller, 'Forecasting Prices and Excess Returns in the Housing Markets", Journal of the American Real Estate and Urban Economics Association, $18,1990,253-273$.

Centraal Bureau voor de Statistiek, Statistiek der Hypotheken, 1983-1990.

Centraal Bureau voor de Statistiek, Staristiek Werkzame Personen, 1973-1991.

Chamberlain, G: and M. Rothschild, 'Arbitrage, Factor Structure, and Mean Variance Analysis on Large Asset Markets", Econometrica, 51, 1983, 1281-1304.

Chan, K.C., P.H. Hendershott and A.B. Sanders, 'Risk and Return on Real Estate: Evidence from Equity REITs', Journal of the American Real Estate and Urban Economics Association, 18, 1990, 431-452.

Cho, D.C., C.S. Eun and L.W. Senbet, 'International Arbitrage Pricing Theory:

An Empirical Investigation', Joumal of Finance, 41, 1986, 313-329.

Clauretie, T.M., 'The Impact of Interstate Foreclosure Cost Differences and the Value of Mortgages on Default Rates", Journal of the American Real Estate and Urban Economics Association, 15, 1987, 153-167.

Clauretie, T.M., 'Regional Economic Diversification and Residential Mortgage Default Risk', Journal of Real Estate Research, 3, 1988, 87-97.

Commission of the European Communities, 'Council Directive on Full Liberalization of Capital Movements L 178, June 24, 1988', Official Journal of the European Communities, July 8, 1988.

Conroy, M.E., "Alternative Strategies for Regional Industrial Diversification", Journal of Regional Sicience, 14, 1974, 31-46.

Conroy, M.E., "The Concept and Measurement of Regional Industrial Classification", Southern Economic Joumal, January 1975, 492-505.

Corgel, J.B. and G.D. Gay, "Local Economic Base, Geographic Diversification, and Risk Management of Mortgage Portfolios", Joumal of the American Real Estate and Urban Economics Association, 15, 1987, 256-267.

Darrat, A.F. and J.L. Glascock, 'On the Real Estate Market Efficiency', Journal of Real Estate Finance and Economics, 7, 1993, 55-72.

Eichholtz, P.M.A and N. Tates, 'Beleggen in Onroerend Goed in Nederland", Economisch Statistische Berichten, 78, 1993, 80-83.

Encyclopedia Britannica, fifteenth edition, The University of Chicago Press, Chicago, 
1991.

Engel, C. and A.P. Rodrigues, 'Tests of International CAPM with Time-varying Covariances', Journal of Applied Econometrics, 4, 1989, 119-138.

Engle, R.F. and C.W.J. Granger, 'Co-integration and Error Correction: Representation, Estimation, and Testing', Econometrica, 55, March 1987, 251-276.

Eurostat, Community Labour Force Survey, A User's Guide, 1988, Office for Official Publications of the European Communities, 1990.

Fama, E.F., 'Efficient Capital Markets: A Review of Theory and Empirical Work', Journal of Finance, 25, 1970, 383-417.

Fieleke, N.S., 'One Trading World, or Many: The Issue of Regional Trading Blocs', New England Economic Review; Federal Reserve Bank of Boston, May/June 1992 , 3-20.

Firstenberg, P.M., S.A. Ross and C.R. Zisler, "Real Estate: The Whole Story', Journal of Portfolio Management, Spring 1.988, 22-32.

Florence, P.S., Investment, Location, and Size of Plant, Cambridge, Cambridge University Press, 1948.

Friedman, H.C., 'Real Estate Investment and Portfolio Theory', Journal of Financial and Quantitative Analysis, 5, 1970, 861-874.

Garreau, J., The Nine Nations of North America, Pocket Books, 1985.

Gau, G.W., 'Public Information and Abnormal Returns in Real Estate Investment', Journal of the American Real Estare and Urban Economics Association, 13, 1985, 15-31.

Gau, G.W., 'Efficient Real Estate Markets: Paradox or Paradigm?', Journal of the American Real Estate and Urban Economics Association, 15, 1987, 1-12.

Gau, G.W. and A.P. Wicks, 'Impact of ARP and MURB Programs on the Vancouver Housing Market*, Study prepared for the Canada Mortgage and Housing Corporation, January 1982.

Geltner, D.M., 'Bias in Appraisal Returns', Joumal of the American Real Estate and Urban Economics Association, 17, 1989a, 338-352.

Gelttner, D.M., 'Estimating Real Estate's Systematic Risk from Aggregate Level Appraisal-Based Returns', Journal of the American Real Estate and Urban Economics Association, 17, 1989b, 463-481. 
Geltner, D.M., "A Further Examination of Appraisal Data and the Potential Bias in Real Estate Return Indexes: Comment and Clarification", Joumal of the American Real Estate and Urban Economics Association, 19, 1991, 102-112.

Geltner, D.M. "Estimating Market Values from Appraised Values without Assuming an Efficient Market'; unpublished working paper, University of Cincinnati, 1992.

Giliberto, S.M., 'A Note on the Use of Appraisal Data in Indexes of Performance Measurement", Joumal of the American Real Estate and Urban Economics Association, 16, 1988, 77-83.

Giliberto, S.M., 'Global Real Estate Securities: Index Performance and Diversified Portfolios", Salomon Brothers Bond Market Research; Real Estate, February 23, 1990a.

Giliberto, S.M., 'Equity Real Estate Investment Trusts and Real Estate Returns', Journal of Real Estate Research, 5, 1990b, 259-263.

Gilliberto, S.M., "Real Estate in the Portfolio: Then and Now", Salomon Brothers Real Estate Research, 1992.

Giliberto, S.M. and B. Testa, 'Global Property Share Performance by Geographic Region, Salomon Brothers Real Estate Research, August 21, 1990.

Godfrey, L.G., "Testing Against General Autoregressive and Moving Average Error Models When the Regressors Include Lagged Dependent Variables', Econometrica, 46, 1978, 1293-1302.

Gordon, J.N., 'European Real Estate's Place in a Portfolio', Baring Investment Property Bulletim, May 1991.

Gordon, J.N., "The Diversification Potential of International Property Investments', Real Estate Finance Joumal, Fall 1992, 42-48.

Goslings, J.H.W. and V.L.M.C. Petri, 'Beleggen in Onroerend Goed', Economisch Statistische Berichten, 1991, 932-935.

Granger, C.W.J., 'Developments in the Study of Cointegrated Economic Variables', Oxford Bulletin of Economics and Statistics, 48, 1986, 213-228.

Granger, C.W.J. and P. Newbold, Forecasting Economic Time Series, $2^{\text {nd }}$ edition, 1986, Academic Press, San Diego, 259-260.

Grauer, R.R. and N.H. Hakansson, 'Gains from Diversifying into Real Estate: 1955-1988 Portfolio Returns Based on the Dynamic Investment Model and the Empirical Distribution Approach', unpublished working paper, Haas School of Business, 
University of California, Berkeley, April 1992.

Grissom, T., J. Kuhle and C. Walther, 'Diversification Works in Real Estate, Too', Joumal of Portfolio Management, Winter 1987, 66-71.

Gros, D. and N. Thygesen, European Monetary Integration, from the European Monetary System to European Monetary Union, Longman, 1992.

Grubel, H.G., 'Internationally Diversified Portfolios', American Economic Review, 58, $1968,1299-1314$.

Grubel, H.G. and K. Fadner, 'The Interdependence of International Equity Markets', Journal of Finance, 26, 1971, 89-94.

Guntermann, K.L. and R. Smith, 'Efficiency of the Market for Residential Real Estate', Land Economics, 63, 1987, 34-45.

Guntermann, K.L. and S.C Norrbin, 'Empirical Tests of Real Estate Market Efficiency', Journal of Real Estate Finance and Economics, 4, 1991, 297-313.

Gyourko, J. and P. Linneman, 'Owner-Occupied Homes, Income-Producing Properties, and REITs as Inflation Hedges: Empirical Findings", Journal of Real Estate Finance and Economics, 1, 1988, 373-391.

Gyourko, J. and D.B. Keim, 'What Does the Stock Market Tell Us about Real Estate Returns?', Journal of the American Real Estate and Urban Economics Association, $20,1992,457-485$.

Hamada, R., J.M. Patell, R. Staelin and W.E. Wecker, 'The Role of Statistics in Accounting, Marketing, Finance, and Production', Journal of Business and Economic Statistics, 6, 1988, 261-272.

Hartzell, D.J., "Real Estate in the Portfolio', Salomon Brothers Real Estate Research, August 1986.

Hartzell, D.J., J. Hekman and M.E. Miles, 'Diversification Categories in Investment Real Estate', Journal of the American Real Estate and Urban Economics Association, 14, 1986, 230-254.

Hartzell, D.J., R. Pittman and D.H. Downs, 'An Updated Look at the Size of the U.S. Real Estate Market Portfolio", unpublished working paper, University of North Carolina, February 28, 1992.

Hartzell, D.J., D.G. Shulman, T.C. Langetieg and M.L. Leibowitz, 'A Look at Real Estate Duration', Journal of Portfolio Management, Fall 1988, 16-24. 
Hartzell, D.J., D.G. Shulman and C.H. Wurtzebach, 'Refining the Analysis of Regional Diversification for Income-Producing Real Estate', Journal of Real Estate Research, 2, 1987, 85-95.

Harvey, J., Urban Land Economics, The Economics of Real Property, second edition, Macmillan, London, 1987.

Hirshleifer, J., 'On the Theory of Optimal Investment Decision", Journal of Political Economy, 66, 1958, 329-352.

Hoesli, M.E. and M.S. Anderson, 'Swiss Real Estate: Return, Risk, and Diversification Opportunities", Journal of Property Research, 8, 1991, 133-145.

Hymer, S. and P. Pashigian, 'Turnover of Firms as a Measure of Market Behavior', Review of Economics and Statistics, 44, 1962, 82-87.

Ibbotson, R. and C.L. Fall, 'The U.S. Market Wealth Portfolio', Journal of Portfolio Management, Fall 1979, 82-92.

Ibbotson, R.G. and L.B. Siegel, 'Real Estate Returns: A Comparison with Other Investments', Journal of the American Real Estate and Urban Economics Association, 12, 1984, 219-242.

Ikeda, S., 'Arbitrage Asset Pricing under Exchange Risk', Journal of Finance, 46, 1991, 447-455.

International Monetary Fund (IMF), Exchange Arrangements \& Exchange Restrictions, Annual Report, 1986/1991.

International Monetary Fund (IMF), Direction of Trade Statistics Yearbook 1985/1991, Washington, 1992.

Jennrich, R.I., 'An Asymptotic $\chi^{2}$ Test for the Equality of Two Correlation Matrices', Journal of the American Statistical Association, 65, 1970, 904-912.

Judge, G.G., R.C. Hill, W.E. Griffiths; H. Lütkepohl and T.C. Lee, Introduction to the Theory and Practice of Econometrics, 1982, Wiley, New York, 321-323.

Kaplanis, E.C., 'Stability and Forecasting of the Comovement Measures of International Stock Market Returns', Journal of International Money and Finance, 7, 1988, 6375 .

Koedijk, C.G. and P.C. Schotman, 'Dominant Real Exchange Rate Movements', Journal of Intemational Money and Finance, 8, 1989, 517-531.

Kort, J.R. 'Regional Economic Instability and Industrial Diversification in the U.S.', 
Land Economics, 57, 1981, 596-608.

Kuhn, T.S., The Structure of Scientific Rewolutions, second edition, The University of Chicago Press, Chicago, 1970.

Lessard, D.R., 'International Portfolio Diversification: Multivariate Analysis for a Group of Latin American Countries', Journal of Finance, 28, 1973, 619-633.

Levy, H. and M. Samat, 'International Diversification of Investment Portfolios', American Economic Review, 60, 1970, 668-675.

Linneman, P., 'An Empirical Test of the Efficiency of the Housing Market", Journal of Urban Economics, 20, 1986, 140-154.

Lintner, J., 'The Valuation of Risk Assets and the Selection of Risky Investments in Stock Portfolios and Capital Budgets', Review of Economics and Statistics, 47, $1965,13-47$.

Liu, C.H., T.V. Grissom and D.J. Hartzell, 'The Impact of Market Imperfections on Real Estate Returns and Optimal Investment Portfolios', Journal of the American Real Estate and Urban Economics Association, 18, 1990, 453-478.

Liu, C.H., D.J Hartzell, W. Grieg and T.V. Grissom, "The Integration of the Real Estate Market and the Stock Market: Some Preliminary Evidence", Jourmal of Real Estate Finance and Economics, 3, 1990, 261-263.

Longin, F and B.H. Solnik, 'Is the Correlation in International Equity Returns Constant: 1960-1990?', working paper, HEC School of Management, 1993.

Lusht, K.M., 'The Real Estate Pricing Puzzle, Journal of the American Real Estate and Urban Economics Association, 16, 1988, 95-104.

Markowitz, H., "Portfolio Selection", Journal of Finance, 7, 1952, 77-91.

Markowitz, H., Portfolio Selection: Efficient Diversification of Investment, Wiley, New York, 1959.

McIntosh, W. and G.V. Henderson, 'Efficiency of the Office Properties Market", Joumal of Real Estate Finance and Economics, 2, 1989, 61-70.

Mehra, Y.P., 'In Search of a Stable, Short-Run M1 Demand Function', Economic Review, Federal Reserve Bank of Richmond, 78, May/June 1992, 9-23.

Mengden, A.E. and D.J. Hartzell, 'Real Estate Investment Trusts - Are They Stocks or Real Estate?', Salomon Brothers Real Estate Research, August 27, 1986. 
Merton, R.C., 'An Intertemporal Capital Asset Pricing Model', Econometrica, 41, 1973, $867-887$.

Merton, R.C., Continuous-Time Finance, Basil Blackwell, Cambridge, Massachusetts, 1990.

Miles, M.E. and D.J. Hartzell, 'Real Estate as an Asset Class: A 25-Year Perspective", Salomon Bothers Real Estate Research, 1988.

Miles, M.E., R. Pittman, M.E. Hoesli, P. Bhatnagar and D. Guilkey, 'A First Detailed Look at the Extent of America's Real Estate Wealth', unpublished working paper, University of North Carolina, May 3, 1991.

Nieuwland, F.G.M.C., Specularive Market Dynamics, An Econometric Analysis of Stock Market and Foreign Exchange Market Dynamics, Doctoral Dissertation, University of Limburg, the Netherlands, 1993.

Organization of Economic Cooperation and Development (OECD), Code of Liberalization of Capital Movements, March 1992.

Rayburn, W,, M. Devaney and R. Evans, "A Test of Weak-Form Efficiency in Residential Real Estate Returns', Journal of the American Real Estate and Urban Economics Association, 15, 1987, 220-233.

Ripley, D.M., 'Systematic Elements in the Linkage of National Stock Market Indices', Review of Economics and Statistics, 55, 1973, 356-361.

Ross, S.A., 'Arbitrage Theory of Capital Asset Pricing', Journal of Economic Theory, $13,1976,341-360$.

Ross, S. and R. Zisler, 'Risk and Return in Real Estate', Journal of Real Estate Finance and Economics, 4, 1991, 175-190.

Sharpe, W.F." "Capital Asset Prices: A Theory of Market Equilibrium under Conditions of Risk', Journal of Finance, 19, 1964, 425-442.

Shulman, D.G. and R. Hopkins, "Economic Diversification of Real Estate Portfollos" , Salomon Brothers Real Estate Research, 1988.

Solnik, B.H., 'An Equilibrium Model of the International Capital Market', Journal of Economic Theory, 8, 1974a, 500-524.

Solnik, B.H., 'Why not Diversify Internationally Rather than Domestically?', Financial Analysts" Journal, 30, 1974b, 48-54.

Solnik, B.H., 'International Arbitrage Pricing Theory', Journal of Finance, 38, 1983, 
449-457.

Steigenga, W., 'A Comparative Analysis and Classification of Netherlands Towns', Tijdschrift voor Economische en Sociale Geografie, June-July 1955, 105-118.

Stichting Gezamelijke Bemiddelende Organen, Nomen Gemeentegarantie voor een Hypothecaire Lening, 1992.

Sweeney, F.M., 'Investment Strategy, A Property Market Without Frontiers', Estates Gazetre, September, 1989, 21-30.

Tates, N. and P.M.A. Eichholtz, Beleggen in Vastgoed, Wolters Noordhoff, March 1993.

Tobin, $J_{*}$, 'Liquidity Preference as Behavior towards Risk', Review of Economic Studies, $25,1958,68-85$.

Webb, J.R. and J.H. Rubens, 'Portfolio Considerations in the Valuation of Real Estate' Journal of the American Real Estate and Urban Economics Association, 14, 1986, 465-495.

Webb, J.R. and J.H. Rubens, 'The Effect of Alternative Return Measures on Restricted Mixed-Asset Portfolios', Journal of the American Real Estate and Urban Economics Association, 16, 1988, 123-137.

Wurtzebach, C.H., 'Rationale for Domestic Pension Plans to Invest in Non U.S. Real Estate', International Real Estate Investing for U.S. Pension Funds, Volume X, Number 2.

Wurtzebach, C.H. and M.E. Miles, Modern Real Estate, fourth edition, Wiley, New York, 1991.

Zeekhauser, S. and R. Silverman, 'Rediscover Your Company's Real Estate', Hanvard Business Review, 1983, 111-117.

Zellner, A., 'An Efficient Method of Estimating Seemingly Unrelated Regressions and Tests for Aggregation Bias', Journal of the American Statistical Association, 57, $1962,348-368$.

Ziobrowski, A.J. and R.J. Curcio, 'Diversification Benefits of U.S. Real Estate to Foreign Investors', Journal of Real Estate Research, 6, 1991, 119-143. 


\section{Nederlandse Samenvatting}

Net als andere beleggers zijn ook beleggers in vastgoed geînteresseerd in het behalen van een zo hoog mogelijk rendement bij een gegeven risico. Het spreiden van risico, diversificatie, is daarbij een belangrijk hulpmiddel. In deze dissertatie staat diversificatie van onroerend goed centraal. Verschillende aspecten die van belang zijn voor de diversificatie van de vastgoedportefeuille worden hier empirisch bestudeerd.

Voor empirisch onderzoek naar vastgoed investeringen is de voornaamste hindernis dat vastgoed rendementen niet direct observeerbaar zijn. Dit wordt veroorzaakt door de heterogeniteit van vastgoed en het ontbreken van een openbare vastgoedmarkt, waar prijzen bekend worden gemaakt. Dit geldt in nog sterkere mate voor internationaal onderzoek naar vastgoed beleggingen. Aangezien deze dissertatie zowel internationaal als empirisch van aard is, is een belangrijke bijdrage ervan de exploratie van tot nu toe niet bestudeerde databronnen.

Dit geldt met name voor het eerste deel van de dissertatie, dat gericht is op regionale diversificatie van de vastgoedportefeuille. In deze benadering analyseer ik de economische samenstelling van regio's om tot efficiënte diversificatie van de vastgoedportefeuille te komen. Hiertoe maak ik gebruik van de verdeling van de werkgelegenheid over de verschillende economische sectoren binnen regio's, hetgeen een verband veronderstelt met de vraagzijde van de vastgoedmarkten. De intuittie is hier dat vastgoed rendementen in regio's die dezelfde economische samenstelling hebben, positief met elkaar correleren. Dit zal met name gelden als de aanbodsituatie op de regionale vastgoedmarkten overeen komt. Aan de andere kant, als regio's economisch van elkaar verschillen, dan zullen zowel de werkgelegenheidscijfers als de vastgoed rendementen lage of negatieve correlaties vertonen. Risicospreiding kan dus worden bereikt door een portefeuille samen te stellen met vastgoed in zulke gebieden.

Hoofdstuk 2 past deze benadering toe op Europese vastgoed portefeuilles. Met behulp van een aangepaste chi-kwadraat toets worden 74 Europese regio's geclassificeerd als divers of gespecialiseerd. De bevindingen geven aan dat 
regio's met dezelfde economische specialisaties verspreid zijn over Europa. Dat betekent dat investeringen die regionaal gespreid zijn, niet noodzakelijkerwijs ook economisch gespreid zijn. Optimale spreiding van de vastgoedportefeuille is dus niet te bereiken door naileve regionale spreiding alleen. Daarvoor is het van belang de economische karakteristieken van de regio's waarin belegd wordt met elkaar te vergelijken. Echter, niet alle regio's kennen een economische specialisatie. Veel regio's hebben een gediversifieerde economie, en onroerend goed in die regio's is waarschijnlijk minder risicovol dan in gespecialiseerde regio's.

In hoofdstuk 3 ontwikkel ik een aantal indicatoren van regionale economische diversiteit en stabiliteit, die ik gebruik als verklarende variabelen van onroerend goed risico. De veronderstelling is dat onroerend goed in gediversifieerde en stabiele regio's een relatief laag risico kent. Opnieuw zijn de indicatoren gebaseerd op werkgelegenheidscijfers, maar in dit hoofdstuk gebruik ik alleen data voor Nederland, wat betekent dat ik de analyse op een meer gedesaggregeerd niveau kan uitvoeren dan in hoofdstuk 2 het geval was. Ik onderzoek in hoeverre de geconstrueerde indicatoren een verklaring geven van hypotheek-faillissementen. Hiertoe maak ik gebruik van een dataset die de populatie van Nederlandse, tussen 1976 en 1990 gefailleerde hypotheken met een overheidsgarantie omvat.

De conclusies van hoofdstuk 3 zijn dat dynamische maatstaven van economische stabiliteit een betere verklaring geven voor hypothecair risico dan statische maatstaven van economische diversiteit. Nederland kent een vorm van hypotheekgarantie waarbij de hypotheekgever (de geldlener) geen premie betaalt. Het risico wordt gedragen door de overheid. $\mathrm{Er}$ is echter discussie gaande over het introduceren van premies. De resultaten van dit onderzoek geven aan dat regionale economische karakteristieken dienen worden meegenomen in het bepalen van de eventueel in te voeren premies. De voornaamste bijdrage van dit hoofdstuk is echter dat de relatie tussen de vastgoedmarkt en regionale werkgelegenheidscijfers, die in hoofdstuk 2 verondersteld werd, hier wordt aangetoond. Dit betekent dat gebruikmaking van regionale werkgelegenheidscijfers als basis voor de diversificatie van vastgoedportefeuilles inderdaad tot betere resultaten leidt dan naïeve regionale diversificatie.

In het tweede deel van deze dissertatie worden rendementen van vastgoed 
aandelen gebruikt om ideeën te toetsen die te maken hebben met internationale diversificatie van vastgoedportefeuilles. In hoofdstuk 4 onderzoek ik eerst de gebruikte rendements-indices van vastgoed aandelen. Ik onderzoek of deze rendementen zich gedragen als aandelenrendementen of meer als de rendementen van andere bekende indices, met name indices die zijn gebaseerd op taxaties. Het verband tussen vastgoed aandelen en de aandelenmarkten wordt hier voor 12 landen onderzocht met behulp van een standaard marktmodel. Behalve voor $Z$ witserland vind ik voor al deze landen dat de aandelenmarkt de rendementen van vastgoedaandelen significant verklaart. Dit betekent dat het diversificatie potentieel van het introduceren van vastgoed in een internationale aandelenportefeuille niet groot is. Een andere bevinding is dat de beta's van vastgoed per continent verschillen. De beta's zijn het hoogst in het Verre Oosten, en lager in Europa en Noord Amerika. Dit kan in ieder geval gedeeltelijk worden verklaard door verschillen in huurcontracten tussen deze drie continenten.

Desalniettemin gedragen vastgoed aandelen zich ook als vastgoed. In hoofdstuk 4 onderzoek ik voor 4 landen de relatie tussen vastgoed aandelen en taxatiegebaseerde rendementen met behulp van coïntegratie modellen. De resultaten geven aan dat rendementen op vastgoed aandelen een significante voorspelling geven van taxatie-gebaseerde rendementen. Dit betekent dat gebruikmaking van vastgoed aandelen als een benadering voor vastgoedrendementen economisch zinvol is. Voor onderzoek naar de internationale aspecten van het beleggen in vastgoed is dat van groot belang, omdat rendementsgegevens van vastgoed aandelen beschikbaar zijn voor veel meer landen dan alleen die waarvoor taxatie-indices beschikbaar zijn.

In het volgende hoofdstuk, hoofdstuk 5, ga ik dieper in op de eerder genoemde continentale verschillen tussen rendementen op vastgoed aandelen. Ik onderzoek continentale factoren die vastgoedrendementen bepalen. Het bestaan van zulke factoren is plausibel omdat kapitaal, goederen en diensten zich vaak gemakkelijker verplaatsen binnen continenten dan tussen continenten. Dit betekent dat tussen landen liggende in eenzelfde continent gelijktijdige bewegingen van zowel de vraag als het aanbod van vastgoed te verwachten zijn. Te verwachten is dat deze bewegingen dan ook zichtbaar zijn in de rendementen op dat vastgoed. Om de continentale vastgoedfactoren te bestuderen ontwikkel en gebruik ik een nieuwe vorm van principale componenten analyse. Deze methode heeft het voordeel dat de gevonden componenten onafhankelijk zijn van de keus van 
de muntsoort waarin de analyse wordt gedaan. Dit is belangrijk omdat de resultaten hierdoor relevant worden voor investeerders uit alle landen.

In de empirische analyse van hoofdstuk 5 vind ik de verwachte continentale factoren in vastgoed rendementen. Vastgoedmarkten blijken internationaal gesegmenteerd te zijn langs grenzen van continenten. Vastgoed rendementen in het Verre Oosten vertonen vergelijkbare bewegingen, en ditzelfde geldt voor Europa en Noord Amerika. Uitzonderingen zijn Japan en het Verenigd Koninkrijk. Japans vastgoed vertoont geen overeenkomsten met ander vastgoed, of dat nu in het Verre Oosten is of niet. Brits vastgoed, daarentegen, toont gelijkenis met zowel Europees vastgoed als vastgoed in het Verre Oosten. Deze resultaten betekenen dat een intercontinentale benadering noodzakelijk is om tot optimaal gediversifieerde vastgoedportefeuilles te komen. Met investeringen in slechts eén continent kan van optimale risicospreiding geen sprake zijn. De andere belangrijke bevinding in dit hoofdstuk is dat de componenten structuur van de vastgoed rendementen grotendeels onafhankelijk is van de beslissing de portefeuille al dan niet tegen valutarisico af te dekken. Valutarisico speelt een ondergeschikte rol in het totale risico van internationale vastgoed beleggingen.

Hoofdstuk 6, het laatste empirische hoofdstuk van deze dissertatie, onderzoekt de internationale covariantiestructuur van rendementen op vastgoed aandelen. Portefeuillemodellen, die gebruikt worden om efficiënte internationale allocaties van beleggingen te genereren, vereisen als imput schattingen van de variantiecovariantie structuur van die beleggingen. Doorgaans wordt hiervoor de gerealiseerde structuur gebruikt. De uitkomsten van het gebruikte model zijn dan alleen zinvol als de variantie-covariantie structuur stabiel is in de tijd. In hoofdstuk 6 toets ik of dit het geval is voor vastgoed aandelen. De verwachting is, dat dit niet het geval is, omdat rendementen op vastgoed aandelen in ieder geval gedeeltelijk worden beïnvloed door de nationale onroerend goed markten, die niet synchroon bewegen. Deze verwachting wordt in de formele toetsen gestaafd. Covarianties zijn inderdaad niet stabiel, terwijl correlaties stabiel zijn tussen sommige tijdsintervallen, en niet stabiel tussen andere. Deze resultaten betekenen dat het gebruik van standaard portefeuille modellen voor het bepalen van de internationale allocatie van vastgoed niet gerechtvaardigd is. 


\section{Curriculum Vitae}

Piet M.A. Eichholtz is op 6 december 1962 geboren te Bloemendaal. In 1982 slaagde hij voor het eindexamen Atheneum, waarna hij Economie ging studeren aan de Universiteit van Amsterdam. Na het behalen van het doctoraaldiploma Economie in 1988 vervulde hij zijn vervangende dienstplicht bij de sectie Financiering van de Rijksuniversiteit Limburg. In januari 1990 werd hij assistent in opleiding bij dezelfde sectie, waar hij werkte aan een onderzoek waarvan dit proefschrift het resultaat is. Van oktober 1989 tot en met september 1992 was hij tevens werkzaam bij de staf Strategische Beleidsontwikkeling Beleggingen van het Algemeen Burgerlijk Pensioenfonds (ABP). In de zomer van 1991 was hij Visiting Scholar aan de Kenan-Flagler Graduate School of Business van de University of North Carolina, Chapel Hill. Vanaf januari 1994 zal hij als Postdoctoral Research Fellow verbonden zijn aan het Limburg Institute of Financial Economics van de Rijksuniversiteit Limburg.

Piet M.A. Eichholtz, born December 6th 1962 in Bloemendaal, studied Economics at the University of Amsterdam from 1982 until 1988. After receiving his Master's degree in Economics in October 1988, he joined the Department of Finance of the University of Limburg, where he completed this doctoral dissertation. Between October 1989 and September 1992, he also worked for the Strategic Investment Policy Group of the Algemeen Burgerlijk Pensioenfonds (ABP). In the summer of 1991, he was a Visiting Scholar at the Kenan-Flagler Graduate School of Business of the University of North Carolina at Chapel Hill. Starting in January 1994, he will be a Postdoctoral Research Fellow at the Limburg Institute of Financial Economics of the University of Limburg. 